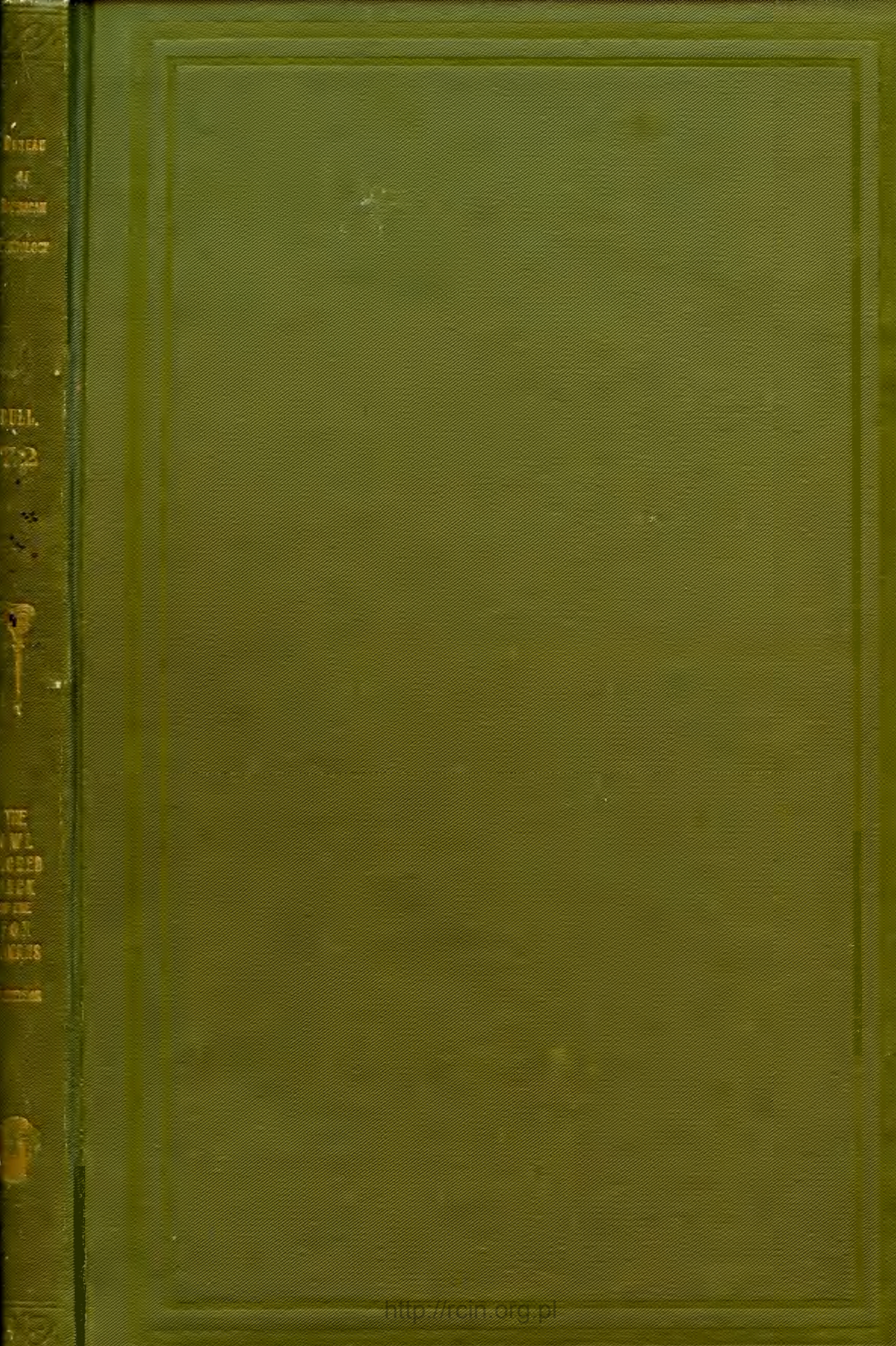




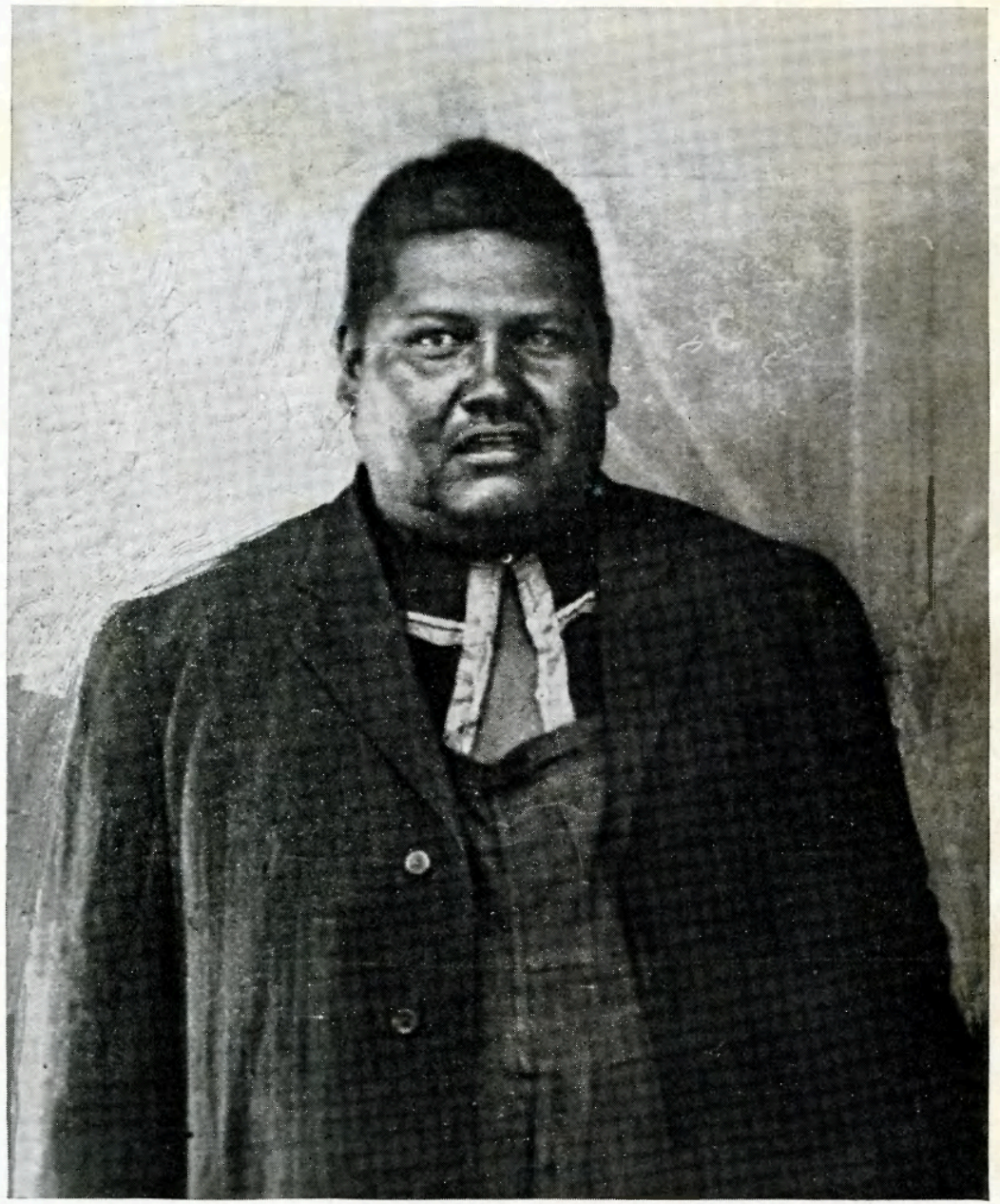

ALFRED KIYANA, OWNER OF THE SACRED PACK 
SMITHSONIAN INSTITUTION

BUREAU OF AMERICAN ETHNOLOGY

BULLETIN 72

\section{THE OWL SACRED PACK OF THE FOX INDIANS}

BY

\section{TRUMAN MICHELSON}

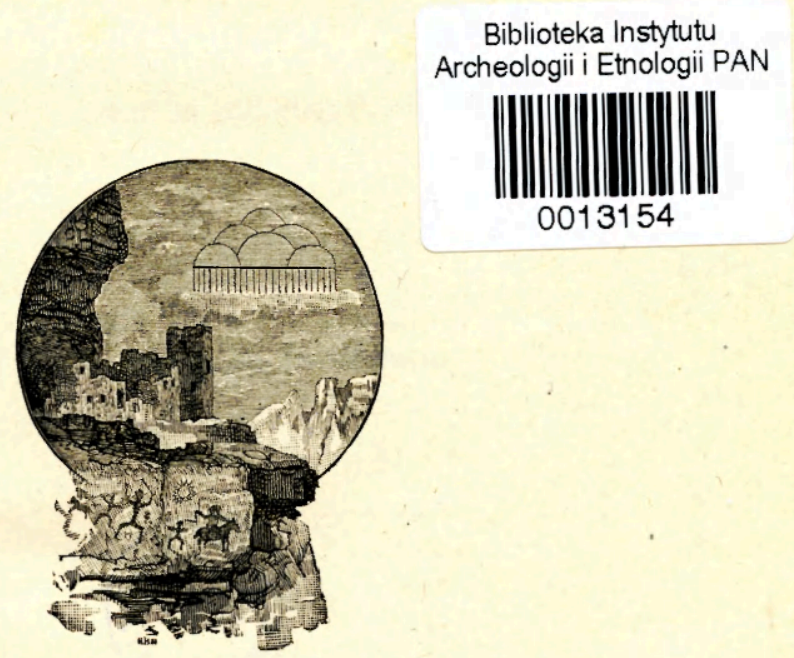

WASHINGTON

GOVERNMENT PRINTING OFFICE 


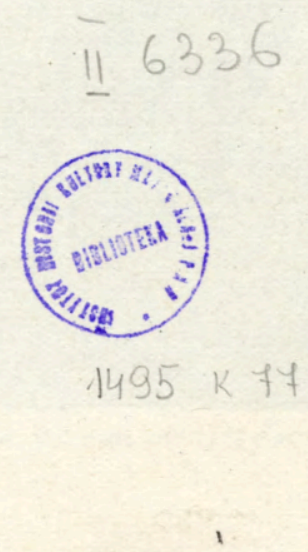

$2 k c .116 / 75 \mathrm{~K}$ 


\title{
LETTER OF TRANSMITTAL
}

\author{
Smithsonian Institution, \\ Bureau of American Ethnology, \\ Washington, D. C., July 11, 1919.
}

Sir: I have the honor to submit herewith an article on "The Owl Sacred Pack of the Fox Indians," by Truman Michelson, and to recommend its publication as Bulletin 72 of the Bureau of American Ethnology.

Respectfully,

J. Walter Fewkes,

Chief.

Dr. Charles D. Walcott, Secretary of the Smithsonian Institution. 
http://rcin.org.pl 


\section{CONTENTS}

Introduction.

Ethnological importance of this text.

Fox phonetics

The owl sacred pack:

Indian text

English translation

Some linguistic notes on the text. 


\section{ILLUSTRATIONS}

Plate 1. Alfred Kiyana, owner of the sacred pack ............. Frontispiece.

2. Diagram showing performance of dance................... 84

3. Wrappings of the owl sacred pack ...................... 84

4. Contents of the owl sacred pack......................... 84 
hțtp://rcin.org.pl 


\section{THE OWL SACRED PACK OF THE FOX INDIANS}

\section{By Truman Michelson}

\section{INTRODUCTION}

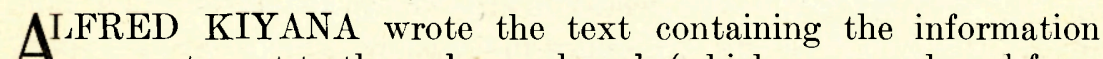
A appurtenant to the owl sacred pack (which was purchased from him by me in the spring of 1914 for Dr. Boas; it is now in the Berlin Museum für Völkerkunde) in the current syllabary. I subsequently restored this according to the phonetics of Edward Davenport, with the exception of the songs, which are given as pronounced by Alfred Kiyana. The translation is based on an English version by Horace Poweshiek, corrected and supplemented by a grammatical analysis of the text by myself. ${ }^{1}$ The meanings of the songs, however, are given as explained by Alfred Kiyana.

That the pack is genuine is certain by what I know of the contents of other Fox packs. That the information given in connection with it is authentic is shown by the fact that the myths and folk tales which I have obtained from Alfred Kiyana (such as those of Wi'ss 'kä'A', the Apaiyā' ${ }^{\prime} i^{\prime} \mathrm{Ag}^{\mathrm{ki}}$, Wâpa'sai ${ }^{\mathrm{yA}}$, the one whose father was the Sun, the Origin of the Months, the Bear and the Wife, the Youth who fasted too long and became a fish, Feather, Pìtci ${ }^{\prime} \bar{a}^{{ }^{*}{ }^{*}}{ }^{\circ}$, Fox and Wolf) have checked up exceedingly well with corresponding ones obtained from other informants; as has the ethnological information (on gentile organization, the tribal dual division, marital and mortuary customs and observances, and ceremonial organization) obtained from him. Moreover, the kind of information given in the present text is much the same as that given by other informants regarding other packs. Lastly, Edward Davenport vouches for its authenticity.

The translation of the text has been made as literal as possible without violence to English idiomatic usage, as my plan has been to make this volume serviceable not only to ethnological but also to linguistic students. No interlinear translation has been added, as three specimens of Fox interlinear texts have been published; and owing to the genius of Algonquian languages interlinears are typographically awkward. However, the list of stems occurring in the text is practically exhaustive; so that the serious student should have no difficulty in working out the Indian text.

1 This task was materially lightened by the intelligent assistance rendered by both Edward Davenport and Harry Lincoln. 
I may add that the works of Watkins and Lacombe on Cree, Cuoq on Algonkin, and Baraga on Chippewa have more than once been of great service to me in working out both the translation and the list of stems, as have also the works of Jones on Fox.

The punctuation of the Indian text and the English translation has been made to correspond as closely as possible. The only essential point to note is that it has not always been feasible to make the commas correspond.

The paragraphing (which is the same in both) has been done largely with a view to English usage. However, it has often been possible to take advantage of the well-known feature of Algonquian languages that identity and difference in third persons are kept apart by means of grammatical devices.

The text, as stated above, was written out by Alfred Kiyana in the current syllabary, on which see Jones in the Boas Anniversary Volume, pages 88-93. It was subsequently dictated a couple of times by Edward Davenport, and thus phonetically restored by me. The second dictation was in order to correct spelling-pronunciations, as the Fox are not accustomed to read letters or other documents written in the current syllabary aloud. When they first attempt it they are very apt to read the syllables with conventionalized values, thus $l a, l e, l i, l_{0}$ as $p \bar{a}, p e, p \bar{c}, p \bar{o}$, irrespective, of the fact that these values are likely to be wrong in any given instance, for $l a$, etc., may equally well represent $p_{A}, p \bar{a}, p i, p u$, as well as other alternatives. I had previously trained Edward Davenport to read nearly correctly; and with the second dictation blemishes arising in this manner have, I think, been practically eliminated. A few visual errors have been corrected by me.

There is another source of error which may occur in restoring a text dictated from a manuscript written in the current syllabary, and one difficult to control, namely, owing to the deficient phonetic character of the syllabary homographs may occur; that is, a word in the syllabary may be capable of two distinct phonetic restorations both equally justifiable but with entirely different meanings; and the wrong word may be dictated. An example is a ya ga te $k i$, which may be equally well aiy $\bar{a}^{\prime} k w \bar{a} t \ddot{a} g^{k i}$ " "as far as light goes," or aiy $\bar{a}^{\prime} g w a t \ddot{a} g^{k i}$ " "in a pile." Fortunately homographs are not very frequent. It may be noted that a second dictation will not always remove blemishes of this nature; the word cited above was twice dictated with the wrong value. A grammatical analysis and the context are the only safe correctives to eliminate defects of this character.

If I have spent much space in pointing out errors which are liable to occur in recording texts dictated from manuscripts written in the current syllabary, it is because they have hitherto been ignored. At the same time I am firmly convinced that more idiomatic texts and 
in better literary style may be obtained by using this method than by dictation without a manuscript.

For general information on the Fox Indians see Michelson, Journal of the Washington Academy of Sciences, 9, 483-494; 521-528; $593-596$.

\section{E'THNOLOGICAL IMPOR'TANCE OF THIS TEX'T}

On a former occasion (Journal of the Washington Academy of Sciences, 6, 209) I laid emphasis on the value of ritualistic origin myths for strictly ethnological purposes. For it is patent that in bulk we have reflections of what actually takes place to-day, or did until very recently. Moreover, the former owner of the owl sacred pack is now dead, and the pack itself is in the Museum für Völkerkunde at Berlin. The present text therefore contains all the information available on this pack. Incidentally we obtain a good deal of data on Fox ethnology.

The text starts out with a general description of how a gens festival is conducted; and it will be noticed that my contention that

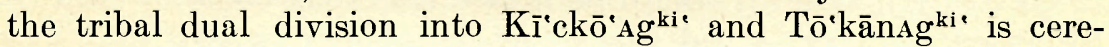
monial as well as for purely athletic purposes is sustained. Other information given is that after the words $\bar{o}^{\prime} n \bar{o}^{\prime} d t c^{i *}$ (on which see William Jones, Fox Texts, 337, footnote 1) are pronounced conversation ceases. If a baby cries the mother will take the child home, and divest herself of her finery. The account of the winter ceremony is given more succinctly (p. 19). The suitable foods are mentioned; and the manner of disposing of the bones is referred to: in the winter ceremony they are to be burned; when a dance is given in combination with the gens festival (which will only be in summer) they are thrown far away at the foot of an oak tree on the north side, where no sunlight will strike them.

The use of the sacred pack in warfare is duly explained (p. 19 and following); a brief description of the ceremony preceding a war party is given. Next we are told the various songs - the dancing, the eating, and the medicinal ones. Further directions (p. 27) now follow regarding the ceremonies appurtenant to this sacred pack; and the foods to be eaten are again touched on. Still further instructions on how the ceremony is to be conducted follow (p. 27). The wailing songs are then given. Some brief information regarding the disposal of the dead succeeds.

The properties of the medicine contained in the pack are next described (p. 29). General medical procedure follows in turn.

Procedure on the warpath is now given; and the marvelous powers of the medicine in the pack in causing death, and the effect of the sound of the flute on the enemy are duly recorded. Instructions are given as to ceremonies if hard-pressed by the enemy or if the enemy is about to escape: wide rivers can be made narrow by the mystic power of the contents of the pack. 
The life of the one blessed ("taken pity on" is a closer rendition of the Indian original) is obviously a reflection of what is expected of a man who introduces ceremonials. An account of his meeting the owl, together with his own niece, is given (p. 37), and we are told the blessings which the owl bestows: he will be able to cross deep and wide rivers without obstruction and be able to heal the wounded. Then elaborate instructions and injunctions follow. The one blessed will have knowledge of the future. Further instructions succeed.

The sacred pack is "found," and a gens festival is held. The efficacy of the pack is shown by the blind being made to see, the crippled to walk, etc. The afflicted are led around in a circle four (a ceremonial number) times, and thus made well. The people are told that the one blessed and his niece do not alone own the pack but that all of his gens also own it. A long exhortation now follows (pp. 53-56).

The power of Black-Rainbow is shown upon his capture by the Sioux (p. 61). On his return he makes the Sioux come by beating his drum. All are killed save a woman who is spared and sent home to tell the story of what happened to the Sioux. (For a similar custom among eastern Algonkins see Speck, International Journal of American Linguistics, 1, 208, footnote 1.) A curse of death is pronounced upon her in case she disobeys the mandate. Further exploits of Black-Rainbow are now narrated. A captured Sioux man is sent home with injunctions as above. The gift of foresight is shown by Black-Rainbow in foretelling his own end. The turning to stone of Black-Rainbow and his niece follows. This last episode, it may be added, occurs in other sacred narratives of this nature.

In conclusion it may be stated that more information is given in the present text regarding a Fox sacred pack than has hitherto been published on any Fox pack or packs.

\section{FOX PHONETTCS}

I have discussed the phonetic elements of Fox in the International Journal of American Linguistics, i, 54, and the Journal of the Washington Academy of Sciences, 9, 521-525.

The following is a tabular view of the phonetic elements as I conceive them:

\section{Vowels and Diphthongs}

Full-sounding:

$\begin{array}{llllll}\mathbf{a} & \mathbf{A} & \mathrm{e} & \mathrm{i} & \mathrm{o} & \mathrm{u} \\ \overline{\mathbf{a}} & \hat{\mathbf{a}} & \ddot{a} & \overline{\mathrm{e}} & \overline{\mathbf{i}} & \overline{\mathrm{o}} \\ \text { ai } & \mathrm{au} & & & & \end{array}$

Voiceless and aspirated (terminal only): A. es is ue 


\section{Consonants}

\begin{tabular}{|c|c|c|c|c|c|}
\hline & Stops. & Spirants. & Afiricatives. & Nasals. & Semi-vowels \\
\hline Glottal.. & $\varepsilon$ & . & - & - & - \\
\hline Palatal... & $\mathrm{k} \cdot \mathrm{kg} \mathrm{g}^{\mathrm{k}}$ & - & - & - & $y^{y}$ \\
\hline Alveolar.. & - & $c^{*} \mathrm{c}$ & $\mathrm{tc}{ }^{\circ} \mathrm{tc}{ }^{\mathrm{d}} \mathrm{tc}$ & - & - \\
\hline Dental............ & $t \cdot t d$ & $\mathrm{~s}$ 's & - & $\mathrm{n}^{\mathrm{n}}$ & - \\
\hline Labial... & $\mathrm{p} \cdot \mathrm{p} b$ & - & - & $\mathrm{m}^{\mathrm{m}}$ & $\mathrm{w}^{\mathrm{w}}$ \\
\hline
\end{tabular}

Following the recommendations of the committee of the American Anthropological Association (see p. 1 of Phonetic Transcription of Indian Languages, Smithsonian Miscellaneous Collections, vol. 66, No. 6), I have employed the symbols and general scheme of Dr. Jones save where, in my judgment, they are inadequate.

Owing to the fact that the Fox language has "sentence-phonetics," and that the number of words I could record at a time depended on the length of the words, the resulting text, of course, contained mixed phonetics. It has on the whole seemed best to normalize the sentence-phonetics so as to give a truer picture of the language. In this normalization I have substituted full-sounding vowels for the voiceless aspirated ones before initial consonants, save where the sense indicates a pause; before initial vowels and ai- the preceding terminal vowels are eliminated. In this way complicated symbols such as $-\mathrm{m}^{\mathrm{ma}}$, $-\mathrm{g}^{\mathrm{kWA}^{*}}$ have for the most part been eliminated in iavor of $-\mathrm{mA}$, -gwa respectively. Of course this normalization has not been rigidly adhered to, for the Foxes themselves are not entirely consistent in it, being guided to some extent by the tempo. Final vowels are aspirated before initial sibilants. On the other hand, it was not possible to normalize the sentence and word accent; so that this text is "mixed" to this extent. I have followed the dictator in this respect. The point is practically confined to trisyllabic and quadrisyllabic words. When words are given by themselves outside of a sentence ordinarily the penult is accented. Jones's Fox Texts are unácented.

Another point may be properly brought up here, namely, the treatment of final $i$ of one morphological unit before another such unit beginning with a vowel or diphthong. The elision of this varies among different speakers; and is also dependent on the tempo. I have followed the usage of the dictator in this respect. The glottal stop is merely rhetorical.

In conclusion it may be noted that Edward Davenport does not pronounce aspirations before initial vowels and ai, save rhetorically. 


\section{THE OWL SACRED PACK}

\section{INDIAN TEXT}

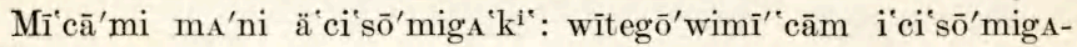
$\mathrm{t}^{\mathrm{wi}}$.

Kìgä'nugini nī'miwag i' kwäwagi nā'ka'dtci ne'niwagkie. Negutiwấ "säyāwe nyäwe'nwi nī'miwagki". Nīgā'niwagi ne's ${ }^{\text {wi }}$, negu't

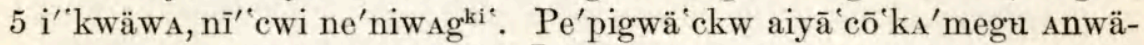

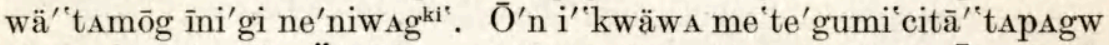

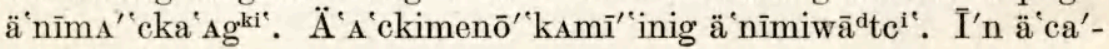
wiw $\bar{a}^{\mathrm{d}} \mathrm{tc}^{\mathrm{i}}$.

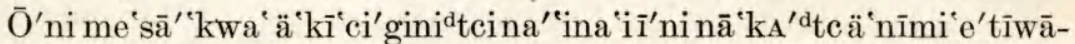

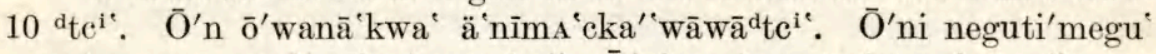

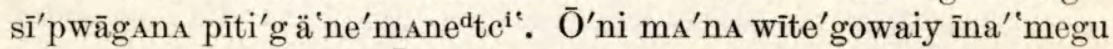

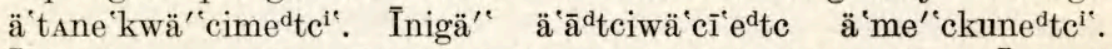
Inina 'megu me ${ }^{\prime \prime}$ tenō'i wä'cī'edtei nīpe'nigini, à'gwi nō'ta. Inina'-

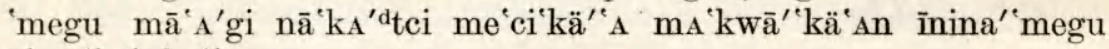
15 ä wä̈'cīe $e^{d} t c^{i}$.

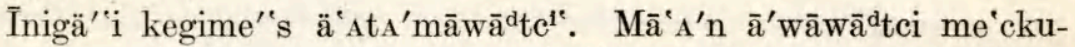
'pwā'ganani me'sōtäwe'megu-mōtci'megu a'peno' atA'mä āp ${ }^{i}$,

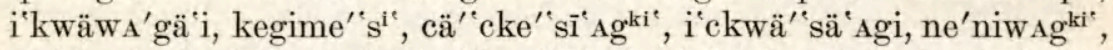

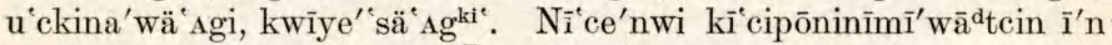

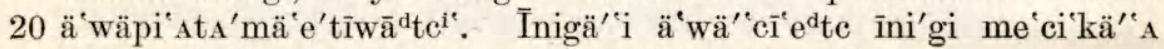

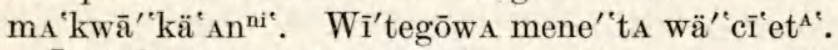

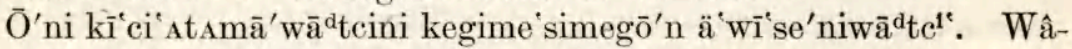

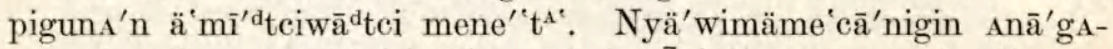

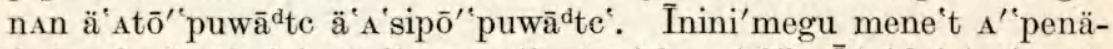

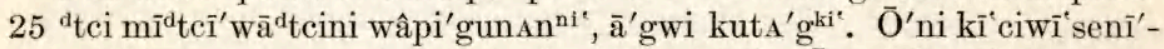

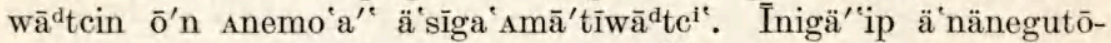

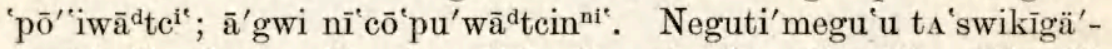

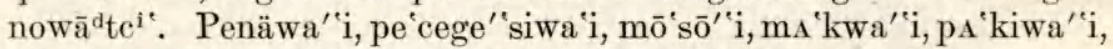

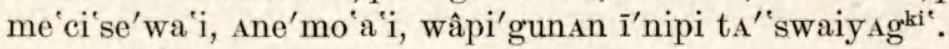

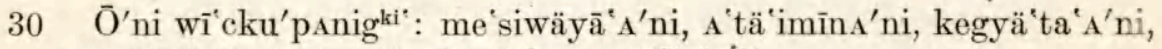

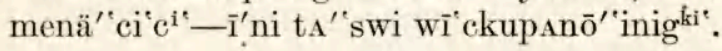

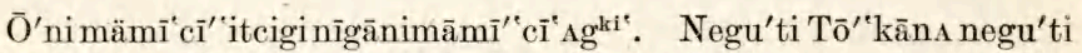

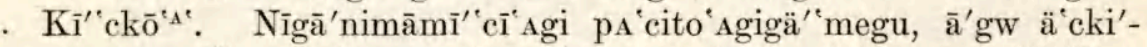

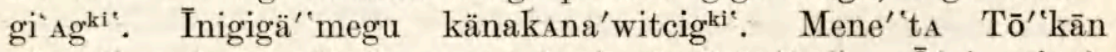

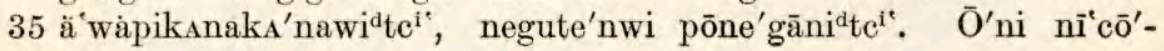




\section{THE OWL SACRED PACK}

\section{ENGLISH TRANSLATION}

The way this sacred pack is called: it is called an owl sacred pack.

At gens festivals women and men dance. In one day they dance four times. There are three leaders, one woman and two men. Those men alternately blow the flute. And the woman has an oak leaf fastened in her hair. In early spring is when they dance. That is what they do.

And when the corn ears are mature they dance together again. Then they fasten corn tassels in their hair. Then one cornstalk is fixed upright inside (the lodge). And this owl skin is placed with his head toward it. And then it is repainted red. The only time when it is painted is in the harvest time, not before or after. Then indeed these are likewise painted, to wit, the snapping turtle and tortoise.

All smoke at the time. This catlinite pipe is what each and every one uses-even a child, or a woman is given a smoke-all, maidens, little girls, men, youths, boys. After they have ceased dancing for the second time is when they begin to be given a smoke together. Then, moreover, is when these, the snapping turtle and tortoise, are painted. The owl is the first to be painted.

Now after all have smoked, they dine. Pumpkins are what they eat first. They use four large bowls and always eat in groups. These pumpkins are what is always eaten first, no other thing. Then after they have eaten, they serve dogs to each other. At that time, it is said, they always eat singly (i. e., each out of one bowl); two do not eat together. $A$ s many as are celebrating the gens festival (have) an individual (bowl). Turkeys, deer, moose, bears, partridges, prairie chickens, dogs, pumpkins are said to be the total number of things (permitted to be eaten).

Now as to the sweet things (to be eaten): maple-sugar cakes, strawberries, hazelnuts, maple syrup-such is the number of sweet things.

Now as to the ceremonial attendants who are the head ceremonial

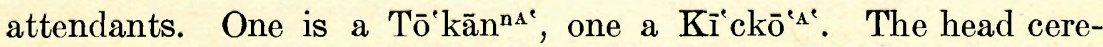
monial attendants are indeed old men, not young men. Those, indeed, are those who will make the speeches. First the Tō"kānns" begins to speak at length, it is after they have ceased dancing for 


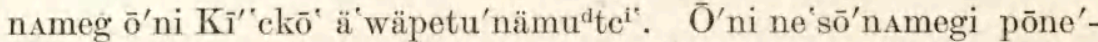

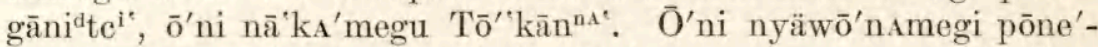

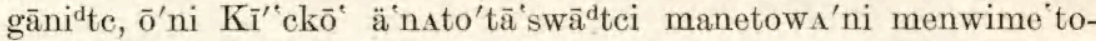
'sänenī'wiwen ${ }^{\text {ni' }}$.

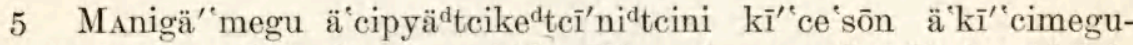

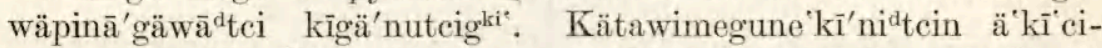

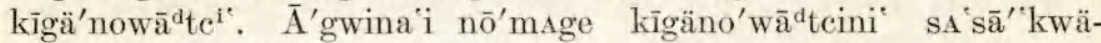
"WAgki'. Wïne'kīnidtci kī'ce'sōn ${ }^{\mathrm{ni}}$.

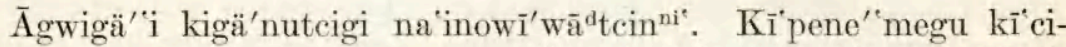

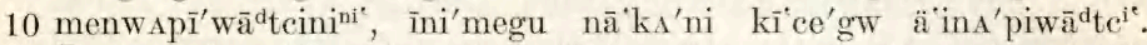

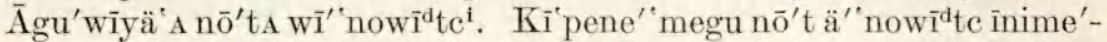

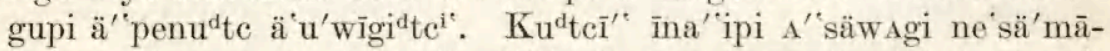

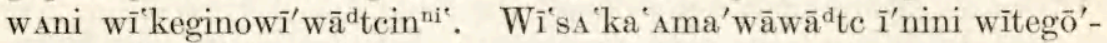
waiysn ${ }^{n i}$. Me 'tenō' 'megupi kä'te 'sí' 'itcigi me ce'na' änemi'aiyāpA-

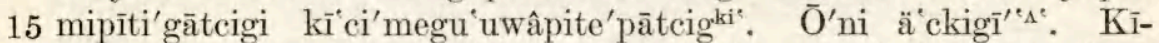
'pene' megu nwäwī'wā ${ }^{\top} t c i n$ äpenowādtci'megu. SA'sā'kwäwA'gipi

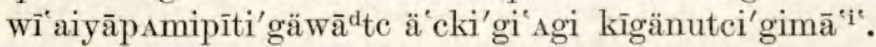

$\bar{O}^{\prime}$ ni wī'ku'meteigi me tenō' ${ }^{\prime \prime}$ megu wäpikanakanawi'nidtcini mämī' ceä'a ä äpōnino'wīwădtc ${ }^{\mathrm{i}}$.

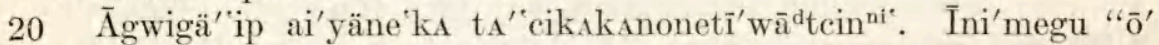

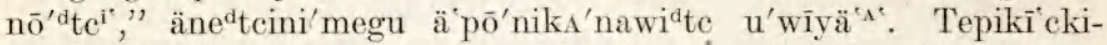

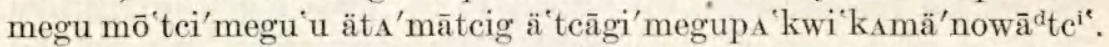

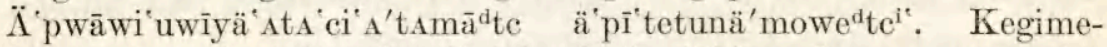

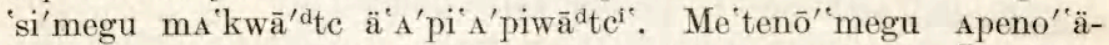

25 'Agi tcatcawī'ipi ta 'cimai'yōwag ätanetunä'mowe ${ }^{\mathrm{d}} \mathrm{cc}^{\mathrm{i}}$. Inipā'pe-

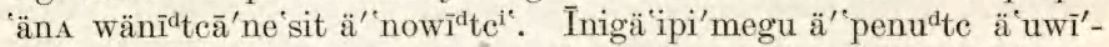

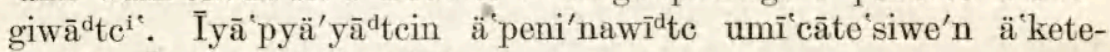
nagki. $\bar{I}^{\prime \prime n i p ~ a ̈ c a ' w i w a ~} \bar{a}^{\mathrm{d}} \mathrm{te}^{\mathrm{i}^{\mathrm{i}}}$.

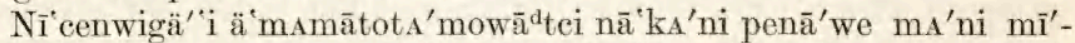

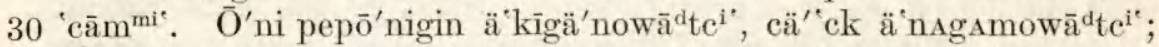

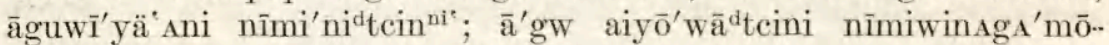

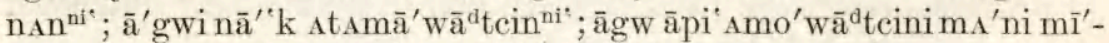

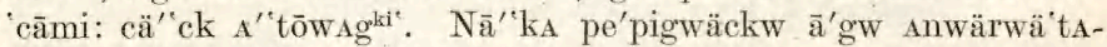

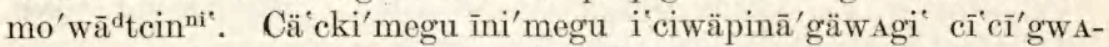

35 nani cä'ck anwäwä 'sA'tōwAgki'; ō'n äpwāwi'Anwäwä'wāwādtci

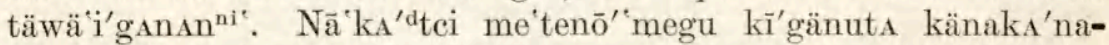

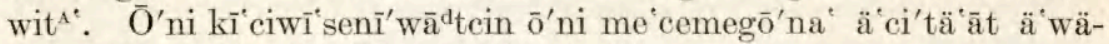

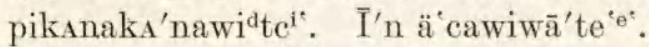

I'kwäwagi' cä'cki nā'ku'gätagki'. Me cewīna ${ }^{d} t c \bar{a}^{\prime}$ 'megu ä ci'tä-

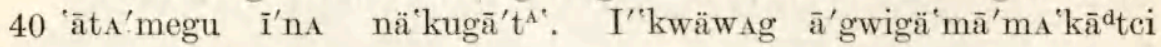


the first time. Then the second time, the $\mathrm{Ki}^{\mathrm{i}} \mathrm{ck} \overline{\mathrm{o}}^{{ }_{\mathrm{A}}{ }^{\cdot}}$ begins to speak. Then after they have ceased dancing for the third time, again the Tón $k \bar{a} n^{n \Delta^{*}}$. And after they have ceased dancing for the fourth time, then the $\mathrm{K}^{\mathrm{i}} \mathrm{ck}^{\mathrm{o}}{ }^{{ }^{\mathrm{A}} \mathrm{A}}{ }^{\prime}$ prays to the manitou for a healthy life.

This, indeed, is the time, namely, at sunrise, when those celebrating the gens festival have indeed begun singing. Nearly at sunset verily is when they have completed the gens festival. They do not hold gens festivals for a short period, as this is against their religion. (It should last until) the sun shall set.

Those celebrating the gens festival are not to go out at all. If they have seated themselves comfortably, there is where they are to sit all day. Nor is any one supposed to go out, prematurely. If, nevertheless, he does go out prematurely, then indeed, so it is said, he shall go at once to where he dwells. They have tobacco there to take out with them. Then they will burn it as an offering to that owl. It is said that only the old, those who have indeed become white headed, may continue to enter back (again). Now as for the young people. If they go out, they go home. It is said that it is against their religion for them to enter back again, that is, the young people who are celebrating the gens festival.

As for those invited, when the ceremonial attendants had merely started to talk at length, they ceased going out.

Nor, it is said, did they then keep on talking to each other. As soon as " $\mathrm{o}^{\prime} \mathrm{no}^{\prime} \mathrm{d}^{\mathrm{c}} \mathrm{c}^{\mathrm{C}}$ " was pronounced, then, indeed, every one ceased talking. Straightway, even those who were smoking would all remove their pipes from their mouths. ${ }^{1}$ No one smoked there during a speech. All sat very quietly. Only it is said that sometimes babies cried there during a speech. Then it was customary for the parent to go out. Then indeed she would go to where they lived. When she had arrived she would take off her finery where she (first) took it. This, it is said, is the way they did.

Twice during an entire summer they worshiped this sacred pack. And when they celebrated a gens festival in winter, they merely sang, no one danced; nor did they use dancing songs; nor did they smoke; nor did they untie this sacred pack: they merely had it (there). Moreover, they did not blow the flute. It was merely that exactly as they began to sing they merely rattled the gourds; at the time they did not beat the drum. Moreover, it was only the one giving the gens festival that made a speech. And after they had eaten any one that desired began to make a speech. This is what they did.

The women merely hum (the songs). Any one that feels inclined, hums. Not only the women celebrating the gens festival, but also 
kīgä'nutcigi wĩ'ku'medtcig i'kwäwag īni'gi nä'ku'gātcigkis. Inni-

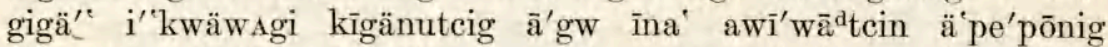

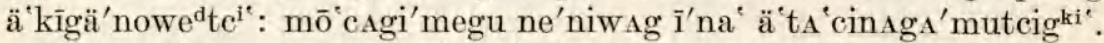

Me tenō'megu kwìye 'sä Ag îna ä'pitcigi pīti'gke'.

5 Ō'ni wâpi'gunani mene ${ }^{\prime} t$ ä pwāwi'mīdtcigi; cä'cki'megu kī'gänug īni'megu me 'tenō'i mī'dtcigi menā' ckunōn ä kî́'gänugki'.

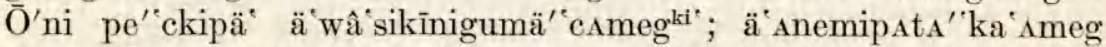

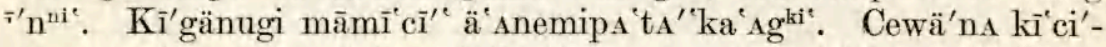

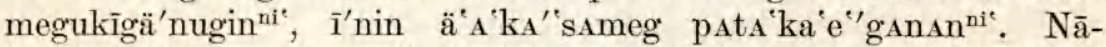

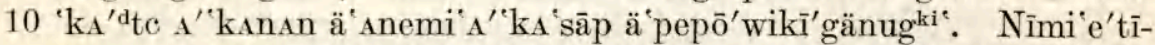

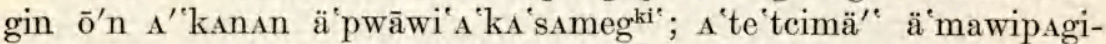
tamegi me'tegu'mi cīgi tcīgā' 'kwe wä dcike'siyāg utä'kwe wä${ }^{d}$ tcipwāwikī'ce" sowigki', I'n ä ca'wiwāa ${ }^{\mathrm{d}} t \mathrm{c}^{\mathrm{i}}$.

Ō'ni ma'nı pe'pigwä ckw ä'nstups'niwādtci nī'gānita māmaiys'15 megu ä'Anemi Anwäwä 'tagimä' megu; ke'dtcinīgwe kín'ce'sōn i’n ä-

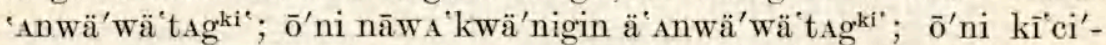

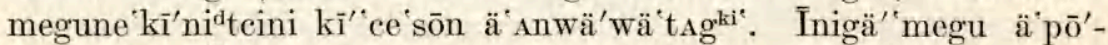
nīwādtci ${ }^{i}$. Ō'ni mīgā'tīwāte mani ${ }^{d} t c \bar{a}^{\prime \prime}$ anwä'wä'tagi pe'pi-

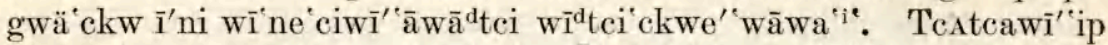
$20 \bar{a}^{\prime}$ gwi kA ckanwäwägate'nigin ${ }^{\text {ni'}}$. I'nip ä cige'nigini ke tename'gup

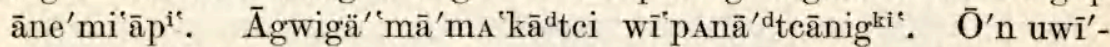
yä'Ani ta ci' $\bar{a}^{\prime}{ }^{\prime} k w a ̈ n i t e ~ k u^{\prime}$ 'semete manidtca ${ }^{\prime \prime}$ kīwāwī'ta pyā'te pe'pigwä ckw īnāmi ta' ipi anwä'wä'tag ō'n ína kägō'megu i'-

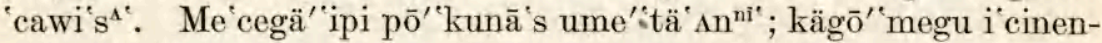
25 yä'pe'si ${ }^{\Lambda^{*}}$.

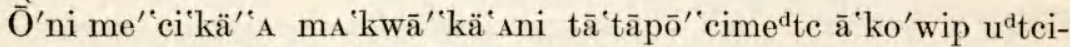
'ci'menä A wī'tegō ${ }^{\mathrm{wA}}$ '.

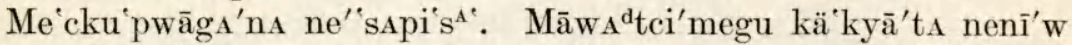

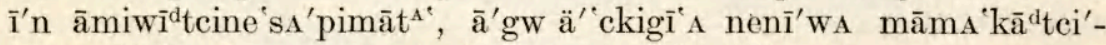
30 megu kä kyā'ta nenī'w āmiwīidcine 'ss'pimāt ${ }^{\wedge}$. Cewä'na nenīwa ne'ki'megu änäte'nigwäni nätu'pa'a ${ }^{\prime *}, \bar{i}^{\prime} n i n e{ }^{\prime} k i$ āmipwāwinegu'-

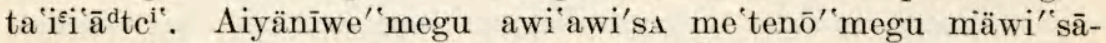

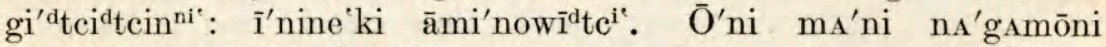
nāwA kwä'nigin āmi aiyōo $\bar{d}^{\mathrm{i}} \mathrm{i}^{\mathrm{i}^{\prime}}$ :

$$
\begin{aligned}
& \text { Wĩnā wìtnā' wìtegōwīpanīt; } \\
& \text { Me'tosä'neni'ā+ } \\
& \text { Wìtegōwīpanīt; winn wì'nā. }
\end{aligned}
$$

Ne'ki'megu änä'tenidtci nätu'pa`a`i wīna mani'megu pA'citō äyo" aiyō'de īni'megu ä cineguti'nAgAmōnni". "Ne'sA'piwina'gA-

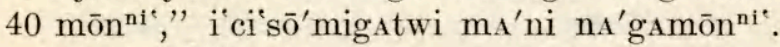

\footnotetext{
${ }^{1}$ In songs the plus sign (+) means that the vowel is protracted beyond normal length: ê indicates a very open long e. This sound does not occur in ordinary spoken Fox.
} 
those women who are invited, are the ones who hum. Now as for those women who celebrate the gens festival, they are not present when a gens festival is given in winter: men are the only ones who sing there.

Boys indeed are the only ones who are seated within.

Pumpkins are not the first things to be eaten inside; it is merely a kind of meat eaten only at a gens festival. And a hickory stick is sharpened at the point; and from time to time it (is used to do) the forking. At a gens festival a ceremonial attendant from time to time does the forking. But after the gens festival is indeed finished, these forks are burned. Moreover, the bones are constantly burned at a winter gens festival. At dancing occasions, then the bones are not burned; they are taken a far distance and thrown away at the foot of an oak tree on the north side where no sunlight will strike. This is what they do.

Now when they go on the warpath, the leader constantly blows this flute early in the morning; before sunrise is when he blows it; and at noon he blows it; and after sunset. Then they camp. If they are at war with each other, and if he really blows this flute, then they will overpower their foes. Sometimes, it is said, this flute will not sound. Then, it is said, if this is the case, it is very certain, it is said, that they are overpowered. (The flute) is in nowise ruined (though they think it is). And then if any one is angered and is to be feared, should (the leader) come actually with his flute, if he blows it there, then indeed something will befall (the man). Very likely, they say, he might break his bow, (or) he would get nervous in some way like this.

And then the snapping turtle and tortoise are placed side by side (lengthwise), and this owl should be laid directly in the rear (of them).

The catlinite pipe should remain at home. An extremely old man is the one who should contrive to be there with it, not a young man, but an old man is the one who should contrive to be with it. But as long as those on the warpath are away, so long shall the man contrive not to go anywhere. He should remain steadily on the spot unless indeed he goes out for toilet purposes: for so long is he permitted to go out. And then he should manage to use this song every noon:

It is he, it is he, who has the spirit of an owl;

A person

Who has the spirit of an owl; it is he, it is he. ${ }^{1}$

As long indeed as those on the warpath are away, this old man keeps on using this one song. This song is called "Stay-alone song."

\footnotetext{
1 The man sings how he was blessed, referring to the owl. The man is talking about himself. He has the spirit of an owl by his blessing.
} 


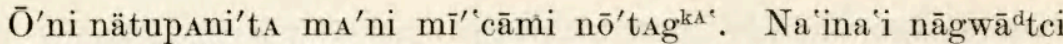

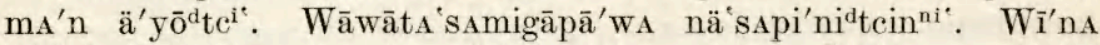

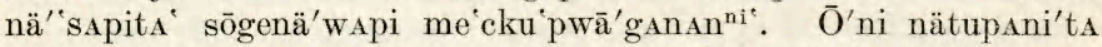

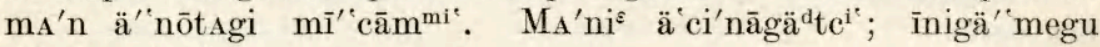
$5 \ddot{a}^{\prime \prime}$ nāgwa $\bar{a}^{d} t c^{i^{\prime}}$ :

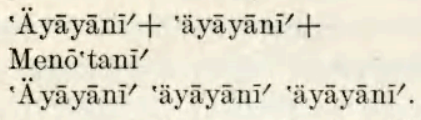

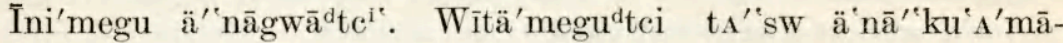
$10 \mathrm{gu}^{\mathrm{d}} \mathrm{tc}^{\mathrm{i}^{*}}$.

Mānemegupā'pe'e mai'yōwagi me to sänèniwag innigä'megu

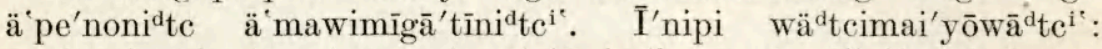

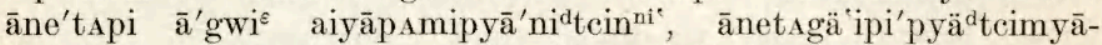

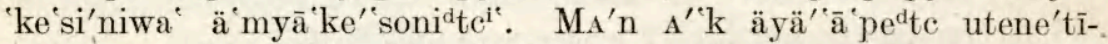

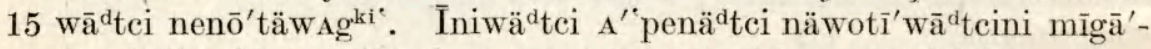

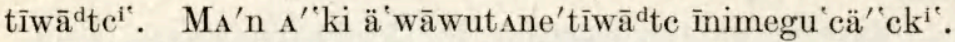

$\bar{O}^{\prime}$ ni mä ${ }^{\prime}{ }^{\prime}$ ni kīgä'nowin ${ }^{\prime} g_{A}^{\prime} \operatorname{mōnan}^{\text {ni' }}$

Tepe'kwīi nōtamānī',

Tepe'kwi' nōtamānī',

Na'ägaiyō nōtamānī't.

WA'kwiye,

Wìta'mōnānīt, wīta'mōnānīt,

Wā+sōnī, wā+sōnī.

$\mathrm{Na}{ }^{\prime} \operatorname{egā}^{\prime}+\mathrm{kutowä}+$ nō+,

$\mathrm{Ku}^{\prime}{ }^{\prime} k u^{\prime} k u^{\prime} \bar{u}^{\prime} w a \bar{a}, k u^{\prime} k u^{\prime} k u^{\prime} \bar{u}^{\prime} w a \bar{a}$,

$\mathrm{Na}^{\prime} \operatorname{ega}^{\prime}+$ kutowä+nō.

Na'egā'+ kutowä+nō.

Wäpi'sātā+, wäpi'sātā+,

Winā manetowā't,

Wäpi'sätā+, wäpi'sātā,

Wäpi'sātā, wäpi'sātā.

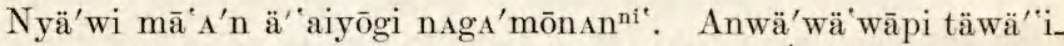

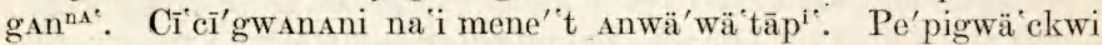

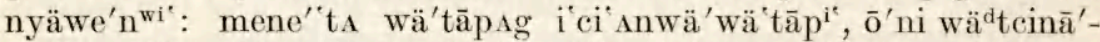

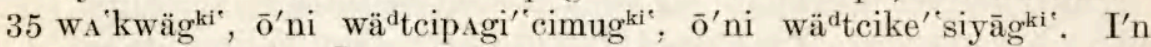

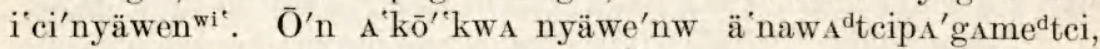

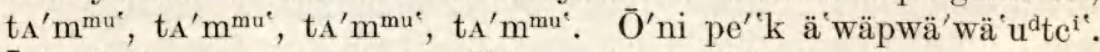

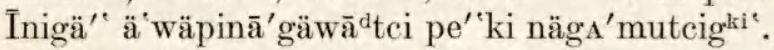

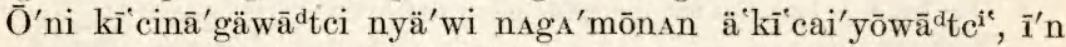

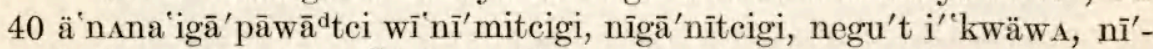
'cwi ne'niwagki'. O O'ni mani'megu nīgā'negāta nenī'wa änwä'wä-

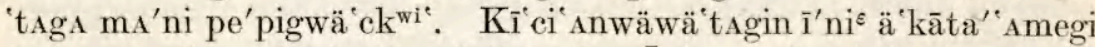

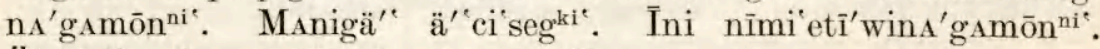
Ä nīmi wa's Ameg ä'yōgi na'gamōnni"

1 The sacred pack is "what I carry on my back." "Late at night" is the real meaning of "at night." "The inner significance of the song is that all on the warpath come back alive, with none killed. The word wä +söni is not used today; it is a shortened word used in fighting. The word wA'kwi'ye (for WA 'kwi' in songs) is likewise obsolete. 
And the one on the warpath is the one who carries this sacred pack on his back. When he departs he uses this (song). He stands beckoning the one who stays alone. The one who stays alone has the catlinite pipe in his hand. And the one on the warpath is the one that will have this sacred pack on his back. This is the way he will sing; and then he departs:

Where I am going, where I am going,

?

Where I am going, where I am going, where I am going.

Then indeed he departs. He is accompanied by as many as he is assisted in singing.

Many people frequently cry when the others start off to war. This, it is said, is the reason why they cry: some do not come back, some come crippled when they are wounded. This land is what the Indians are always fighting over. This is why they always fight against each other when they see each other. For possession of this land is the only cause.

Now these are the gens festival. songs:

What I carry on my back at night,

What I carry on my back at night,

What I carry carefully on my back. ${ }^{1}$

In the sky,

I tell you, I tell you,

They are bright, they are bright. ${ }^{2}$

Try to hoot slowly,

$\mathrm{Ku}^{\prime \prime} k{ }^{\prime} k u^{\prime} \bar{u}^{\prime} w \bar{a}, k{ }^{\prime} k u{ }^{\prime} k u^{\prime} \bar{u}^{\prime} w a \bar{a}$,

Try to hoot slowly,

Try to hoot slowly. ${ }^{3}$

The one who started to fly away, the one who started to fly away,

It is he, the manitou,

The one who started to fly away, the one who started to fly away,

The one who started to fly away, the one who started to fly away. ${ }^{4}$

They use these four songs. The drum is beaten. Yet the gourds are first rattled. The flute is blown four times: first it is blown toward the east, then toward the south, then toward the west, then toward the north. So it is four times. Then they stop to beat the drum first four times, tum, tum, tum, tum. Then is when it is begun to be beaten vigorously. Then, too, the singers begin singing loudly.

After they sing, after they use the four songs, then those who are going. to dance make firm their foothold (i. e., arrange themselves in a line), that is, the leaders, one woman and two men. Then the leader, a man, blows this flute. After he has blown it, then a song is started. This is how it is. It is a dancing song. The song is used when there is dancing.

3 The hidden meaning is: "sing slowly," but the song also refers to the owl.

1The esoteric meaning of the song is: "After the owl blessed the man, then the former flew away." 
Ketuketunō'+, ketuketunō' + , ketuketunō,

Witegowä+,

Ketuketunō', ketuketunō'.

5

Wäwäpe'ce'sā+,

Wäwäpe'ce'sā+,

Wäwäpe'ce'sā+;

Yõ+, nenegwi'kanegī't;

Wäwäpe'ce'sāt,

Wäwäpe'ce'sāt.

Äne'kwänemānī wìtegō'uwī'ci nīnA,

Äne'kwänemānī wītegō̄uwī'ci nīnA,

Äne'kwänemānī wìtegō‘uwī'ci niñA.

'Ānemīyäwi, 'ānemīmyäwīwīwī,

Wìnā yō't me cì'genā'kwe;

'Ānemīmyäwīwī nīnā+, 'Anemīmyäwì,

'Ānemimyäwiwī nīnāt.

Nīnā+ kê+kudtci'ene, nīnā+ kê+kud tci'ene;

Winā + winaiyō' mi' kwA'kê;

Winaiyō' me 'ci'kêt;

Nīnā $+\operatorname{kegu}^{d}$ tci'ê+ne, nīnā+ kegu ${ }^{d}$ tci'ê+ne.

Kī'ce'sōgīt nīnaiyō+,

Kī'ce'sōgīt nīnaiyō+,

Ninā+;

Nemā+nemātapīnō+,

Nemā+nemātapīnō+;

Kĩ'ce'sōgī + nīnaiyō+,

Kī'ce'sōgīt nīnaiyō+.

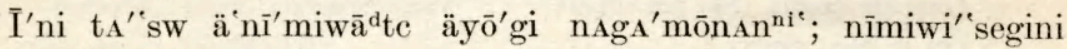
kutwā' $\mathrm{ci}^{\prime} \mathrm{g}^{\mathrm{kA}}$.

$\bar{O}^{\prime}$ ni wïseniwinaga'mōnan ${ }^{\text {ni }}{ }^{\circ}$ :

Kīwī'senītā+,

Kīwī'senītā+:

Yowīnnā+ manetowā+;

Kìwī'senīāa,

Kīwī'senītā.

$\overline{\mathrm{A}}+{ }^{\prime}$ kwikumātā + winā + :

$\overline{\mathrm{A}}+$ 'kwikumātā+'wīnā+:

Yo manetowā wī'senitwa'ī't

$\overline{\mathrm{A}}+$ 'kumātā+; $^{\prime}$

$\overline{\mathrm{A}}+$ 'kwikumātā+.

Wäwäpī+ne'ke'tōnānī+,

Wäwäpine'ke'tōnānī+;

WīnA yō+ mānī wì'seni nī +na

Yō mānī wī'seni nī+nA;

'Wäwäpī+ne'ke'tónānī,

Wäwäpinne'ke'tänānī+wīnA.

1 The owl is asked to hoot to show that Black-Rainbow has been blessed by him.

${ }^{2}$ The esoteric meaning of the song is that if the one blessed is hard pressed by his enemies and uses this song, the owl will flap his ears, cause wind, and save him.

3 The inner signification of the song is: The man is on the warpath; in whatever direction he turns the owl's head, he will triumph over his foes in that direction.

4 They sing this after a war party to show all come back without being killed.

${ }^{5}$ Supposed to be said by Black-Rainbow. He means that he is going to test what results he will get from his blessing. 
Hoot, hoot, hoot,

Owl,

Hoot, hoot. ${ }^{1}$

He would flap his ears,

He would flap his ears,

He would flap his ears;

Yo, in my wing;

He would flap his ears,

He would flap his ears. ${ }^{2}$

The way I turn the owl's head,

The way I turn the owl's head,

The way I turn the owl's head. ${ }^{3}$

A continuous way, a continuous way,

$\mathrm{Y} \bar{o}$, it is he, the snapping turtle;

I am a continuous way, a continuous way,

I am a continuous way. ${ }^{4}$

I shall test you, I shall test you;

It is he, it is he, tortoise;

It is he, snapping turtle;

I shall test you, I shall test you. ${ }^{5}$

Here I am in the sun,

Here I am in the sun;

$\Lambda \mathrm{m}$ I,

Sit very upright,

Sit very upright;

Here I am in the sun,

Here I am in the sun. ${ }^{6}$

That is the number of songs used when they dance; there are six dancing (songs).

And the eating songs (are):

He that goes about eating,

He that goes about eating;

Ife is a manitou;

He that goes about eating,

He that goes about eating. ${ }^{7}$

The one who has a sharp beak, it is he;

The one who has a sharp beak, it is he;

The manitou who eats;

The one who has a sharp beak;

The one who has a sharp beak. ${ }^{8}$

I am waving my hand at you,

I am waving my hand at you;

I who am eating this,

I who am eating this;

I am waving my hand at you,

I am waving my hand at you. ${ }^{9}$

${ }^{6}$ This refers to the warriors who have been successful in killing their enemies. s i They are told to sit upright to be prominent persons. Sometimes the warriors are outside $($ " $f$ in the sun"), bocause it is smoky within. But they have to come inside.

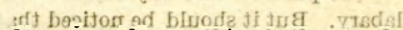

${ }^{7}$ This refers to the owl. This is after the ceremonial attendants have sefmed everything to the people. The owl gets the benefit of the feast.

${ }^{8}$ This is after the food has been served. The owl is told to go ahead and eat.

"The phrase rendered by "I am waving my hand at you "is álso capable of theaning if am losing hearing of you." The former is the sense intended. One of the ceremonial attendants is aiso to "eat after he has served the people, He gets up and waves his hand four times, praying to the owl. The people eat after he has done this. 


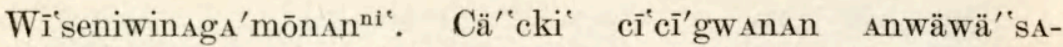

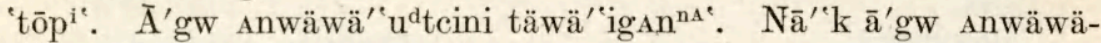

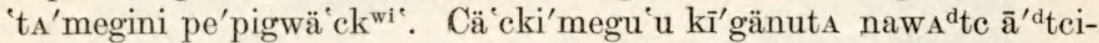
mōwa, ämamā'tomā ${ }^{d}$ tci wìte'gowan aiyowä' megu äpi'ni ${ }^{\mathrm{d}}$ tcini mī'5 'cāmegi ke'tcima'netowani mani ${ }^{\varepsilon} \mathrm{A}^{\prime} \mathrm{ki}$ kīci'tō'nidtcini tcāgi-

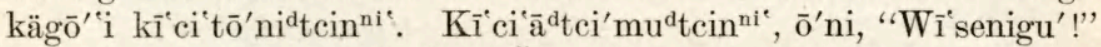

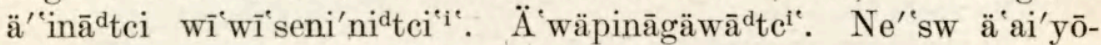

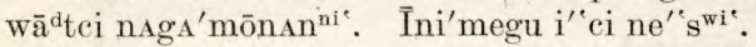

$\bar{O}^{\prime}$ ni nāta'winōninagA'mōnan ${ }^{\text {ni" }}$ :

Kakānwì+ pe`ckunä'wī'i nīyawìt,

KAkanwì pe'ckunä'wīi nìyawi;

' $U^{d}$ tce ${ }^{d} \mathrm{u}^{\mathrm{d}}$ cepe ${ }^{\prime}$ kīwīwi niyawī+;

Kakānwīt pe'ckunä'wī'i niyawīt.

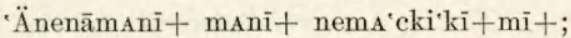

$\overline{\mathrm{I} n \overline{+}}+$ 'i'cigenwìt;

'Änenāmanì + manī + nemA'cki'ckī+mì +;

Înīt 'i'cigenwìt;

'̈̈nenāmanī +ni ${ }^{\varepsilon}$ mani nemA ${ }^{*}{ }^{\prime}{ }^{\prime} k \bar{i}+\mathrm{m} \bar{i}+$;

$\overline{\mathrm{In}}+$ cigenwìt.

'WA $\mathrm{A}^{\varepsilon}$ !nī +nā+ yō+, 'WA $\mathrm{A}^{\varepsilon} ! \mathrm{n} \overline{1}+\mathrm{na} \overline{\mathrm{a}} \mathrm{o}+{ }^{\prime} \bar{o}^{\prime}+$;

Sā'sāgō+ tcepi'tkānī+;

Sā'sāgō+ tcepi'kānī+;

'WA ${ }^{\varepsilon} ! \operatorname{nin} n a \overline{+}$ yō, $\mathrm{WA}^{\varepsilon} ! \operatorname{nin} \bar{a}+$ yõ $+{ }^{\prime} \mathrm{o}+$.

Kîwikīwī+'cinānê+,

Kīwikīwī+'cinānê+,

Pe'ckunä'+wīkī+ yō mani nī+yawi,

Kîwikīwī+'cīnānê+,

Kīwikīwì+' cinnānêt.

'Anemō'moyā+nī,

'Anemō'moyā+nī;

Kīwitê' + gowāgī 'we'taiyō' + we'niyane 'utaiyowe'nwāwi $\varepsilon$;

'Anemō'moyā+nī,

'Anemō'moyā+nī.

Nātawinō'nin AgA'mōnan î́n ä cinyā'nAnegki'.

$35 \bar{O}^{\prime}$ ni me cku'pwā'ganina'gamōn ${ }^{\text {ni' }}$ :

'Īnaiyõ 'änê+'kA,

'Īnaiyō 'änế $+{ }^{\prime} k_{A}$ wì $+n a^{\prime} \varepsilon$,

'Īnaiyō 'änê' $+{ }^{\prime} k_{A} w^{1}+n^{\prime} \varepsilon$;

$\mathrm{Y} \bar{o}^{\prime}+\mathrm{mA}^{\prime}$ netowa $\bar{a}^{\prime}$ yō' $+\mathrm{mA}^{\prime}$ netowa $\bar{a}^{\prime} ;$

$40 \mathrm{~W} \overline{1}+\mathrm{na}^{\varepsilon}$;

'Īnaiyō 'änê' $+{ }^{\prime} k A$,

'Īnaiyō 'änê' $+{ }^{\prime} \mathrm{e}^{\prime} \mathrm{kA} \mathrm{wi}^{\prime}+\mathrm{na}^{\prime} \varepsilon$.

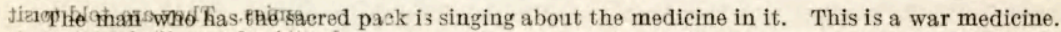

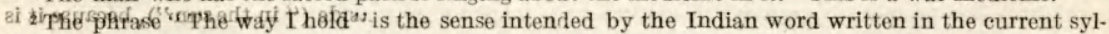
labary. But it should be noticed that, the current syllabary being at times ambiguous, the word could mean "Y Y leg may be cured by using this weed.

3. W e $^{\varepsilon}$ is an exclamation 14 sed when any, one is shot or dead. This is what a man says for taking his friendson the warpath ${ }_{B}$ it is his fanlt if they are shot or killed. He prays to the roots to cure them.

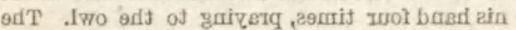


(These are) the eating songs. Only the gourds are rattled. The drum is not beaten. Nor is the flute blown. The one who gives the gens festival speaks first, praying to the owl who is in this sacred pack and the Great Manitou who made this earth, who made everything. After speaking then he says to those who are to eat, "Eat!" Then they began singing. They use three songs. It is just three.

\section{Now the medicine songs:}

I am the long flower myself,

I am the long flower myself;

My body has many roots;

I am the long flower myself. ${ }^{1}$

The way I hold this weed of mine;

That is how it is;

The way I hold this weed of mine;

That is how it is;

The way I hold this weed of mine;

That is how it is. ${ }^{2}$

' $W_{\mathrm{A}} \varepsilon ! \mathrm{I}$, yō+, wA $\varepsilon$ ! I, yō+'ō'+;

The roots are sticking out;

The roots are sticking out;

'WA ${ }^{\varepsilon}$ ! I, yō, $\mathrm{wA}^{\varepsilon}$ ! yō+'ō+. ${ }^{3}$

If you are lying sick,

If you are lying sick,

I am this flower,

If you are lying sick,

If you are lying sick. ${ }^{4}$

I am going along weeping,

I am going along weeping;

I have the spirit of owls, their spirit;

I am going along weeping,

I am going along weeping. ${ }^{5}$

The medincine songs are thus five.

Now the catlinite pipe song $(\mathrm{s})$ :

Here is the one who speaks of you,

Here is the one who speaks of you,

Here is the one who speaks of you;

It is the manitou, it is the manitou;

It is he;

Here is the one who speaks of you,

Here is the one who speaks of you. ${ }^{6}$

4 The man who owns the sacred pack is speaking to the wounded, and is going to cure them with the medicine.

5 Many have been killed and wounded. The man goes about weeping, telling that he was blessed by the owl, and is to cure them by the medicine.

${ }^{6}$ The inner meaning of the song is: The manitou is going to smoke, and all the people will smoke. All should smoke who can. 
Wì+'ima'netowigīt,

Wì +'ima'netowigìt;

$\mathrm{Ni}+\mathrm{yo}+\mathrm{nAna}+\mathrm{a} w i w i n e y \bar{a}+$,

Yō+ nanākwiwineyā,

$\mathrm{Wi}^{\prime}{ }^{\prime} \bar{i}+\mathrm{ma}^{\prime}$ netowigi $\bar{i}^{\prime}+$,

$\mathrm{W}^{\prime}{ }^{\prime} \cdot \overline{1}+$ ma'netowigì,

Wì'‘ì+ ma'netowigì.

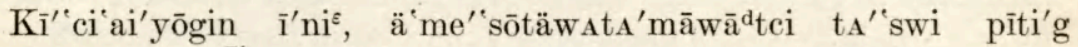

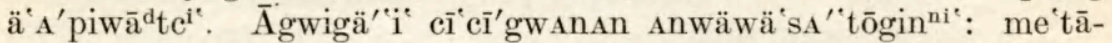
10 'kwi'megu nagA'mowagki'. $\bar{A}^{\prime}$ gwi wī'nA kīgä'nutcig Atamā'wā_

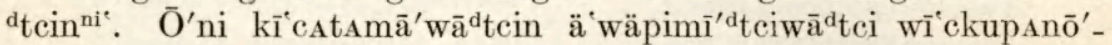

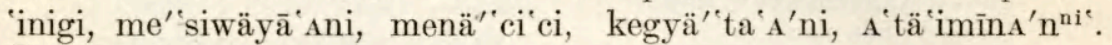
$\bar{O}^{\prime}$ n ä'nagamowādtci'megu nā' kA'dtci kīgä'nutcigki':

Wì + manetō+wiwi nīyā+wi,

15 Wì + manetō+wīwi nīyā +wi,

Wì + manetō+wīwi nìyā+wi,

Wì + manetō+wīwi nìyā+wi.

Wì+ māwiwäpê+tonōgī,

Yō+ maneto'āgī;

20 Wì +māwiwäpê+tonōgî,

Yō+ maneto'āgī;

Nanāgwì + wA'kwīyē+ tānetunogī,

Yō maneto'āgī;

Wì+ māwiwäpê+tonōgī,

25 Yô maneto'āgī.

Cā'cā'kwänō+, cā'cā'kwänō+, cā'cā'kwänō+, cā'ca'kwänō+ō+,

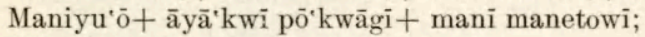

Cā'cā'kwänō+, cā'cā'kwänō+nō+'ō.

30. Kîwīt'senipanīt

Manetō+gi ä'nō'sä+,

Manetōgīt 'änō'sä+,

Kiwi'senipsnigì + netawä+pemagì.

Ä'Anwä'wä'udtei täwä' igana mā's'n ä'aiyōgi nyä'wi nagA'mō-

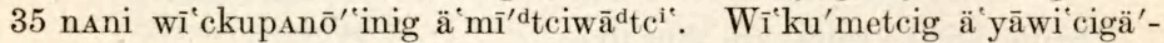

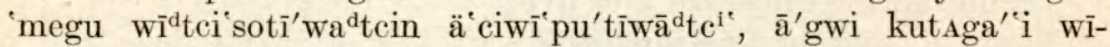

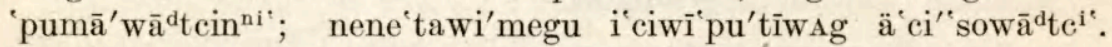
Mene'ta'megu pä'ki'metcigi mä'kwi"sutcigki", $\bar{o}^{\prime}$ 'ni me cemegō'na innigi'megu; cä'cki pä'kimetcigi mene' ${ }^{\prime 2}$ A mä'kwi'sutcigki`. Me40 'cewīn ${ }^{d} t c \bar{a}^{\prime}$ megu i'kwäwagi'gä' Apeno Agi'gä i wī'se'niwagi pwā'wikīgä'nutcigki'.

$\bar{O}^{\prime}$ ni mäyōwi' 'segini nagA'mōnan ${ }^{\text {ni': }}$

'Ice'go'ī+ kemaiyo'ā'penā+,

Me'to'sänenī'ā kemaiyō $+\bar{a} '$ penā;

45 Wīnā yō+, winā yō+;

Me'to'sänenī'ā kemaiyō'ā'penā wīnā;

I'cego'ī' kemaiyo'āpenā.

1 This song is used after the people have smoked; and then the owl is given a chance to smoke. Then the pipe is put away.

2 Black-Rainbow shows that he has been blessed.

${ }^{3}$ This song refers to all the fowls that have sharp beaks and claws. Many men have been left dead on the battle field, and are eaten by these fowls. They are reporting this to the owl, because he is the cause of it, and they are praying to the owl to help the dead. 
It has the nature of a manitou,

It has the nature of a manitou;

In between the ears,

In between the ears;

It has the nature of a manitou,

It has the nature of a manitou,

It has the nature of a manitou. ${ }^{1}$

After (these songs) are used, then everyone, as many as are seated inside, smoke. The gourds are not rattled; they merely sing. Those celebrating the gens festival do not smoke. And after they have smoked, they begin eating sweet (foods), maple-sugar cakes, maple syrup, hazelnuts, strawberries. And then those giving the feast sing.

My body has the nature of a manitou,

My body has the nature of a manitou,

My body has the nature of a manitou,

My body has the nature of a manitou. ${ }^{2}$

They begin to move their mouths,

Yō, the manitous;

They begin to move their mouths,

Yō, the manitous;

In the middle of the sky, they move their mouths up and down,

Yō, the manitous;

They begin to move their mouths,

Yo, the manitous. ${ }^{3}$

You soul, you soul, you soul, you soul,

$\Lambda$ re half the nature of a manitou;

You soul, you soul. ${ }^{4}$

We shall eat, my people,

Where I go,

As I go as a manitou,

As I go as a manitou;

We shall eat, my people. ${ }^{5}$

The drum is beaten when these four songs are used and when they eat the sweet (foods). Those invited eat according to their gentes; different gentes are not to eat together; the gentes of each kind eat together. And people belonging to the Bear gens are invited first, then (those) of any other (gens); only those belonging to the Bear gens are invited first. Any women and children eat who do not belong to the gens giving the feast.

Now the wailing songs:

Just for fun we make them cry,

We make the people cry;

To be sure it is;

The people we make cry;

Just for fun we make them cry. ${ }^{6}$

${ }^{1}$ The song shows that the soul is a spirit, and could be seen in person if it willed it.

5 The inner meaning of the song is that when the people go to war, they can always find game and things to eat, because Black-Rainbow was blessed.

6 The metrical structure of this song is not altogether clear. All the songs called "wailing-songs" are used by children when they fast. The meaning of this song is that a large number of the enemy has been killed. 
Wīnā, wīnāt,

Wìtegō+wī'panī me'to'sänenī'A;

Wīnā, winnā+,

Wìtegōwīpanī me'to'sänenī'ā;

5 Winā, wīnā.

Teāgi maiyowagī' manetowagī' +

Kìwetamānī, kīwetamānī;

Tcā +gī maiyowAgi' manetowAgi' + .

10 Wâ'kwì maiyom

$\overline{\mathrm{A}}+$ 'kwā+'kāmīgākīní;

Maiyowī $\overline{1}+n i$ wā' kwiye 'íiyê+na $a^{\varepsilon}$.

$\overline{\mathrm{I}}^{\prime} \mathrm{n}$ äcinyäwegi mäyōwi'segini nAgA'mōnann ${ }^{\mathrm{ni}}$. $\overline{\mathrm{O}}^{\prime} \mathrm{n} \quad \bar{a}^{\prime} \mathrm{gw}$

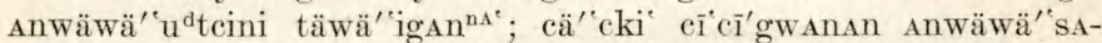

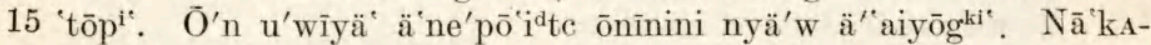
nitepe kwe nyäwe'nwi nAgA'mowagki'. Mā'Anigä' megu nyä'w

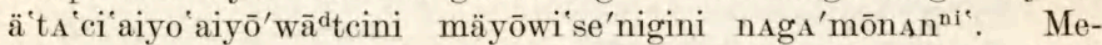

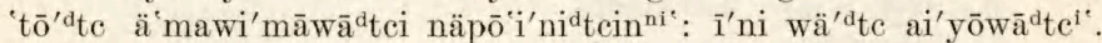
Cä'cki cīcī'gwanan anwäwä'sA'tōwagki’. Āgwigä’ u'wīyä`A

20 nō'ta wīnepādtc ${ }^{i *}$. Nā'kanitepe 'kwe nā' ka āgu'wīyä's' cegi' -

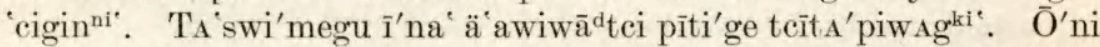

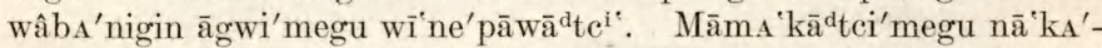

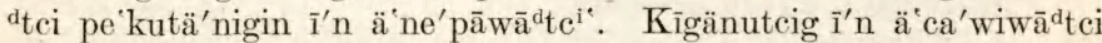

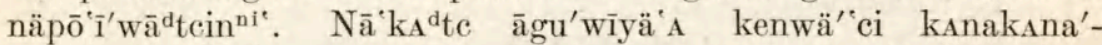

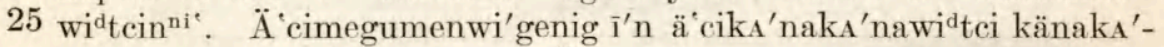
nawita nōmagä'wä'megu. $\bar{O}^{\prime} n$ i'kwäwag $\bar{a}^{\prime}$ gwi nākuwä'wā-

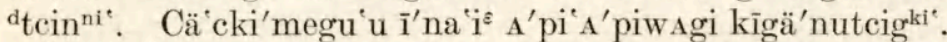

$\bar{O}^{\prime} n$ ä'wī'se'ninidtci mä'Ani'megu mäyōwi'se'nigin äyōwā ${ }^{d} \operatorname{tcin}^{\mathrm{ni}}$. Ini'megu i'cinyäwi nagA'mōnan äyō'wā $\bar{a}^{\mathrm{d}} \operatorname{tcin}^{\mathrm{ni}}$.

$30 \bar{O}^{\prime}$ nīna näpōit ä`s'soyā'kwi'cimedtci kīgä'nutcigi wä'dtc uts'-

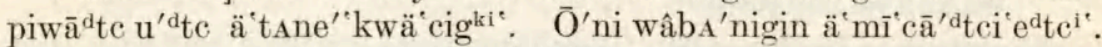

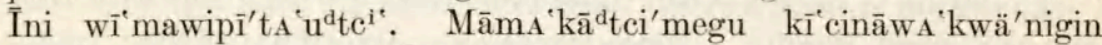

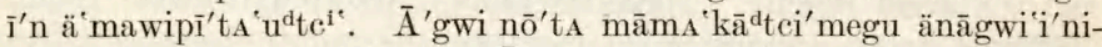

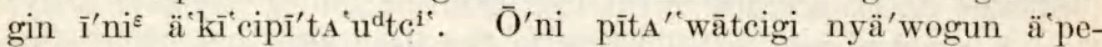

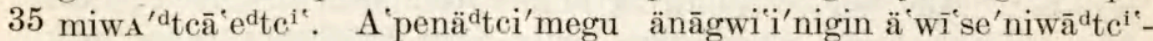
$\bar{O}^{\prime}$ ni nyäwogunagaténigin $\overline{1}^{\prime} n$ ä kanakA'nawidte ${ }^{i}$. Näānagetu. nämu't ä'kaks'nōtagi wī'mī'deiwādte ${ }^{i}$. I'ni.

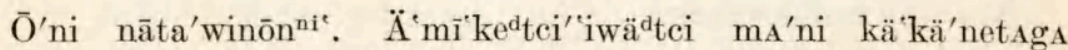

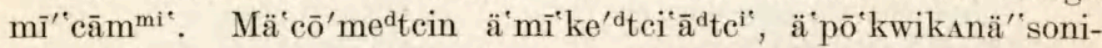
40 dtci, me cena'megu ä'tA ci'nigwäni mānänite'gäi, pe 'ki'megu pā'tā'sō'nidtci“i, pō'kwikanä'ssonite, -wīns'megu kegime's s ō'ni mī-

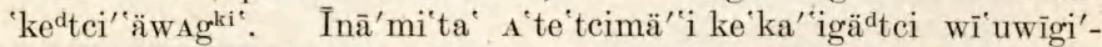

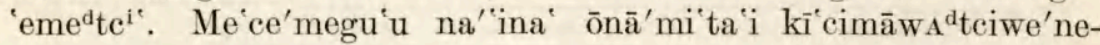

1 The song refers to the owl. The children pray to the owl to obtain a blessing.

2 The children use this song to obtain a blessing.

3 It was impossible to get the inner meaning of this song. 
It is he, it is he,

The person with the spirit of an owl;

It is he, it is he,

The person with the spirit of an owl:

It is he, it is he. ${ }^{1}$

All the manitous are weeping,

Because I go around weeping, because I go around weeping,

All the manitous are weeping. ${ }^{2}$

The sky will weep,

The sky,

At the end of the earth;

The sky will weep. ${ }^{3}$

The wailing songs are thus four. And the drum is not beaten; only the rattles are shaken. And when any one dies those four (songs) are used. They sing four times during the entire night. These four wailing songs are used there again and again. (It is) the same as wailing over one who has died: that is why they use (the songs). They only rattle the gourds. And no one is to go to sleep prematurely (i. e., before the ceremony is completed). Moreover, during the entire night no one lies down. As many as are there inside are seated. And they are not to sleep the next day. Surely the following night is when they sleep again. That is what those celebrating the gens festival do when (a member of their gens) dies. And no one speaks at great length. The speaker speaks for a little while on such things as are pleasant. Nor do the women hum. Those celebrating the gens festival merely sit there.

And when (the others) eat, they use these wailing (songs). They use precisely (these) four songs.

And the one who is dead is laid slantingly with his head toward where those celebrating the gens festival are seated. ${ }^{4}$ And the next day he is clad in finery. Then he is taken to be buried. It must be in the afternoon when he is taken to be buried. It must not be late in the evening when he has been buried. And those who bury him are given meals for four days. It is always in the evenings when they eat. On the fourth day (some one) then makes a speech. One that is accustomed to speaking speaks to what they are to eat. ${ }^{5}$ That is all.

Now as to the medicine. One who knows this sacred pack practices doctoring. He doctors one that is shot, who has a broken bone, or what not, even if he has many wounds, even those who are severely wounded, if they have broken bones-yet he doctors them all. He would select a place far away for a wickiup to be made for them. And at the time when any one had been taken there, he would go

1 Ordinarily poles are fastened on either side of the corpse, and the whole is leaned upright at the back of the wickiup toward where the singers are seated. The next day the body is clad in finery.

5 As if it had life in it. 


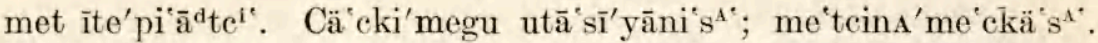

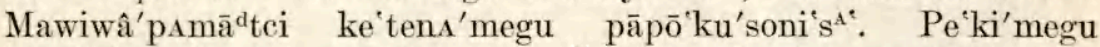

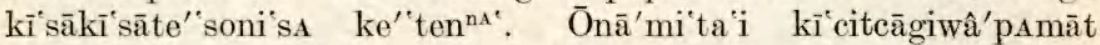

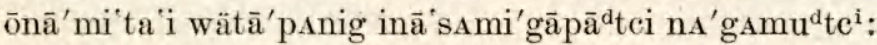

Kìwikīwì̄' cinānê+;

Kỉwikīî̀+' cinānê+,

Pe'ckunä'+wikì yồ+mani nì+yawi,

Kìwikīwī+'cinānêt,

Kiwikiwìit'cinānêt

10 I'nipi ā'mi aiyō'dtei mene $t^{\prime}{ }^{\prime}$ megu $\mathrm{nA}^{\prime} \mathrm{g}_{\mathrm{A}} \mathrm{mōn}^{\mathrm{ni}}{ }^{\mathrm{i}}$. Ne'nōtäwine'sämāwA'nipi kegine deä'gāpā'sa wätā'panig i'cime cki'nedtcä -

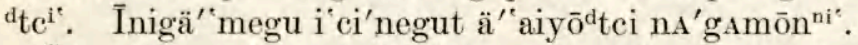

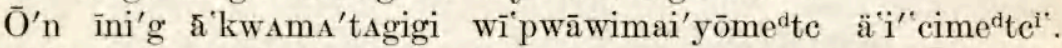

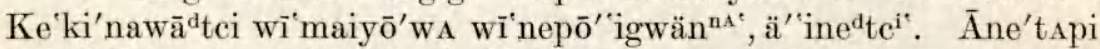

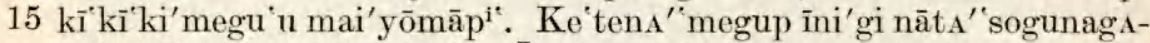

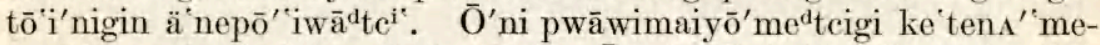

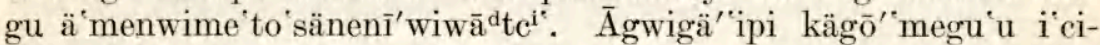

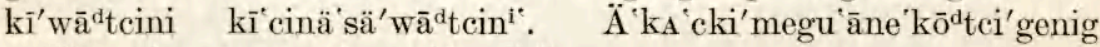
utō'kane'mwāwan ä 'tagwi'genigi ${ }^{\text {' }}$.

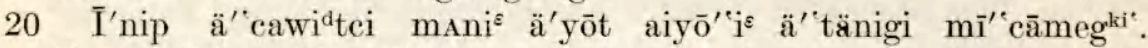

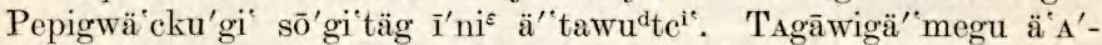
'tawu ${ }^{d} t^{i}{ }^{i}$. Cewä'na me'tenō'megu wâpe ckyägi'nidtci' A'sạa'a' ä-

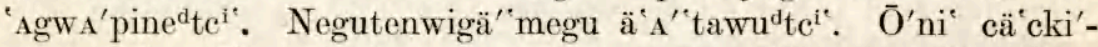

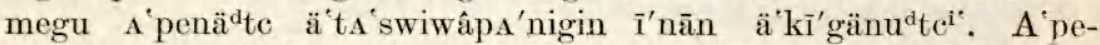

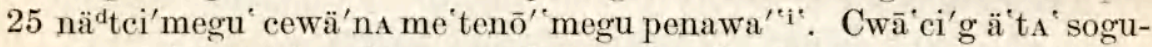
nagate'nigin ätcāgi'megunä'sä ād ${ }^{\mathrm{d}} \mathrm{c}^{\mathrm{i}}$. Cewä'n inni“i'megu kīgä'nu-

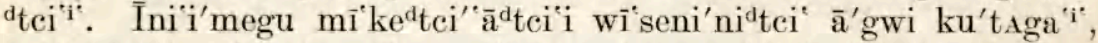
īni i'megku”. Cewä'n īni'megu i cinäne'gutenwi wī'se'niwādtci mī'ke-

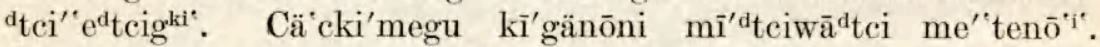

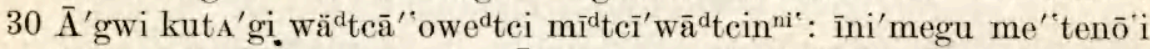

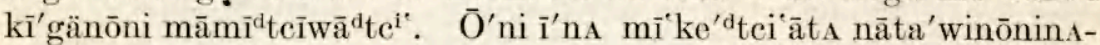

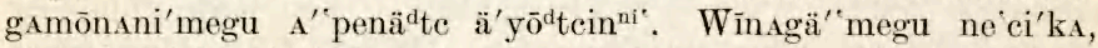

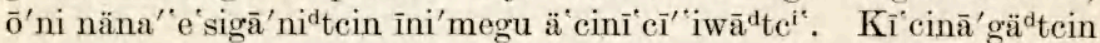

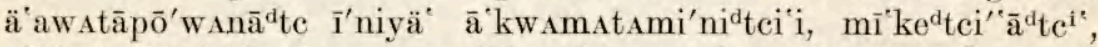

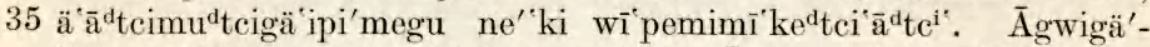

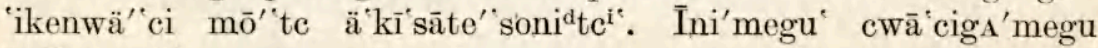
$\tan ^{\prime \prime} \operatorname{sogun}^{\mathrm{ni} \text {. }}$.

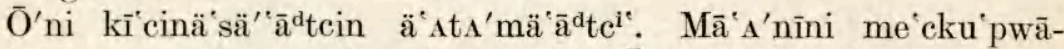

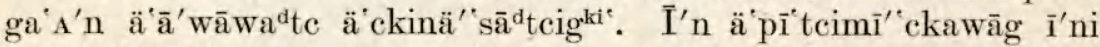

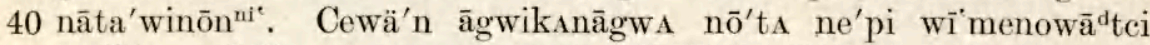

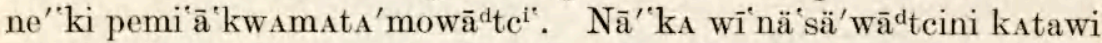

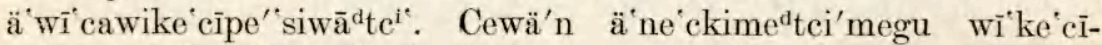

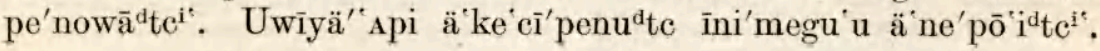


there. He would only wear his breechcloth; (otherwise) he would be naked. When he went over to see, sure enough there would be one whose bones were broken. Truly there would be some who were badly shot. And after he might have seen them all, he might stand facing the east and sing:

If you are lying sick, ${ }^{1}$

If you are lying sick,

I am a flower,

If you are lying sick,

If you are lying sick.

It is said that he would use that song first. It is said that he would stand holding Indian-tobacco in his hand, and holding out his hand opened toward the east. He used just that one song.

And those who were ill were told not to ery. When one cried it was a sign that he would die, he was told. Some, it is said, nevertheless were made to cry. It is said that it was a fact that several days (later) they died. And those who were not made to cry truly lived in health. It is said that nothing was the matter with them after they were cured. Their bones were able to lengthen out and grow together.

That, it is said, is what happened to one who used this (medicine) which is here in the sacred pack. (The medicine) tied on to the flute was used. Very little was used on him. But only white hides were used as bandages. (The patient) was given only one (treatment). And then he only gave always a gens festival every day. But turkeys always were the only (things offered). In eight days he healed all. Those were the ones who gave the gens festivals. Those whom he doctored were the ones who ate, no others. But those who were doctored ate also once apiece. They ate only at the gens festival. They did not eat at any other meal that was cooked: it was only at the gens festival that they all ate. The one that doctored them always used medicine-songs. It was indeed he alone, and the one who attended to the cooking: and so they were just two. After he sang he carried the food to the sick mentioned before, those whom he doctored, and related, it is said, how long he would continue to doctor them. Yet it was not long even when they were wounded. It was just the same (length of time): eight days.

And after he had cured them he gave them a smoke. Those just cured used this catlinite pipe. The medicine was powerful to that extent. But they were not allowed to drink water at all as long as they continued siek. Moreover, when they were nearly on the point of being cured they itched terribly. But they were forbidden to scratch themselves. It is said when any one scratched himself, he died at once. It is said he acted as if he were shot. And if he drank 


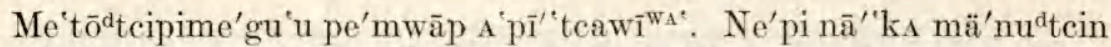

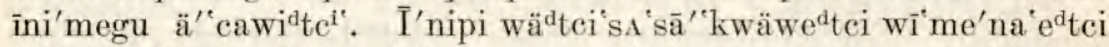

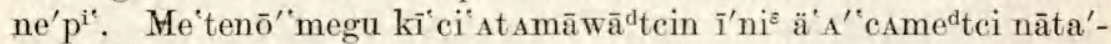

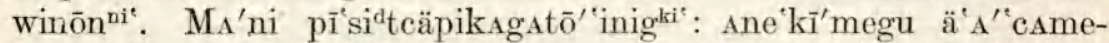

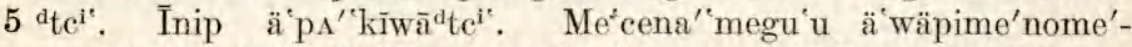

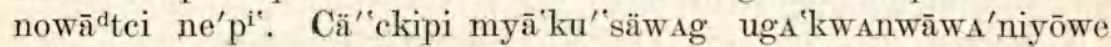

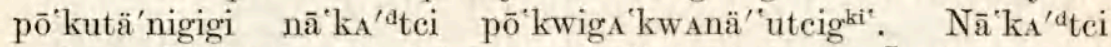

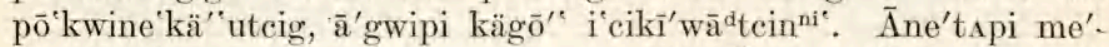
'tenō'i wâgige'niwan utō'kane'mwāwan ni'. Ānetagä' 'ipi pe'kwigh'-

10 näwAgki'; cä'ck āgwigä'pe'ki tıgāwi'megu'u äpe'kwigs'näwādtci ${ }^{i^{\prime}}$.

$\bar{O}^{\prime}$ n änstu'panig ä'cawig ä'mī'gātīgki'. MA'ni ma'ckimu'-

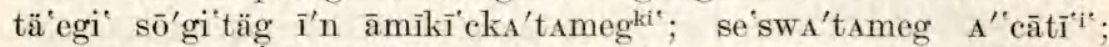

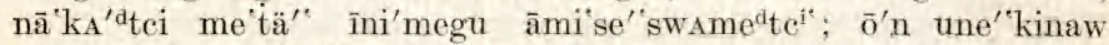

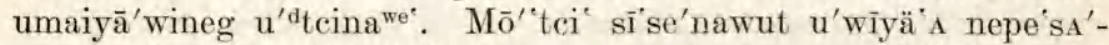

15 megu. TAgā'wigä'i kā'kī'ke'nawute nepe'ss'megu. Kā'kĩ'kīnsme-

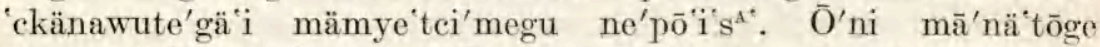
mīgātīwi'ai'yōweni, me 'cena' megu tcāgi' se 'swa'tanä's". Pe'kwi-

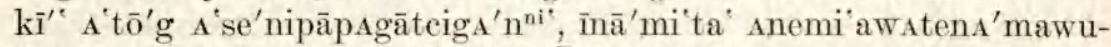

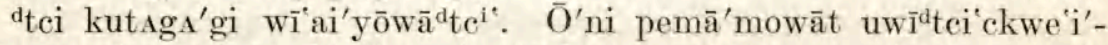

20 nawagi, maninā'mi ta'i pepigwä cku'gi sō'gi täg ane'kī' i tagwa'tameg ō'ni mani'megu'u ma ckimu'täegi' sō'gi'täg ane'kī' 'i'. Inā'-

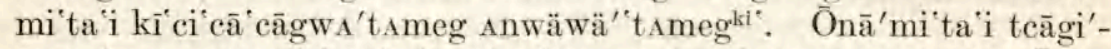

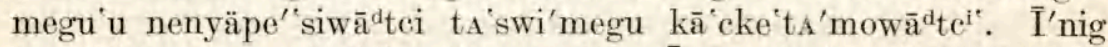

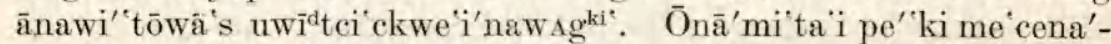

25 'megu keginä's anemikīckī'gwä eu de înig uwīdtci ckwe i'nawA$\mathrm{g}^{\mathrm{ki}}$.

$\bar{O}^{\prime}$ ni mō'ki tā'gäwät āmi' cawigki'. Ms'ni mī'cām āpi ckwi'ss'-

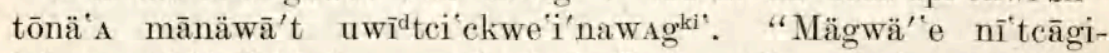

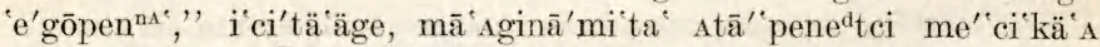

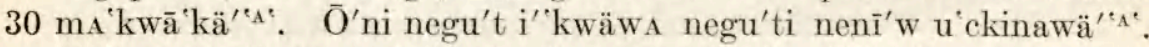

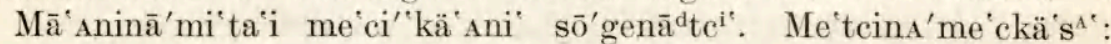

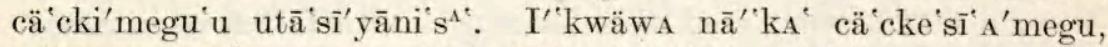

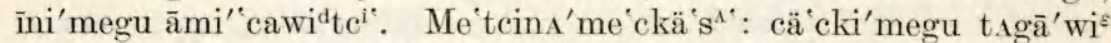

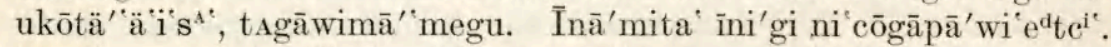

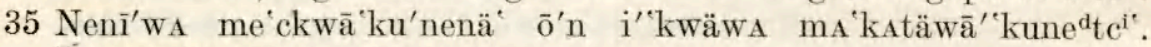

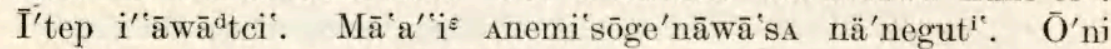

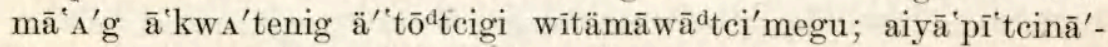
ip Anemiwitegō'mowā' $\mathrm{s}^{\Lambda^{*}}$ Kī'pene ${ }^{\prime}$ megu A'cäyā'monit īni'megu A 'cäyāmoni"sapi. $\bar{O}^{\prime}$ ni wäpipa ${ }^{\prime \prime}$ onite kī̄pene nānānōdtcime'gupi

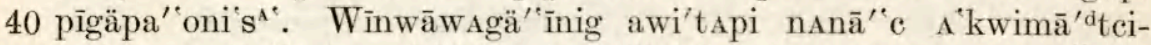

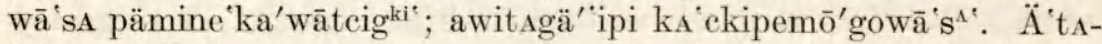

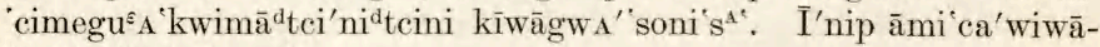
de ín i'ca'wiwete:

2 This is the real meaning, but it is not a literal translation. 
water the same befell him. That, it is said, was why it was against their religion for him to be given water to drink. Only after they had smoked were they given medicine to eat. This had small roots: they were given a very little to eat. Then, it is said, they separated. Then at any time they began drinking water. Only, it is said, they whose shinbones or whose bones had been broken ${ }^{1}$ limped when they walked. And as for those whose hands were broken, it is said that nothing was the matter with them. Only it is said that the bones of some were crooked. And it is said that some had lumps on the joints; they only had small lumps on the joints, not large ones.

Now as to what happens on the warpath or when fighting. This (medicine) which is tied to the bag is cut off; it is spat with a shower on the arrowhead; likewise the bow is spat upon; and the right hand. If any one were even grazed (by the arrow) he would die. And if he were scratched a little he would die. If he were scratched on the skin he would surely die. And if there were plenty of war implements, all would be spat upon without exception. If there were a war club or stone hammer, others would continue to be handed them to use. Now if the enemies fled, a little of this which is tied to the flute was to be chewed together with a little of this which is tied to the bag. After this was chewed (the flute) was blown. Then as many as heard it would all become excited. Those enemies would be unable to move. The heads of those enemies would continue to be cut off while they were still alive.

And this is what happened if they [the enemy] made a sudden assault. This sacred pack would be suddenly untied if the enemies were numerous. If it were thought, "Perhaps we shall all be killed," these would be taken out, the snapping turtle and the tortoise. And (there would be) one woman and one man, a youth. (The latter) would hold this snapping turtle in his hand. He would be naked: he would only have his breechcloth. And the woman, indeed a virgin, did the same. She would be naked: she would only have a little skirt, a very little one. They would be made to stand as a pair. The man would be painted red and the woman black. They started off. They would take.these (the snapping turtle and the tortoise) along in their hands, each taking one. Those who had weapons accompanied them; it is said they would hoot as owls once in a while as they went along. If, however, (the enemy) should retreat in their flight, they would run themselves to death, ${ }^{2}$ it is said. And if they were to begin to run, it is said they would run aimlessly till tired out. They, the ones pursuing them, would never become exhausted in the chase; nor, it is said, could they be shot. The place where the others became exhausted in the chase was where they were laid. That, it is said, is what would happen to them if that were done. 
$\bar{O}^{\prime}$ ni nā'kA'dtci magA'tägege sī'pōw īni'megu āmi'ca'wigki' : negu-

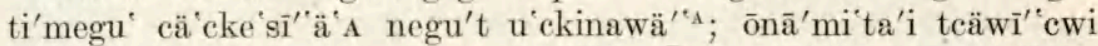

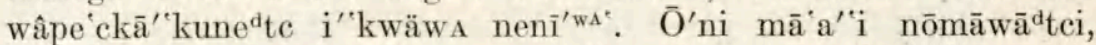

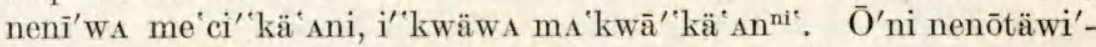

5 ne sä'māwani me'sōtäwe' 'mega me to 'säne'niwagi' sōgenāwā's $\operatorname{sap}^{\mathrm{i}}$.

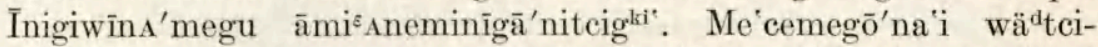
megu'u pagaiyā'cowī'gwä'ig āmitcs'kwitemyā' ${ }^{\prime}{ }^{\prime}{ }^{\prime}{ }^{\mathrm{ki}}{ }^{\circ}$. Awi'tapi

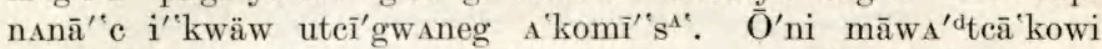

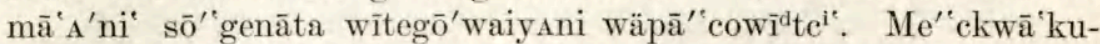
10 no'sapi nenī'wA'. Kï'cimegutcāgāwA'netīnite māwA ${ }^{d}$ tcā'kowi'megu

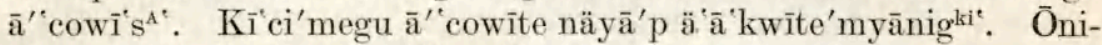
pimegā'mita“i kī'gänugki'. Cewä'napi me'sōtäwi'megu wĩ'se'-

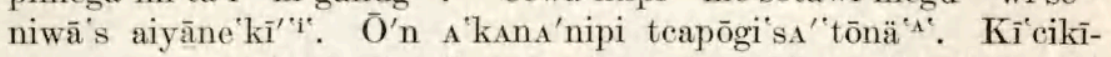

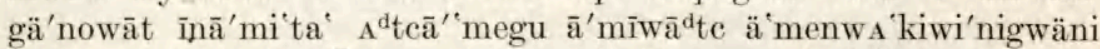

15 mawipō'nīwādte ${ }^{\mathrm{i}}$. Inigä 'wī'nA' cä cki'megu ä'tA ci' Agwaiyā co'-

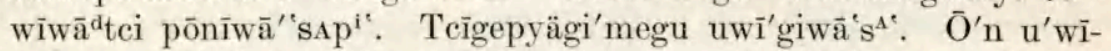
yä ${ }^{\prime A}$ penō'dtci mawi'pōnīte kägō $\bar{o}^{\prime \prime}$ megu $\mathrm{i}^{\prime \prime}$ cawi $\mathrm{s}^{\wedge}{ }^{\prime}, \bar{o}^{\prime}$ me cegä ${ }^{\prime}$

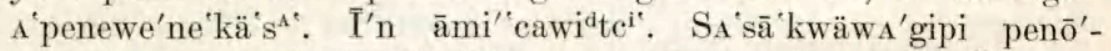

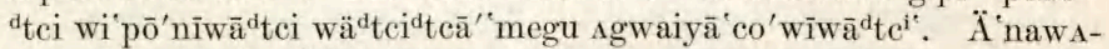

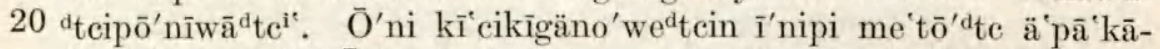

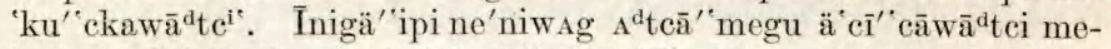

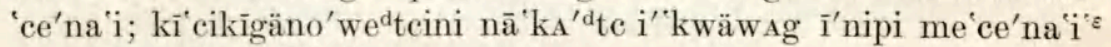
ä'wäpimane"säw $\bar{a}^{\mathrm{d}} \mathrm{tc}^{\mathrm{i}}$.

$\bar{O}^{\prime}$ ni käteminawe'si't ä" cawidtci". "Ma'katäwi'A'nagwäwa," i ci-

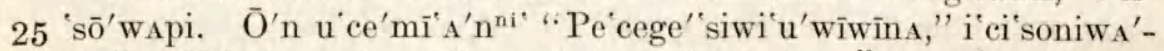

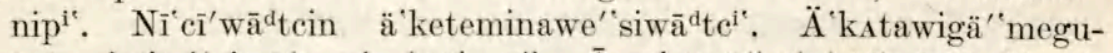

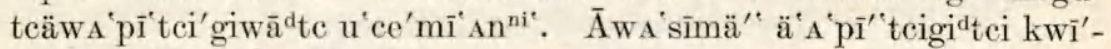
ye'sä' i ckwä'sä's $\Lambda^{\prime}$ tenā'wi'.

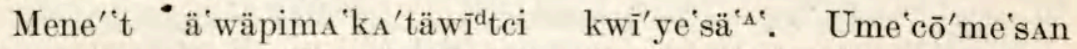

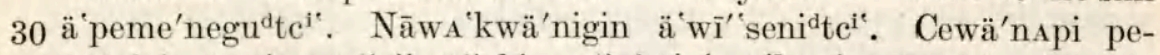
pō'nigin āgwinanā' ci' cä "ckigwä' $\mathrm{e}^{\mathrm{d}}$ tcini nā kanipepō'n ${ }^{\text {we'. A }}$ A penä-

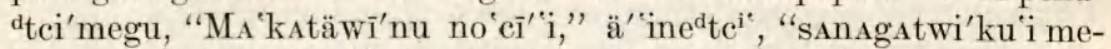

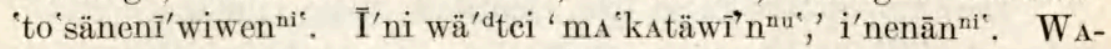
nimō'dtei mō'ci'tōyane wī'Anemiwīidteime to sänenī'gäyan ${ }^{\text {ni'. }}$. Me-

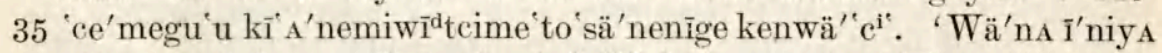
tä'pwägwäni neme'cōme`sa,' kĩi'citä'e pete'g äcinene'känemī'-

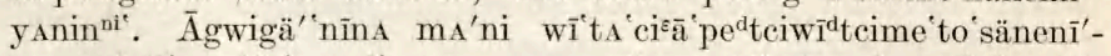

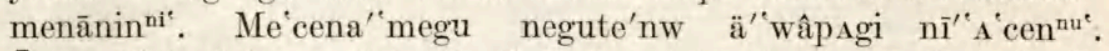

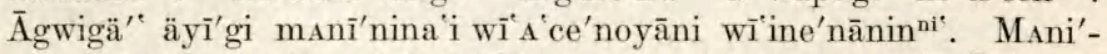

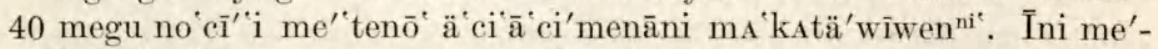

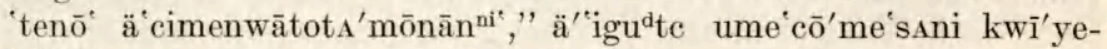
'sä ${ }^{\prime}{ }^{A}$. 
And also if there were a wide river the same would happen: (there would be) one virgin and one youth; they would both, the woman and the man, be painted white. And they carried these on their backs, the man carrying the snapping turtle, the woman the tortoise. And it is said that all the people would hold Indian tobacco in their hands. Now these (the woman and the man) would be in the lead. Wherever they just waded would be shallow. It is said that the woman would never be in water above her knee. And the one who held this owl skin began to cross the farthest in the rear. It is said that the man would be painted red. After all had gradually gone he would cross farthest in the rear. After he had crossed immediately (the river) became its natural depth again. ${ }^{1}$ And then it is said that there would be a gens festival. But, it is said, every one would eat a little. And the bones would be thrown into the water. After they had held the gens festival they might move to wherever there was pleasant land and camp. Now it is said that they would camp only where they had crossed out of the water. They would live on the edge of the water. And if any one should start to camp far away, something would happen to him, (or) he might get some disease. That is what would happen to him. It was against their religion for them to camp far away from where they had crossed and (came) out of the water. They stopped to camp. And after the gens festival was held it is said it was just as if they had been dismissed. Then, it is said, the men went hunting any place; after the gens festival was held then also, it is said, the women began to cut wood anywhere.

Now as to what happened to the one blessed. It is said that "Black-Rainbow" was his name. And his niece (sister's daughter) was named "Deer-Horn," so it is said. They were both blessed together. He and his niece were nearly of the same age. The boy was somewhat older, and the girl less.

First the boy began to fast. He was taken care of by his grandfather. At noon he ate. But, it is said, throughout the entire winter he was never allowed to go with his face unblackened. Always was he told, "Blacken your face, my grandchild, life is hard. That is why I say to you, 'blacken your face.' You might even have a vision as to how you will continue to live with the people. For you will continue to live long with the people. 'I declare, that grandfather of mine must have spoken the truth,' you will think, when you think backward of me. For I shall not live forever with you here. Some day I shall disappear. Moreover, I shall not now tell you when I shall disappear. This, my grandchild, is only why I thus teach you about fasting. That is only why I speak kindly to you," the boy was told by his grandfather. 


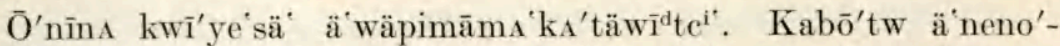

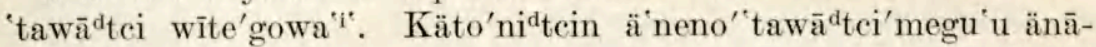
${ }^{\mathrm{a}}$ tei'moni ${ }^{\mathrm{d}} \mathrm{ci}^{\mathrm{i}}$.

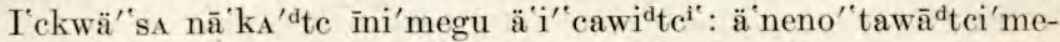
5 gu wite'gowa ${ }^{\prime \prime}$.

$\bar{O}^{\prime}$ ni kabō'tw ä Anā'gwinig ä ke'tonidtci wîte'gowan" ni", "Aiyō's -

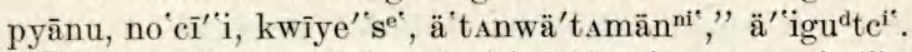

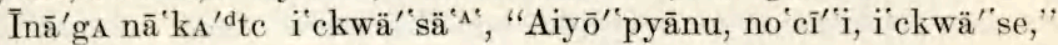
ä $^{\prime}$ 'igudtci teäwīna" megu'u.

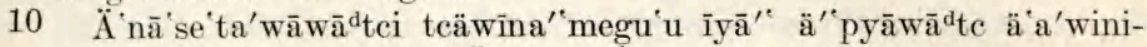

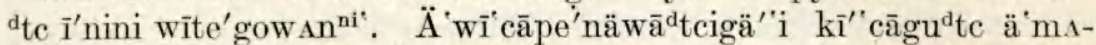

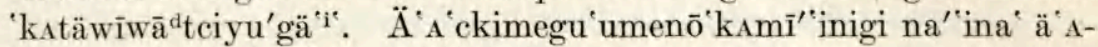

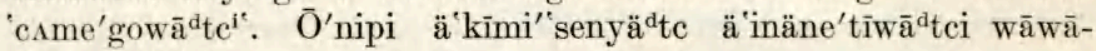
'tei'megu'u'.

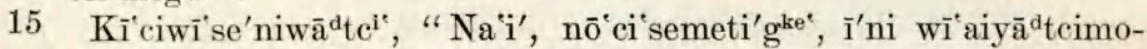

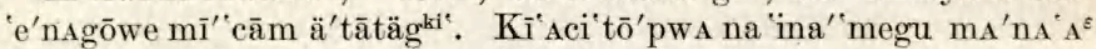

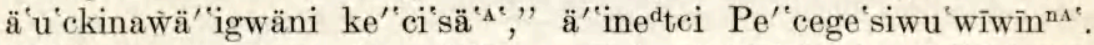

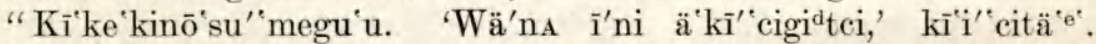

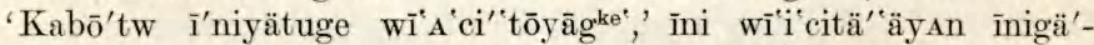

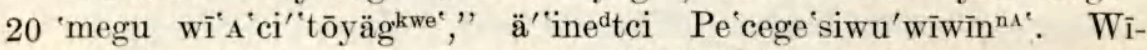
nagä' 'ina Ma 'katäwi' A'nagwäwa, "Kī'ke'känetakudtci'megu'u na'-

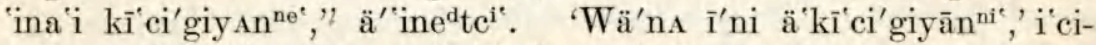

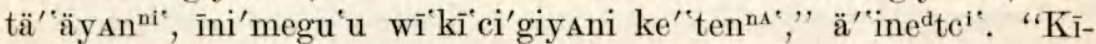

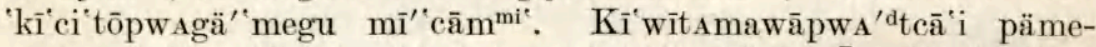

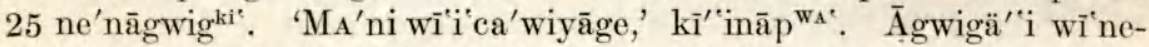
'ckime'nāgwinn ni". 'Cī! Kakatānī'iyo,' - kī'igōpwa'megu'u. Nā'kA'dtc i'nugi nī'nA ä'A 'cAme'nagōw a ditci'moyägw āgwimegu'u

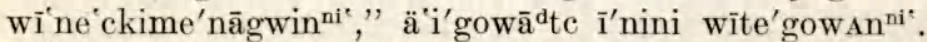

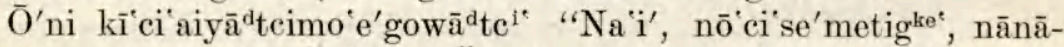

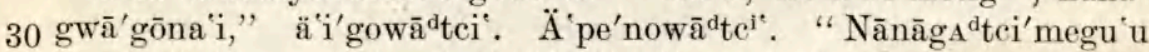

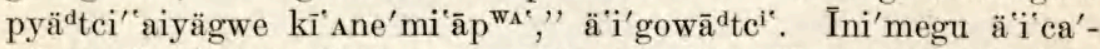

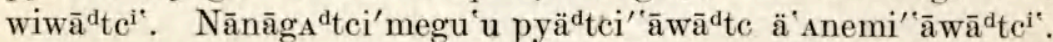

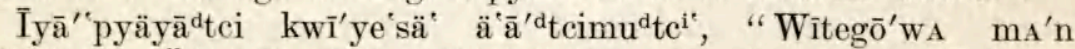

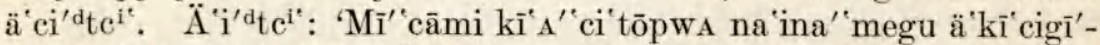

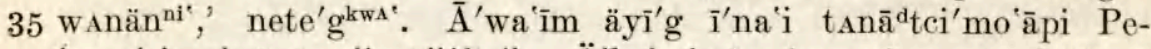

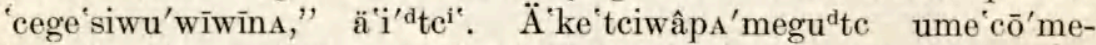

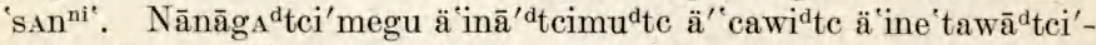

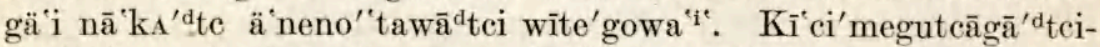

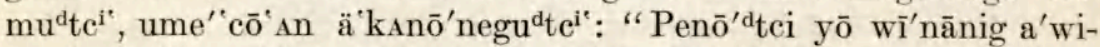

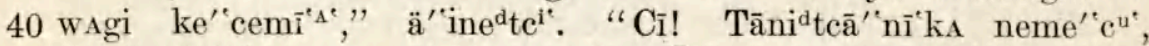

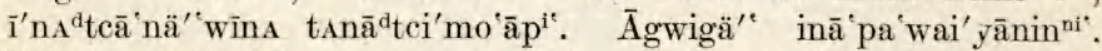

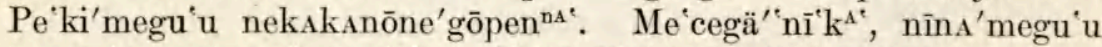
newāwāwanänetā'petugke". A'sā'mi wä'nāgkwi'," ä' ${ }^{\prime}$ inādtc ume'cō'me'sAn ${ }^{n i}$, "Na'i', no'cī'i' manetōwa'ku'i kenene'käneme'- 
Then that boy began fasting. Soon he understood the owls. He understood what they said when they hooted.

And the same happened to the girl: she understood the owls.

And soon in the evening when an owl was hooting, he was told, 'Come here, my grandchild, boy, where I am hooting.'

Likewise yon girl was told at the same time, "Come here, my grandchild, girl."

They set out toward the sound and arrived at the same time where that owl was. They were extremely hungry, for they were fasting. It was in the early spring; then it was that they were fed. And, it is said, when they ate secretly they thought of each other because (the grandparent did not know it).

After they had eaten, they were told, "Well, my grandchildren, now I am going to tell you about what is called a sacred pack. You shall make one whenever this your uncle (mother's brother) shall be a young man," Deer-Horn was told. "You will keep track (of the time). 'I declare, he has grown up,' you will think. When you shall think, 'We shall probably make it soon,' then indeed you are to make it," Deer-Horn was told. As for that Black-Rainbow, "You will indeed know when you are mature," he was told. "When you think, 'Well! I have grown up,' then you will surely be grown up," he was told. "You will (both) make the sacred pack. Verily you will tell those who take care of you. 'We are to do this,' you shall tell them. They will not forbid you. 'Well! Very good,' you will be told. Moreover if you relate that I fed you to-day, indeed you will not be scolded," they were told by the owl.

And after they had been given the discourse, "Well, you may each depart, my grandchildren," they were told. They went home. And they were told, "You will continue (back) on the way you came." They did precisely that. They continued (back) on the way they came.

When the boy arrived yonder he related, "This is what an owl told me. He said: 'You (pl.) are to make a sacred pack whenever you (sing.) shall be grown up,' he told me. She, Deer-Horn, was there and was told at the same time," he said. His grandfather looked intently at him. Then he narrated exactly what had happened to him, how he heard and understood owls. After he had related all, his grandfather addressed him: "Your niece (and her people) live far awav," he was told. "I declare! Grandfather, she was there and was told at the same time. I was not dreaming. We were spoken to a great deal. May be, egad, I completely have forgotten it. But truly it is not so," he said to his grandfather. "Well, my grandchild, 


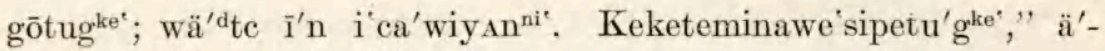
"inā te ō'ci'semani pa 'citō' ${ }^{\prime \prime}{ }^{\prime}$ '.

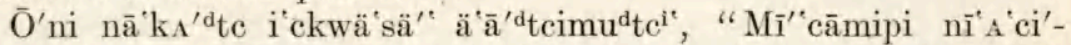

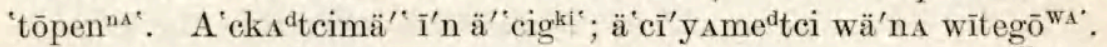

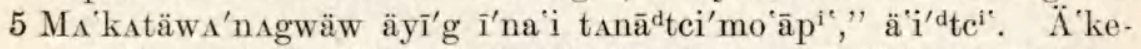
'tciwấpame ${ }^{d} \mathrm{tc}^{\mathrm{i}}$. "Penōdtcimā'

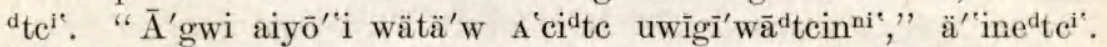
"A'sāmiwä'nA ina'nä'wīns tA cipe'se cäwA'," ä'idtci'megu.

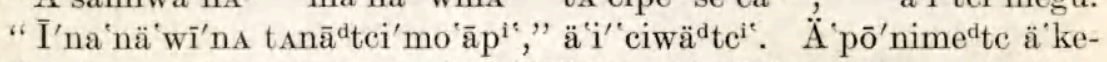
10 'kye tenāme tawu ${ }^{\mathrm{d}} \mathrm{tci}^{\prime} m e g u$ 'u. Kabō'tw ä pō'nime ${ }^{\mathrm{d}} \mathrm{tc}^{\mathrm{i}}{ }^{\text {' }}$.

$\bar{O}^{\prime}$ nipi pe ki'megu äwīeigima katä'wīmed tci tcäwī' $\mathrm{c}^{\mathrm{wi}}$. Kabō'tw

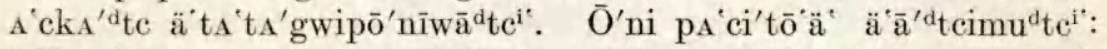

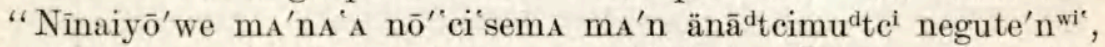

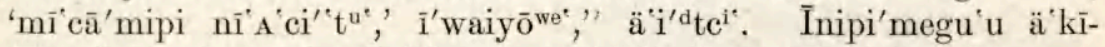

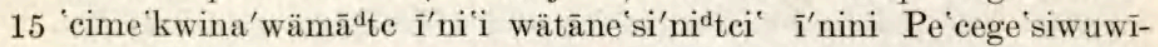

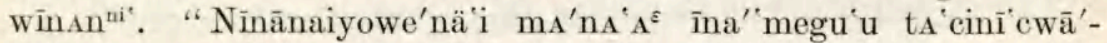

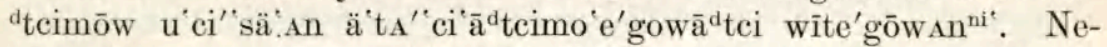

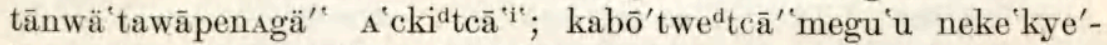
'tenāmine ta'wāpen ${ }^{\mathrm{nA}}$.". $A^{\mathrm{d}} \mathrm{tca}^{\prime}{ }^{\prime}$ megu ä'manetowä'nemed $\mathrm{tc}^{\mathrm{i}}$.

$20 \mathrm{Pe}^{\prime \prime} \mathrm{k}$ ini'g ä'ma kwāte'siwa $\bar{a}^{\mathrm{d} t c i g a ̈ a^{\prime} \mathrm{i}^{\prime}}$. I'naiyo $\overline{\mathrm{I}}^{\varepsilon} \mathrm{i}^{\prime \prime} \mathrm{kwäw} \bar{a}^{\prime}$ gwipi

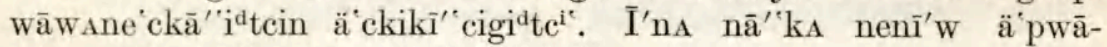

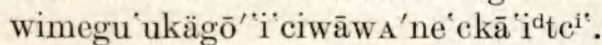

O'nipi me cena" ne'gutenw äcegicegi'cig A te'tc ä'ma'katäwīdtcigä' i kabōtwe'megu'u änene'ki'tä'äde ${ }^{i}$, "Cīnäpe' aiyōwe

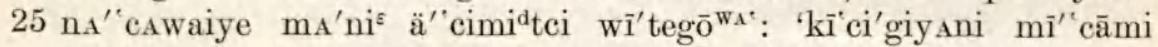

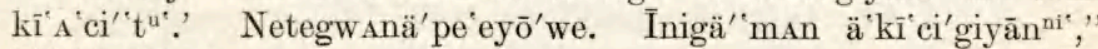
äici'tä ädtc ${ }^{i^{\circ}}$.

I'niys nā'kA'dtci cä'cke`sī's kabōtwe'megu äyä'ci`s ci tōotci

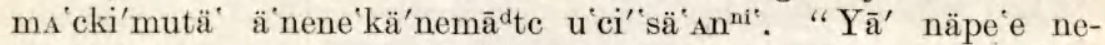

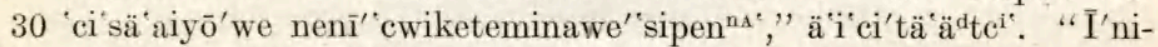

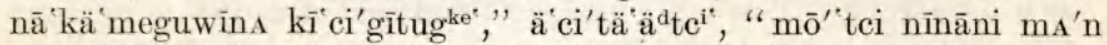

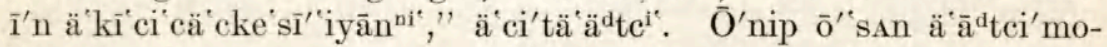

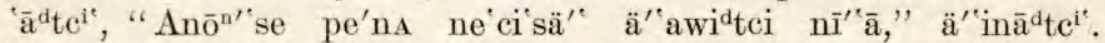
"Au'," ä'inedtc $c^{i}$. I'tep ä $\bar{a}^{\prime d} t c^{i}$.

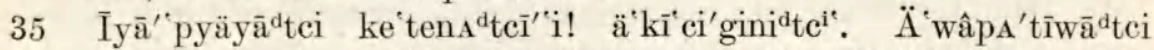
tcäwina'megu'u. "Yā inïwä'megu'u pe’ $k$ ä'kī'cigidtci ne ci-

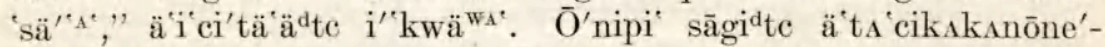

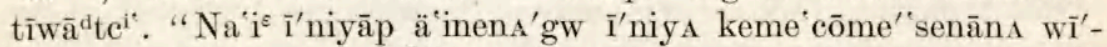
tegōwa na ina' megu. 'Ä'kīci'gigwännic,' kete'gwaiyōwe. Inidtcā'-

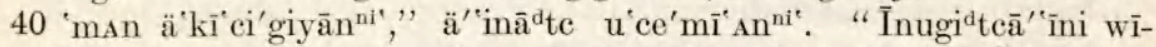

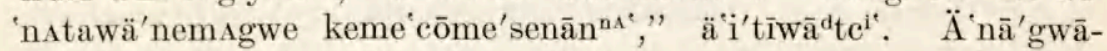

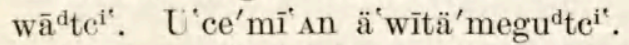

A te tcimä'i kīci'pyāwādtc änä'wāwāatci néniwan äme tci-

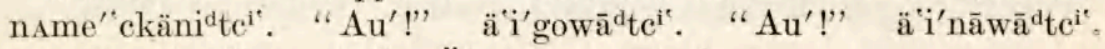

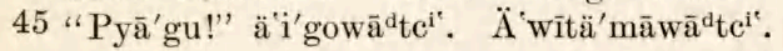


a manitou has probably thought of you; that is why that has happened to you. You are probably blessed," the old man said to his grandchild.

And likewise the girl related: "It is said that we will make a sacred pack. Later on is when it will be; that is what the owl told us. Black-Rainbow was also there and was told it at the same time," she said. She was looked at attentively. "Your uncle [mother's brother] (and his people) live truly far off," she was told. "They do not live near here," she was told. "Truly he listened there," she said. "He was there and was told about it at the same time," she said. They ceased bothering her as they were convinced by her. Soon she was bothered no longer.

Then it is said that they were both made to fast earnestly. Later on soon they camped together. Then the old man related: "This grandchild of mine a while ago once related, "it is said that I am to make a sacred pack,' he said a while ago," he said. Then, it is said, he thereby made those, whose daughter Deer-Horn was, mindful (of what she had said). "This (daughter) of ours a while ago related of the two what she and her uncle had been told there by the owl. At first verily we did not believe her; but soon indeed we were convinced of what she said." And they were surely thought to be manitous.

They were very quiet. That woman, it is said, was not bad when she first grew up. Likewise that man was in no way bad.

Now, it is said, once as he was lying down somewhere afar off while fasting, he thought, "Well, this is what the owl said to me a long time ago: 'When you are grown up, you are to make a sacred pack.' He told me long ago. Now indeed is when I am grown up," he thought.

Likewise that virgin as she was still making a bag soon thought of her uncle. "Well, we two, I and my uncle, were blessed long ago," she thought. "Now indeed he must be grown up," she thought; "even I have now become a young woman," she thought. Then, it is said, she said to her father, "Father, let me go where my uncle is," she said to him. "All right," she was told. She went thither.

When she arrived there, lo! he surely was full-grown. They looked at each other at the same time. "Oh, indeed, my uncle is now very much grown up," the woman thought. Then, it is said, they talked to each other outside. "Well, eventually, what that grandfather of ours, the owl, said to us (has come to pass). "Whenever he shall be grown up,' he said to you in the past. Now indeed I am grown up," he said to his niece. "To-day indeed we shall expect our grandfather," they said to each other. They departed. He was accompanied by his niece.

After they came to a lonely spot they saw a man who was naked. "Hello!" they were told. "Hello!" they said to him. "Come!" they were told. They accompanied him. 


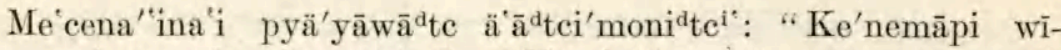
'nena'wiyägwe," ä'i'gowăde ${ }^{\mathrm{d}} \mathrm{i}^{\mathrm{i}}$. "Ninaiyō'we wìtamō'nagōwe mī'-

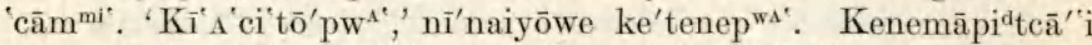

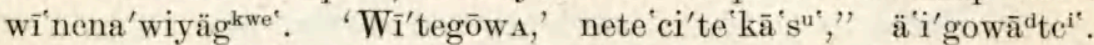

5 "Manigä' ä ci'giyānni'," ä'i'gowādtci'. Ke tens'megu'u wìte'gowan änä'wāwā $\bar{a}^{\mathrm{d}} \mathrm{te} \mathrm{i}^{\mathrm{t}}$.

$\bar{O}^{\prime}$ nip $\bar{i}^{\prime} \mathrm{n}^{\mathrm{nA}}$, "Nō'ci'semeti'ge keketeminōne' $\mathrm{p}^{\mathrm{wA}}$. $\overline{\mathrm{A}}^{\prime}$ gwi kägōo ${ }^{\prime \prime}$ i'cimyāne'tegin ä'inäneme'nagōwe'. Ä ci'megu ume'nwigeg $\overline{1}^{\prime} n$ ä'inäneme'nagōwe'. Ä'snemi ämigA 'ki'megu'u keme to 'säneníwiwen-

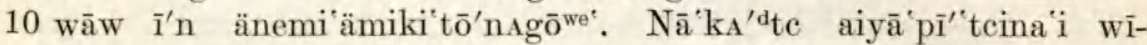
'Anemitäpī'kā'noyägkwe': īni'megu'u änemi'ciketeminō'nagōwe'. Cewä'nA kā'ta, nō'ci'se'metigke', ā'ci'tA nene'känetamawī'yägägu kĩdtcime to'säne'niwāwa kī'citäpi'ägwini kägō' ${ }^{\prime \prime}$. I'ni nī'nA cä'ck ä'cime'nagōwe'. Ō nīnagä'megu'u nīya'wi kī`A ci'tci'gäwä-

15 pwa, nī'nskudtci keketemi'nōnep ${ }^{\mathrm{wA}}$, āgu'wīyä'A. Cewä'nA nīnn $\bar{a}^{\prime}$ gwi ne ${ }^{\prime} i^{\prime} k^{\Lambda^{\prime}}$. Mand ${ }^{\prime \prime} k A$ näna ä'netaga keme to säneniwī'wenwāw

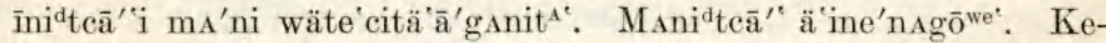
keteminōne'pw äine'nAgōwe:. I'́nA nīgānīt ä'ketemi'nōnāgkwe: Cewä'n A'penädtci'megu'u kĩnene'känemi'pwagä ${ }^{\prime}{ }^{*}$. Ka $\bar{a}^{\prime} t_{A}$ pagi-

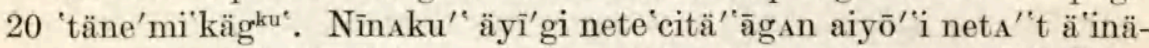

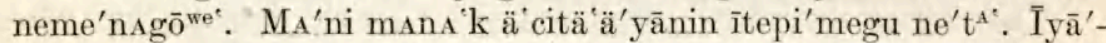

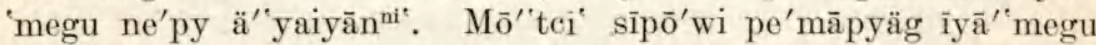

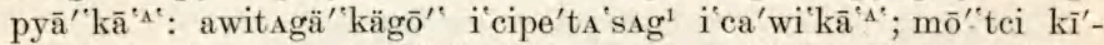

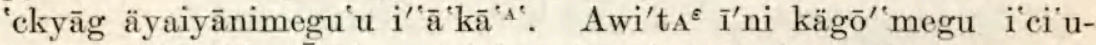

25 tami 'e'gwi ka ${ }^{{ }^{\prime}{ }^{\prime}}$. O O'ni mA'ni kīnwā'wA' sīpō'wi pe'māpyäg utami-

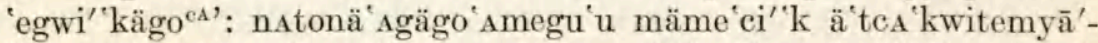

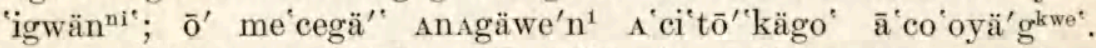
Awi'tA ${ }^{\varepsilon}$ ini'megu'u i'ci kegenipya $\bar{a}^{\prime \prime} k a ̈ g o{ }^{\prime} A$ : inni'megu'u āmita cipe-

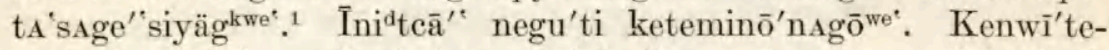

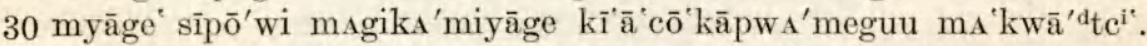
"Ō'ni nā'kA'dtci myā' 'ke'sut u'wyä'A kī'nä'sä'āpws'megu'u. $\bar{A}^{\prime}$ gwi wīpwāwinä 'sä' ägwini, cewä'nA me'tenō' ${ }^{\prime}$ megu mamātome-

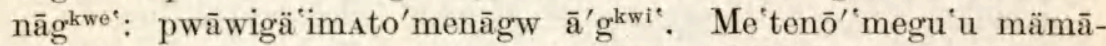

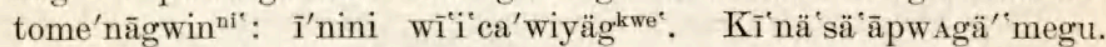

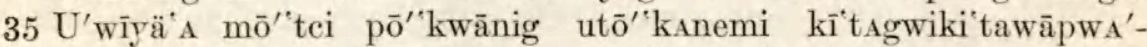

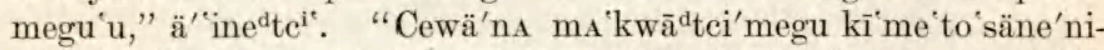

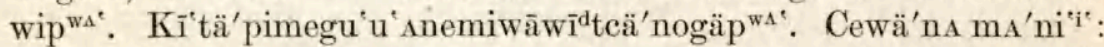

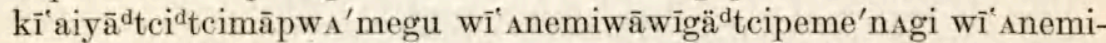

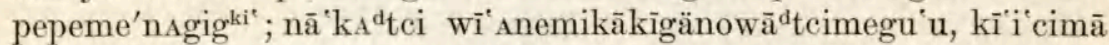

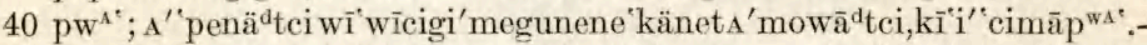

" NAgA'mōnani kī'gänōni, kī'ke'kä'netāpwa ku'dte ìni kī'gänōn

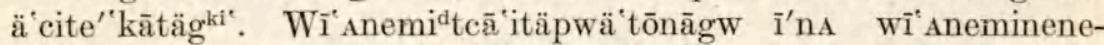
'känetā'gu'sit aiyō' ${ }^{\prime} \mathrm{u}^{\mathrm{d}}$ tci mī' cāmegki'. $\overline{\mathrm{O}}^{\prime}$ wī'pwāwigä itäpwä' tō-

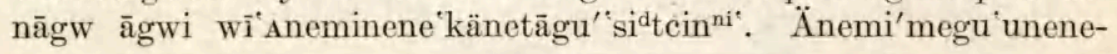


After they had arrived somewhere, he related: "I do not suppose you recognize me," they were told. "I instructed you in the past about the sacred pack. 'You are to make it,' I told you in the past. I do not suppose you recognize me. 'Owl' is what I am called," they were told. "This is how I am," they were told. To be sure, they saw an owl.

Then (he said to them): "My grandchildren, I bless you. There is nothing evil in the way I have thought of you. I have thought of you indeed in a good way. So long as your life shall endure, so long shall I make it go for you. And from time to time you will continue to gladden (the people) by what you do: such is the blessing I shall continue to bestow upon you. But, my grandchildren, do not expect anything in return from your fellow-people whom you have pleased. That is the only (thing) I tell you. And you will use my body, for I bless you, not any one. But it is not I alone. The one yonder who has power over your lives, is he who really plans this. This is what I tell you. I bless you as I tell you. He who is leading one blesses you. But you will always think of me. Do not throw me out of your thoughts. Verily I too have put my thought in here (the sacred pack) when I blessed you. When I think (of going) yonder, I go thither. I arrive at where I am going. Even if there were a river flowing by, I would come there; nothing would go wrong with me; ${ }^{1}$ even if there were a cliff where I was going I should go there. I should not be hindered at all. And you here, you would be hindered if there a river flowed by; you might seek a shallow spot, or you might make a boat ${ }^{1}$ if you crossed. You would not then come quickly: something would go wrong with you there. ${ }^{1}$ That is one way I bless you. If a river is deep and wide, you will easily wade across.

"And again, if any one is wounded, you will heal him. You will not fail to heal him, but only if he prays to you: if he does not pray to you, (you will) not (heal him). (You will heal) only the one who prays to you: that is what you will do. You will heal them. Even if any one's bone is broken, you will heal it together for him," they were told. "But you will live quietly. You will have plenty of time to share it with (others). But (there is) this: you will instruct those who will take care of (the sacred pack) in the future, that each may take extremely good care of it; and you will accordingly tell them that they continue to hold gens festivals with solemnity; and you will accordingly tell them that they always think seriously of it.

"As to the gens festival songs, you will know what is called a gens festival. The one that will-truly continue to believe you is the one that will continue to be blessed by the sacred pack here. And the one who shall not believe you will not continue to be blessed in the future. 


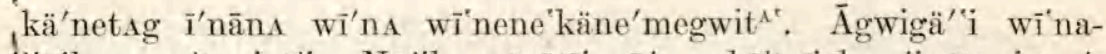

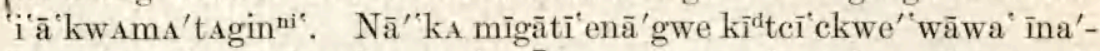

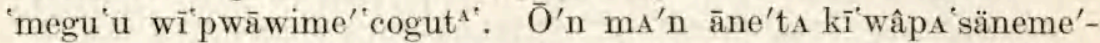

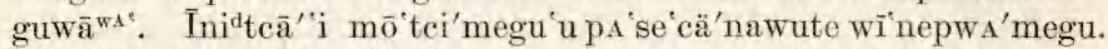

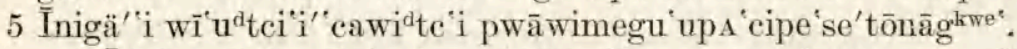

" $\bar{O}^{\prime}$ ni pe'pigwä'ckwi me'sōtäwi'megu ma'netōwa wīk $\bar{a}$ 'cke'tAmwa änwäwä'tA'mägwin ${ }^{\text {ni'. }}$. TA'senwi'megu'u änwäwä'tA'mä-

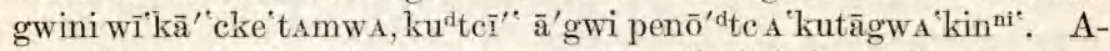

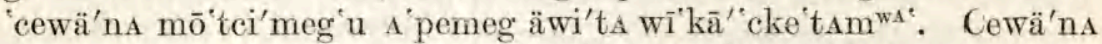

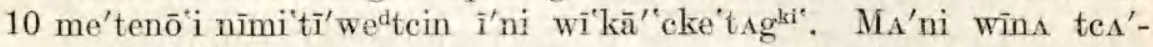

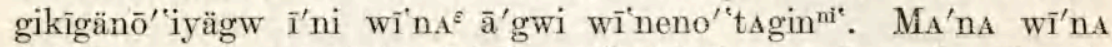

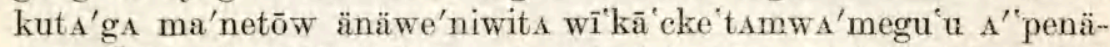
${ }^{d} t_{c}^{i}$. İnidtcā' îni'megu'u me 'tenō äcimānäte'nigini kī'gänōn î́ni wī'kā'cke'tagki'. İniyu'mani me'tenō'i pe'pigwä 'ckwi wĩ wĩ'cigwä-

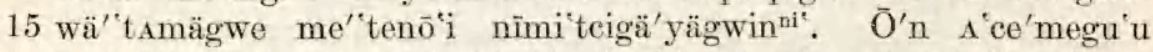

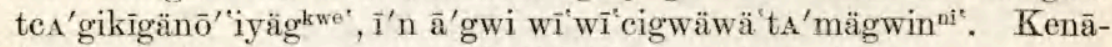

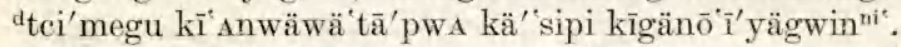

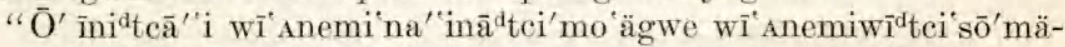

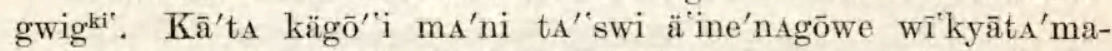
20 wägw inänemī'yägägku'. Me'sōtäwi'ku'i nīnā'n à 'pene'megu'u ke-

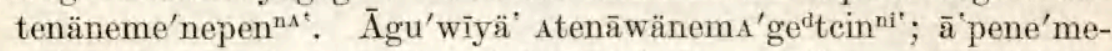
gu'u. 'Tānīna i menwime tờ säneñ̄'wiwāte nō ci'seme'nānagi,' ke-

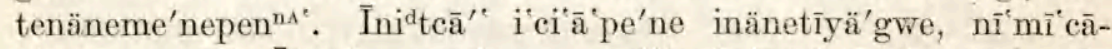
täne'mopen ${ }^{n A^{*}}$. I'́n ä'cagāwā'nenāge wī'i ca'wiyägkwe', ä pene'megu'u

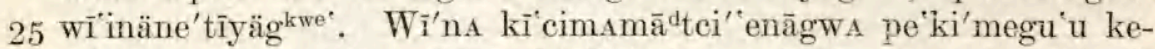

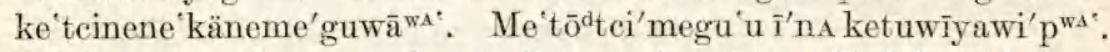

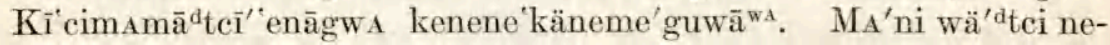
ne'käneme'nāgkwe', unä'mowen innimegōon unä'moweni kenämō'-

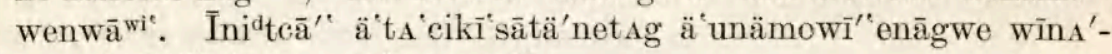
30 megu'u ke'tcinaw unä'mowen ${ }^{\text {ni' }}$.

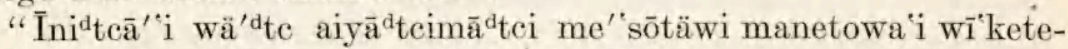

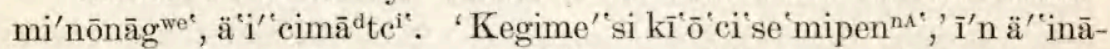

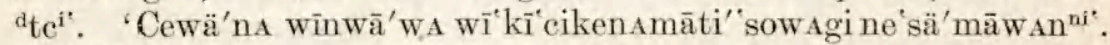
Pe kidtcā'megu'u kīnene'känetama'wāpen ${ }^{n A}$. A A gwigä' äyī'gi wī-

35 'kemōte'māgwini, ku, tcī' i kī'manetō' wipen $^{\mathrm{nA}}$. Cewä'n āgwi kīnā'nA

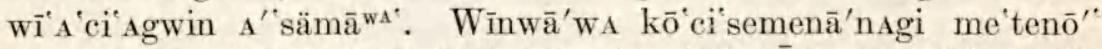

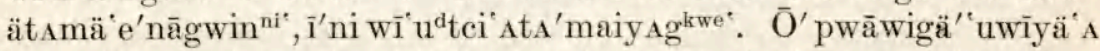

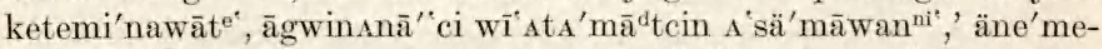
dt $\operatorname{cin}^{n i}$. 'I'nA kīnā'na ta' swi manetowite' $k \bar{a}{ }^{\prime}$ 'soyagwe wi'sanagä'ne-

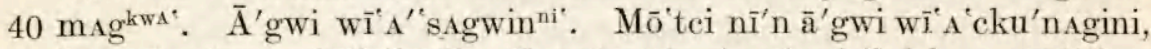

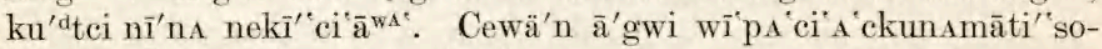

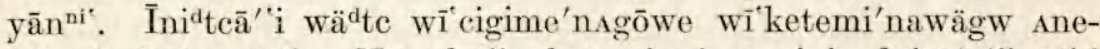

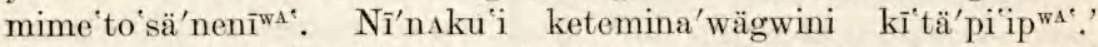
Netegō'penakudtci na' ina“i ma'ni kīcinana āme'ki'se'tōnagw a ' ki 45 wīkīyu'säno'tamagkwe? 
The one that continues to think of it is the one that will be thought of. He will not become sick. Moreover, if your foes fight with you, he is the one who will not be shot. And some will think you funny. Such a one will truly die even if he is hit on the ear. This is why that will happen to him, because he did not listen to you.

"And all the manitous will hear the flute when you blow it. As many times as you blow it, he will hear it, though its sound does not go very far. But even the one who is above will hear it. But he will only hear it when a dance is given. If, now, you hold a small gens festival he will not hear it. But these other manitous, ${ }^{1}$ those who have been mentioned, will hear it always. Truly that (manitou who is above) will only hear it when there is a large gens festival. And you are only to blow this flute loudly when you give dances, only then. Now when you hold small gens festivals, you are not to blow it loudly then. You are to blow it softly when a few of you celebrate a gens festival.

"You shall truly continue to tell that to those who will be of your gens in the future (i. e., generation after generation). Do not think of concealing from them anything that I tell you. We all think of you alike. We think less of no one; (we think of you all) alike. 'Would that our grandchildren lived good lives,' we think of you. Therefore if you thus think the same of each other, we shall be glad. That is what we desire you to do, namely, to think the same of each other. He who made you move, thinks a great deal of you. It is the same as if you had his body. He who made you move, thinks a great deal of you. This is why he thinks of you, your breath is the same as his breath. When he attached his mind to it, he breathed his own breath into you.

"That truly is why he told all the manitous to bless you, thus he told them. 'We shall all have (you) for (our) grandchildren,' he said to them. 'But they themselves shall raise tobacco for themselves. Truly we shall think highly (of receiving) it from them. Likewise we shall not steal it from them, for we are to be manitous. But we shall not make tobacco. Only when they, our grandchildren, offer us a smoke, shall we smoke. And if any one does not bestow a blessing on them, he shall never smoke tobacco,' they were told. 'That (tobacco) shall be something which as many of us as are called manitous shall think difficult (to obtain). We shall not own it. Even I shall not save it, though I made it. But I shall not even save it for myself. That truly is why I firmly tell you to bless the future people. And when you bless them you will please me.' For we were told this at the time when he had placed this earth for you to roam about. 
"Inidtcā' ${ }^{\prime}$ i wädtci'kīnāna nene'käneme'nagōwe'. Na 'ina"megu'u

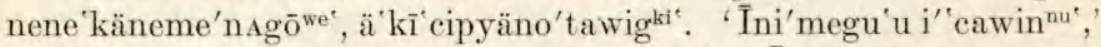
ä'i'c1gki'. 'Keteminawi'megu,' ä'i'cigki'. Inidtcā'nīnA wädtci kĩnā'gwi keteminō'nagōwe'. 'Aiyō'mägwä' $\mathrm{e}^{\varepsilon} \bar{a}^{\prime}$ miwāwudtci'kamā'-

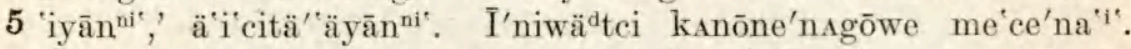
'Īnugidtcă 'in ä'mīne'nıgōwe nīya'wi wī'A 'semi'enagōwegä'nīna

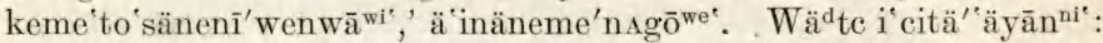

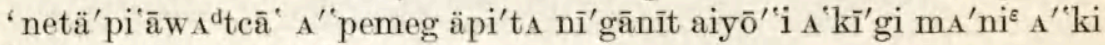
kī'citō'ta ma'netō $\overline{\mathrm{WA}}^{\mathrm{W}}$ ?'

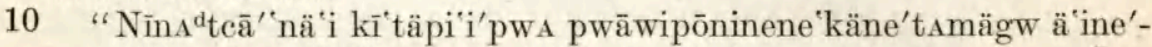

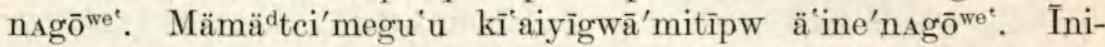

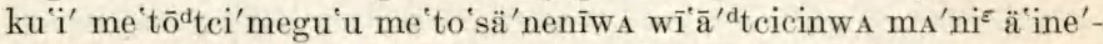

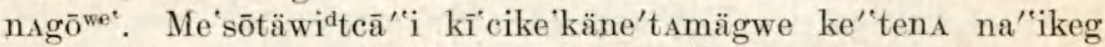

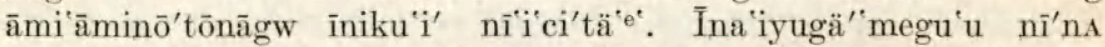

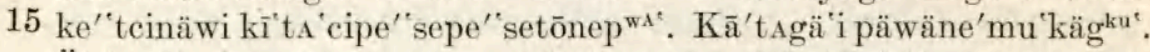
Ä'ckigi'ta wìta'mawägwe mō'tci'megu tA'ciwâpA'cikanō'nenāgwe,

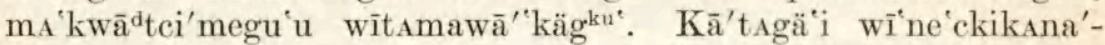

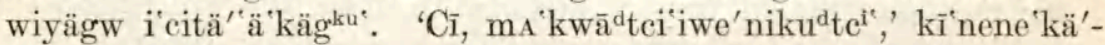
netāp ${ }^{\mathrm{W}}$ :

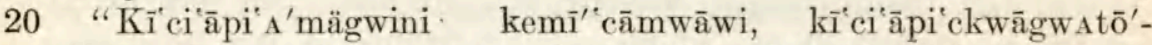

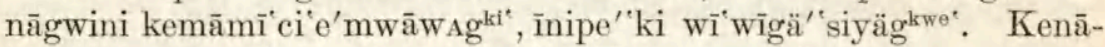
dtcimegō'ni wī'kanōne'tīyä 'gkwe'. Kā'ta nene'känetagägu wī'ne'ckikanōnetīyä'gkwe`. Ä't^ 'swãgwapiwägwä'niku' ä'kīgä'noyägkwe`, īni'megu'u äci'utōtäme'tīyägkwe', ō'n i' ${ }^{\prime}$ 'wäwagi wī'ute'kwämā'-

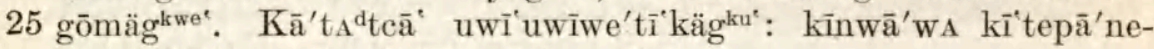

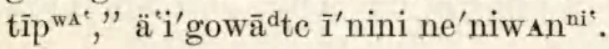

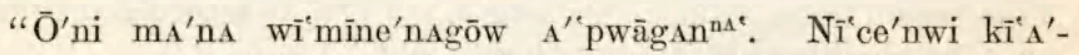
tamāpwa nā'kA'ni penā'we:. Kegime'si'megu'u mA'ni wī'udtci'A-

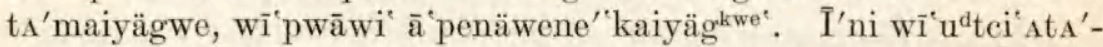

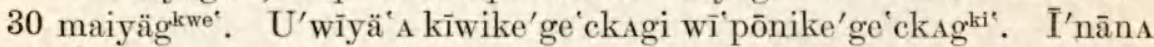

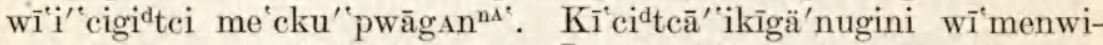

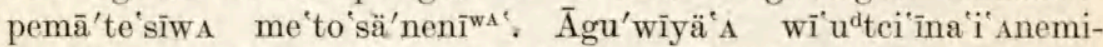

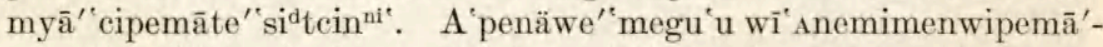

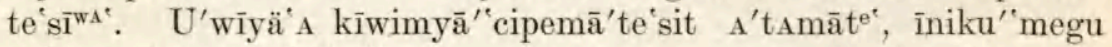
35 wïmenwipemā'te ${ }^{\prime} i^{d} t c^{i}$.

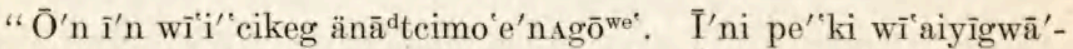
miyägwe wī'wīgädtcinene'käne'tamägkwe: $\quad \bar{A}^{\prime}$ gwi wī'n A'ce nīnA

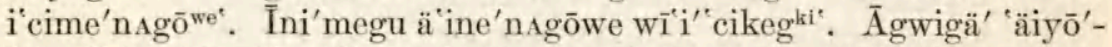
'nīna'i käyädteī'i wĩ keteminō'nagōw inäneme'nagōwe'. ManA 'kA'-

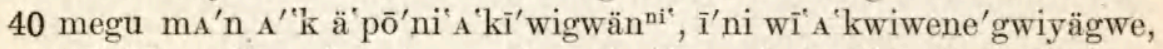

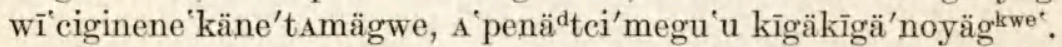

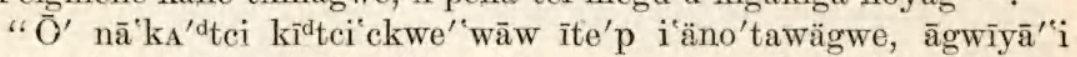

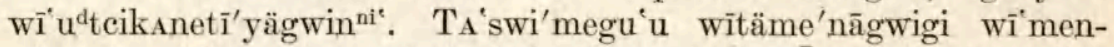
wipyä'wagi kīnwā'wamā' ä'pī'tcinä'säyagkwe`. Ōnī'na ina i kī'ci A- 
"That is why I myself bless you. At the very time I blessed you, he had already come to me. 'Do that very thing,' I was told. 'Pity them,' I was told. That verily is why it was a good thing for me to pity you. 'Maybe that I shall manage to get my smoking here that way,' I thought. That is why I spoke to you. 'To-day I truly give you my body that I may help you in your life,' is what I think of you. (That is) why I thought it: 'I shall please that one who is above, the leading one here on earth, the manitou who created this earth.'

"You will truly please me if you do not cease thinking of what I tell you. You will surely try to obey what I say to you. The people will as if lean upon this which I tell you. Verily after all of you really know it to be a fact, then they will hear us, so I shall truly think. I myself will be close by there to listen to you. And do not think little of it. When you tell the young (people), even if they poke fun at you, you shall tell them quietly. Do not think of speaking harshly. You will think, 'of course quietness is the only way.'

"After you have untied your sacred pack, after your oeremonial attendants have unpacked and laid it down for you, then you must be very careful. You will speak softly to each other. Do not think of speaking harshly to each other. As many of you as sit together when you celebrate a gens festival, just so many shall be as brothers to each other, and the women shall be your sisters. Do not marry each other: (but) you shall love each other," they were told by that man.

"And I shall give you this pipe. You shall smoke it twice during the entire summer. This is why you all should smoke, that you be not afflicted with disease. That is why you should smoke. If any one goes about with it in him, he will cease having it in him. That shall be the power of the catlinite pipe. Verily, after gens festivals the people will be in good health. No one shall go away continuing to be in bad health. He will continue in good health like (the others). If any goes about in bad health, if he smokes, he will straightway have good health.

"Now what I tell you will come to pass. So you must zealously endeavor to carefully think of it. I am not speaking to you for fun. Exactly what I say to you shall come to pass. Nor shall I bless you here for a little while when I think of you. Until this earth ceases to be an earth, is as far as it will take care of you, if you always think seriously of it, and if you keep on holding gens festivals.

"And, moreover, if you go toward your enemy to attack them, you will not leave each other there. As many as accompany you will come (back) happily while we are living. At the time when you 


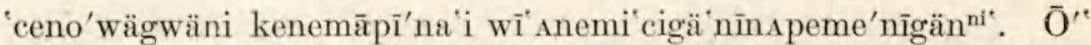
cä ckimeguyätu'gäni wī'Anemipemepemenäweniwä' 'ìyānnit. Kīn-

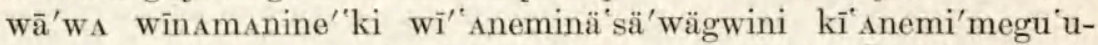

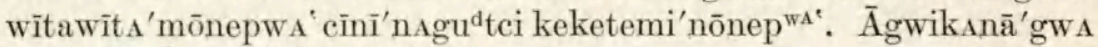
5 wīepwāwād tcimo e'nagōwe'.

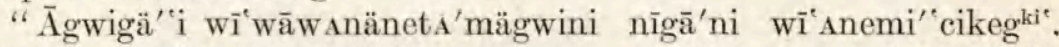
Kīnwāwamā'megu kä'sipi wī'nān änäneme'nagōwe: Kīka'megu me`to'säne'niwagi pämuwī'gitcig ā'gwi wī'wāwanäne'mägwin $\mathrm{u}^{\prime}$ wīyä's nätawine'se'nāgwin ni: . Kīke'känemāpwa'megu

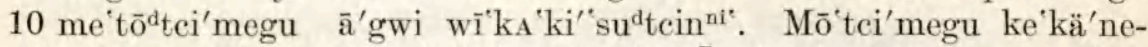

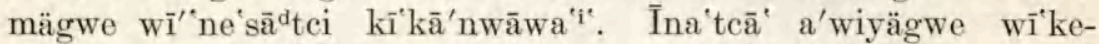
'egwīws'megu. Āgu'wīyä'A wĩ'kA'ckikīmāekō'nāgwini kī̄tci'ckwe" wāwagki". Ō'n i'n i'cike'käneme'nāgwe 'nanato' tōnāgwe me'to'sä'nenīwa kĩ âdtcimo'āpwA'megu, 'mA'ni wädtci ke'kä'ne-

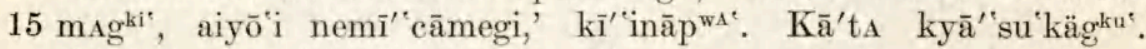

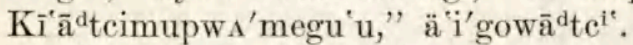

"Ō'ni kīgäno'yägwini wĩute'namägw A"ckutäw aiyō'megu'u nemāte'sä 'egki". Aiyō'megu'u wĩ'ute'namägwe ne'ki'megu'u änemime to 'säneniwi'gwä igkit'. Anemime to 'säne'niwag aiyō'me-

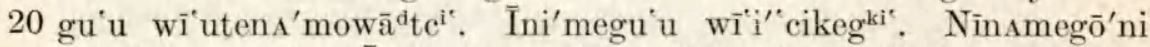

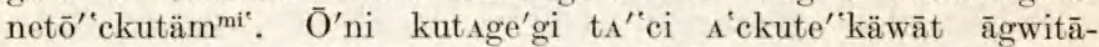

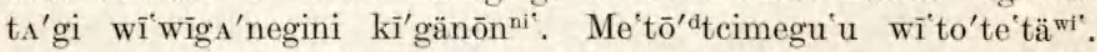

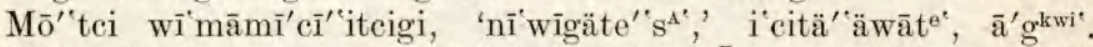

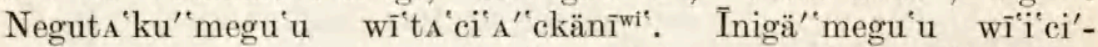

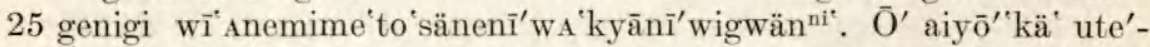

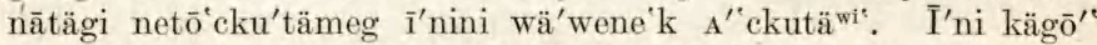

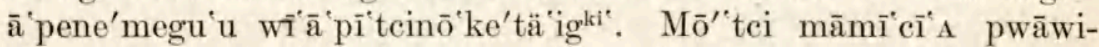
wīgä'te`sıg ā'gwi wī'wīgätetäwi'megu'u. Mā'ma'kāidtei wī'me'nutä ${ }^{\text {wit }}$.

30 " $\bar{O}^{\prime}$ ni ma'ni nā'ka'dtci wīi iei se'tōyägwe ma'ni mīeā'mi kīgä'nugin $^{\text {ni'}}$. A penädtci'megu'u wä'tāpagi kĩi'cigwä' cimāpwa wìte-

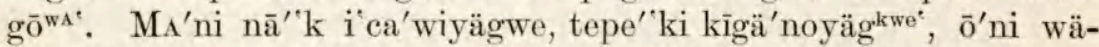
dtcipagi' cimugi wīic igwä' cimägkwe`. MA'ni pe'pigwä ckwi wätāpagi'megu'u kīinānagetunä'setōp ${ }^{\mathrm{WA}}$. Ini'megu'u wĩ i'ca'wi-

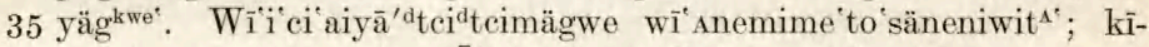

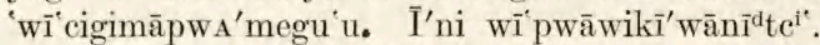

"TA"swi wī'nä'tamägwe mī'cāmi kĩke känetāpws'megu'u.

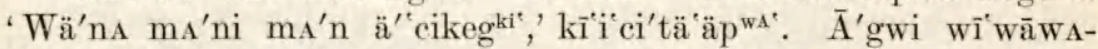
nänet.'mägwin ni'. Mō'tci'megu'u nāta'winōni nä'tamägwe kī'ke-

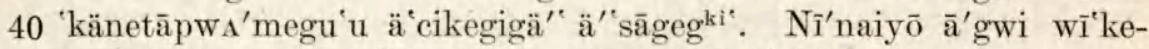
kye'kime'nagöwe'. 'Man̄̄'nini nāta'winōn ${ }^{\text {ni" }}, \bar{a}^{\prime}$ 'gwi wī'ine'nagōwe: Cewä'na na ina' 'megu'u ä'nätamo'wägwäni, ‘wä'ns ms'ni; ma'n

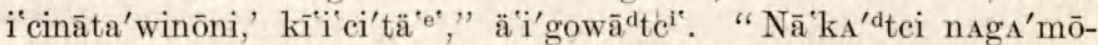

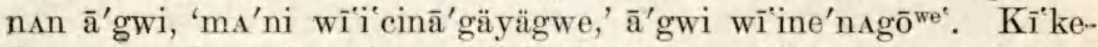
45 'känetāpwa' megu'u wĩ̄Anemi'i cinā'gäyägwe, wĩ̄inānsgetunä'moyä- 
have disappeared (i. e., are dead), I do not know if I shall continue to be taken care of. Perhaps I shall only continue to be taken care of. Yet as long as you continue to live, I shall continue to give instructions to you, for I pity you. I shall not in any way fail to tell you.

"And you will not fail to know in advance what" is to happen. It is only you of whom I think. You will not fail to know if any one of the people who live round about desires to kill you. You will know him just as if he were not hidden. You will even know when he is going to kill your friends. If you are there, he (your friend) will escape. None of your foes will be able to catch you secretly. And if the people know this about you and ask you about it, you will tell them 'this is how I found about him, from my sacred pack here,' you will tell them. Do not keep it secret. You shall inform them," they were told.

"And when you celebrate gens festivals, you shall get fire from my flint knife here. You shall get it from here as long as there shall continue to be mortals. The future generations shall get it from this. That is what will happen. The fire is mine. And if they obtain fire from another, probably the (food at the) gens festival will not taste well. It will be as if raw. Even if those who will serve as ceremonial attendants think, 'I shall cook it carefully,' (they will) not. It will be raw in some places. That is what will happen as long as the earth and mortals shall last. And if it is gotten out of my fire here, that fire will be good. Then everything will be very soft and even. Even if the ceremonial attendant does not attend to it carefully, no matter, it will be cooked,properly. Surely it will be fine.

"And this, moreover, is how you should place the sacred pack in gens festivals. Always face the owl toward the east. And if you do this, if you hold a gens festival at night, you are to face it toward the west. You will customarily place this flute (lengthwise) with one end toward the east. That is precisely what you are to do. You will thus inform the people that will live in the future; you will tell them seriously. Then they will not be lost.

"As many of you as shall see this sacred pack will know about it. 'Well, this is how it works,' you will think. You will not fail to know about it. You will even know the workings of the medicine when you see it growing. I shall not instruct you about it. I will not say to you, 'this is the kind of medicine.' But whenever you see it, you will think, "well, this is it; this medicine is the kind,", they were told. "And as to the songs, I shall not tell you 'you are to sing this way.' You will know how you are to sing them in the future, and (you will know) what to say in speeches. You will know what 


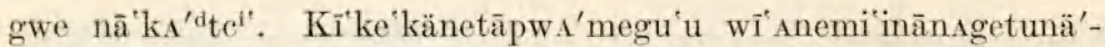
moyägwe, wī'Anemike'kA 'wägigi pī'ta'wi mane'towagki'. $\bar{A}$ gwiyo-

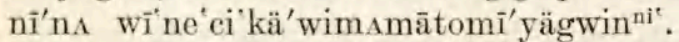

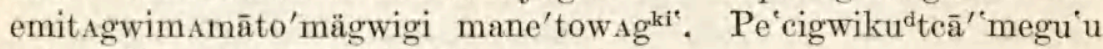
5 wĩnene käne'mīyägkwe"," ä'i'gowä dei.

Kīcetunä'monìtc äpōninä'wāwāddtc ä'spi'spi'nites. Cä'ck

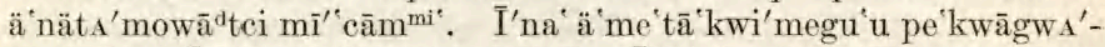

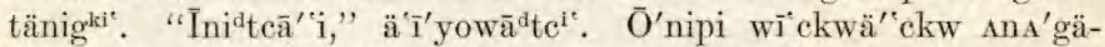

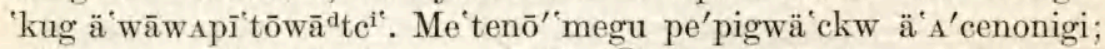

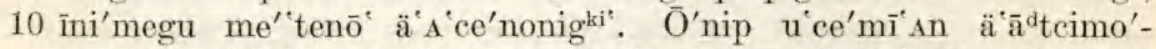

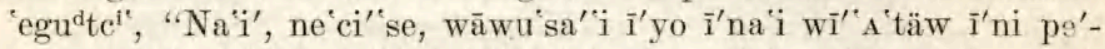

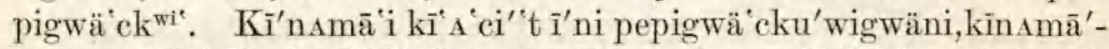

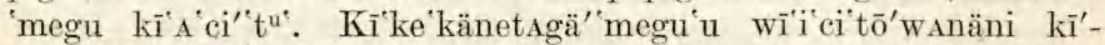

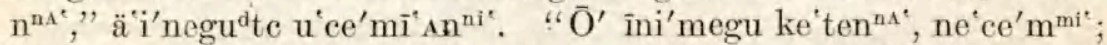

15 ä'me'kwinawä'mīysn ni'. A A gwi'ku' ute'tci nepwā'kai'yānini ne'ce'-

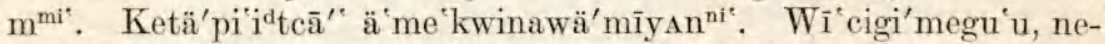

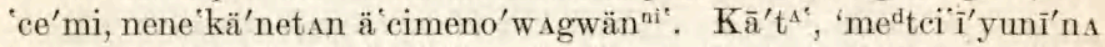

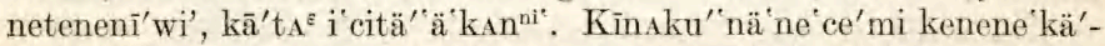

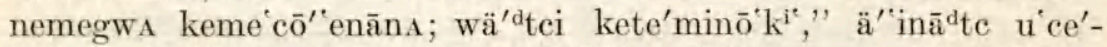

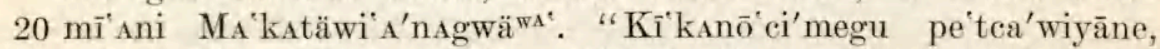

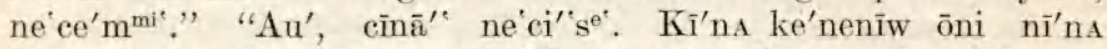

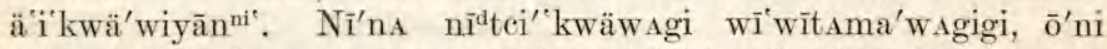

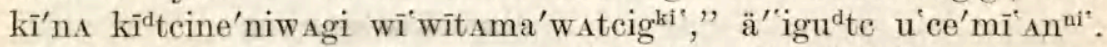
" $\mathrm{Ci}^{\prime} \mathrm{ke}^{\prime}$ tens, ne $\mathrm{ce}^{\prime} \mathrm{m}^{\mathrm{mi}}$, inni'megu i'ca'wi'kani," ä $\mathrm{i}^{\prime} \mathrm{d} t \mathrm{c}^{\mathrm{i}}$.

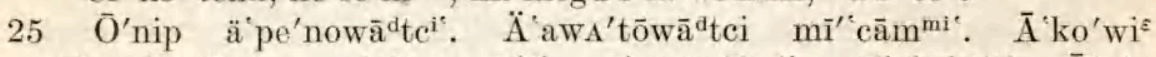

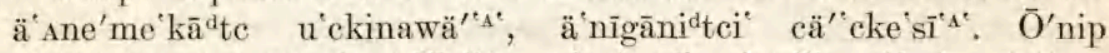

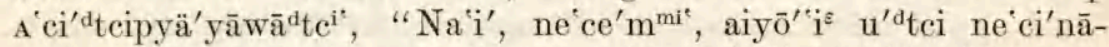

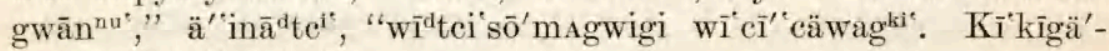

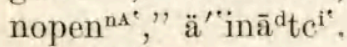

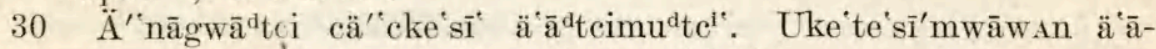

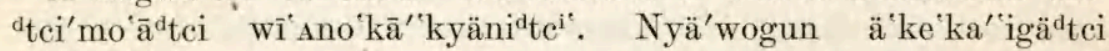
pA ${ }^{\prime}$ cito $^{\circ} \mathrm{A}^{\circ}$.

Ōn̄̄'na mī'cā'mi sō'genaga MA katäwa'nagwäw īni'megu ne' ${ }^{\prime \prime} \mathrm{k}$

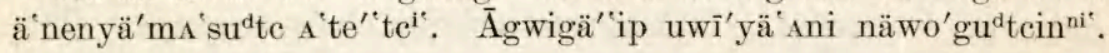

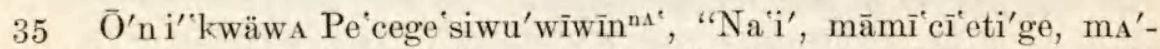

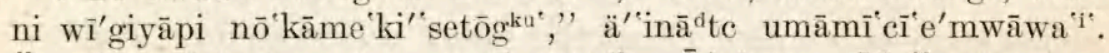

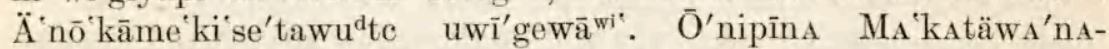
gwäws kabōtwe'megu ä'pemiwä'pu'säd $\mathrm{tc}^{\mathrm{i}^{\circ}}$.

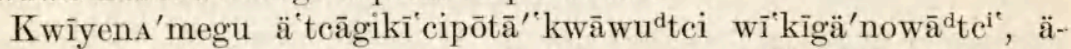
40 'pemipī'tiga'dci wī'tegōw ä'ketudtci nana'gutägki'. Me'to`säne'ni-

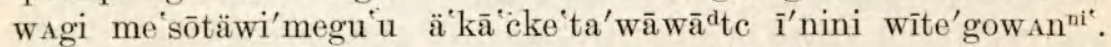

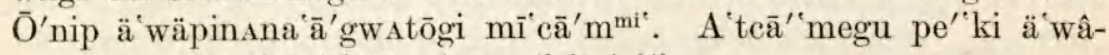
pats'mowa ${ }^{\mathrm{d}}$ tc $\bar{i}^{\prime}$ nigi käteminawe ${ }^{\prime 2}$ sitcigki".

1 An extremely difficult passage.

2 The tree grows near the Cedar River; something like the cottonwood. 
you shall say in future speeohes, and you will know the manitous whom you shall select. ${ }^{1}$ You are not to worship me alone here. There are manitous to whom you should also pray. So think earnestly of me," they were told.

After he had spoken they ceased seeing him where he had been sitting. They only saw the sacred pack. It was in a pile without anything else. "There it is," they said between themselves. Then, it is said, they wrapped it up with bark. ${ }^{2}$ Only the flute was not there; that alone was not there. Then it is said (the man) was told by his niece, "Well, my uncle, the flute is not supposed to be there. You are to make that which is to be a flute, you are to make it. You will know how you are to make it," he was told by his niece. "Oh, that is certainly so, my niece; you have reminded me. I am truly not very intelligent, my niece. You verily please me by reminding me. My niece, keep firmly in mind what he told us. Do not think, 'I guess I'm not a man.' Verily our grandfather thought of you, my niece; that is why he pitied you," Black-Rainbow said to his niece. "You will speak to me, my niece, when I make a mistake." "All right, my uncle. You are a man and I am a woman. My fellow-women are the ones for me to tell, and your fellow-men are the ones for you to tell," he was told by his niece. "I declare, my niece, that is exactly what you should do," he said.

Then they went home. They took the sacred pack along. The young man continued on the way in the rear, and the virgin was in the lead. Then, it is said, when they came close, he said to her, "Well, my niece, from here on proceed alone. The members of our gens are to hunt. We shall celebrate a gens festival," he said to her.

Then the maiden departed and told her story. She told their old man that they should hunt for game. The old man set the time for four days.

And Black-Rainbow, the one who held the sacred pack in his hands, remained standing far off in the same spot. And it is said that he was seen by no one.

And the woman, Deer-Horn, said to their ceremonial attendants, "Well, ceremonial attendants, put fresh earth in this wickiup." ${ }_{3}$ And their dwelling was strewn with fresh earth. Then it is said, Black-Rainbow suddenly started to walk.

Precisely when everything already was put in the kettles to be cooked so they might celebrate a gens festival, the owl entered and hooted in the space between the fires. All the people heard the owl. Then they began to lay the sacred pack in its proper place. The ones blessed looked at it intently. 


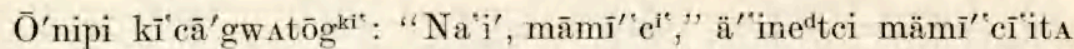

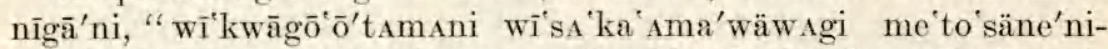

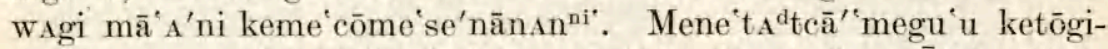

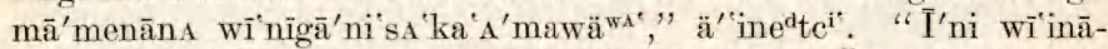

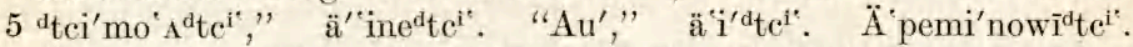

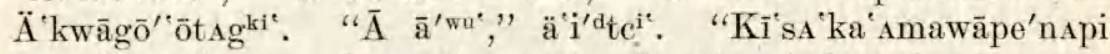
keme ${ }^{\prime} \bar{m} e^{\prime}$ 'senāns kätemi'nāgāts". Cewä'nspi ketōgimā'menāna

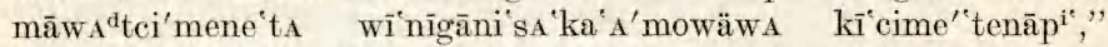
ä $\mathrm{i}^{\prime} \mathrm{d}$ tci kwägō' $\bar{o}^{\prime} \mathrm{otagkA}$.

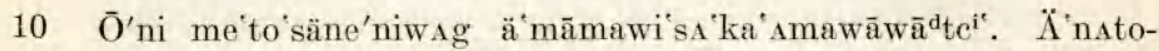
tama'wāwādtei pemāte"'siwen ${ }^{\text {ni". }}$ "Neme'cō'me'se, kenwä 'ci'-

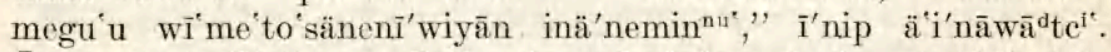

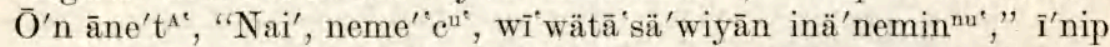

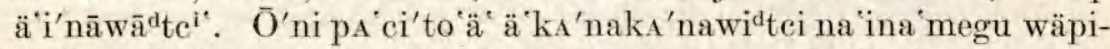

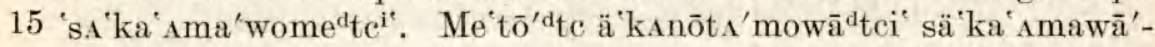

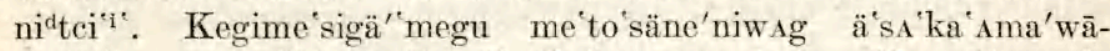

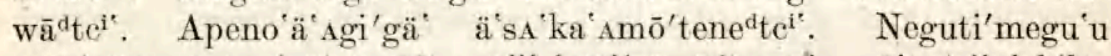

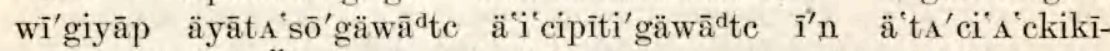

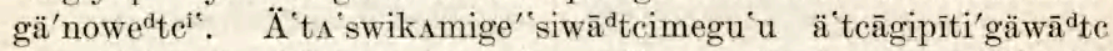

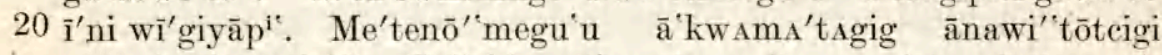

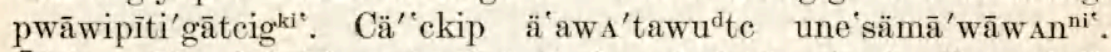

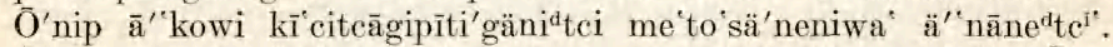

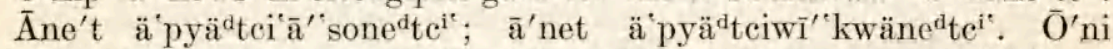
nā'kA'dtci myā cī'gwātcigki'; $\bar{o}^{\prime}$ ni pe'ki'megu kägyäpī'gwātcigki'.

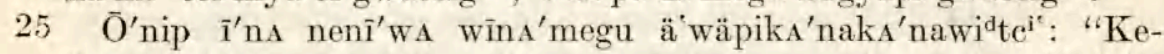
'kye'ki'nawā ${ }^{\mathrm{d}}$ tei ke'ten k ketemina'wigwäni ma'netōis". Mā' ${ }^{\prime \prime}{ }^{\prime}$ gi kenäwāpe'na pwāwimenwipemā'te'siwen ä'tōtcigki'. Ke'känemigwänidtcā'ma'netōwa mā's'gi wītcāgi'megu'umenwipemā'te'siwagki:. Mā' $A^{\prime} g$ ā'net ini'megu ä'katawinepowä'nemagkwe'; nā'kA

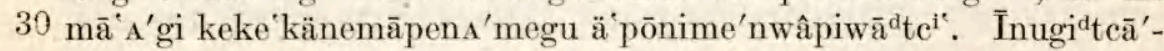

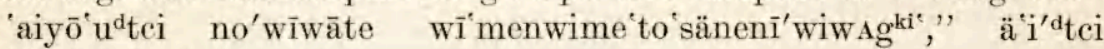
MA'katäwa'nagwäma'.

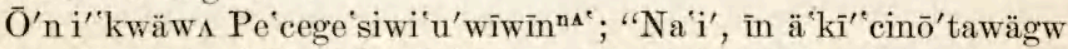

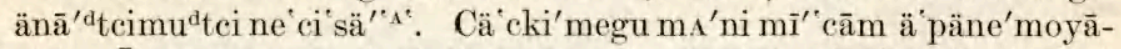

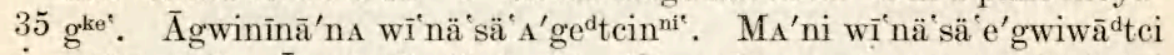

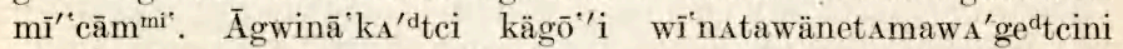

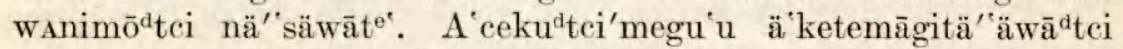

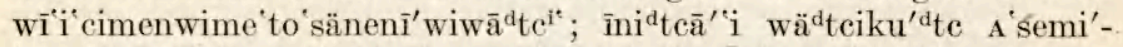

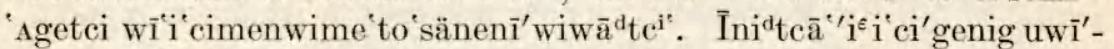

40 yawāwi kā'ta kwīnsta'wi cinawä'ī'yägägku". Cä'cki mA'ni mī'-

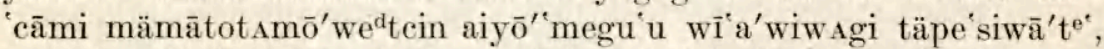
' $m \Lambda^{\prime}$ ni wä'dtcimenwime to sänenī'wiyāni', i citä' äwāte'. Ini'megu'u' $\operatorname{cä}^{\prime \prime} \operatorname{ck}^{\mathrm{i}^{*}, "}$ 
Then, it is said, after it was laid in its place, the one who was the head ceremonial attendant was told: "Well, ceremonial attendant, you are to cry out at the top of your voice that the people are to make an offering to this, our grandfather. Verily our chief will first make an offering to him," he was told. "You are to tell him that," he was told. "All right," he said. Then he started to go out. He cried

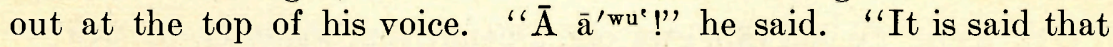
we shall make offerings to our grandfather who bestows blessings. But, it is said, our chief will especially first make an offering to him after it is unpacked," said the one who cried out at the top of his voice.

Then the people went to make offerings to him. They asked for life. "My grandfather, bless me that I may live long," it is said they said to him. And it is said that some said to him, "Bless me that I may be a warrior." And an old man spoke when the offerings began to be made (to the owl). It was just as if he was speaking for those who made the offerings. All the people made the offerings. And the little babies were made to give offerings. (First) those of one wickiup entered where the gens festival was first held. As many households as there were all entered that wickiup. Only the sick who were unable to move were those who did not enter. Their tobacco was merely fetched. And it is said that after all the people had entered in the rear (the rest) were fetched. Some were supported as they came; some were bundled as they came. Moreover, there were some who had bad eyesight; and some who were completely blind.

Then, it is said, that man himself began to make a speech. "By this sign the manitou must surely have blessed me. We see these (people) who do not enjoy good health. The manitou must have blessed me so that all these will become well. We know that some of these are nearly dead; and we know that these have ceased having good eyesight. Verily when they go out from here to-day, they will enjoy good health," said Black-Rainbow.

Then the woman Deer-Horn (said): "You have now heard what my uncle has related. We depend upon this sacred pack solely. We shall not heal them by ourselves. This sacred pack will heal them. Moreover, if they become well we do not desire anything from them. For (we help them) when they feel wretched so that they may thus live in health; that is why we help them, so that they thus live in health. Verily if that turns out so, do not try to trouble their body. Only when this sacred pack is worshiped they are to be here if they are satisfied, and if they feel, "this (sacred pack) is why I enjoy good health.' That is the only thing." 


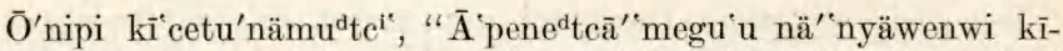

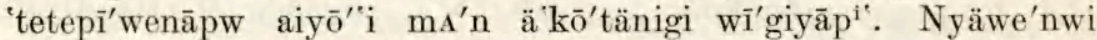

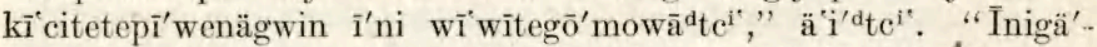

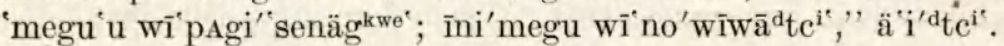

5 Ō'ni mene'ta kägyäpī'gwâtcig äpemitetepī'wene ${ }^{d}$ tci, ne'tawi'-

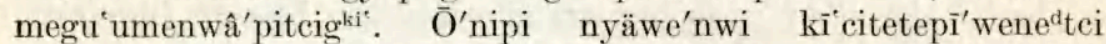

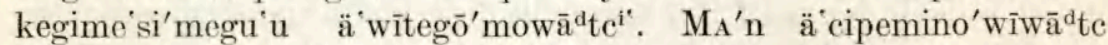

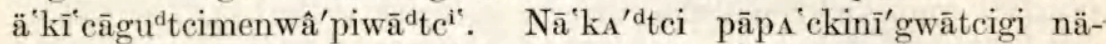

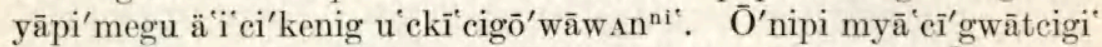

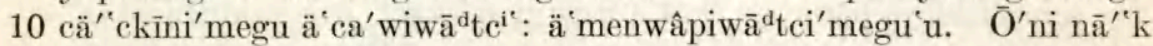
íniyägA wī'kwä'netcig a a'net ānawi tō ${ }^{\mathrm{d}}$ tcigi'megu'u ä'wäpitetepī'-

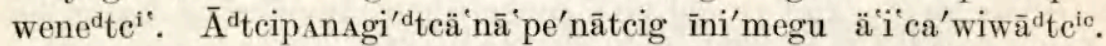

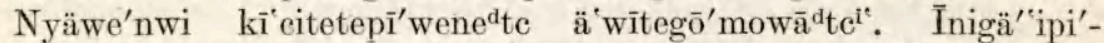

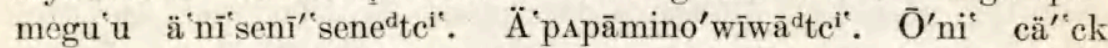

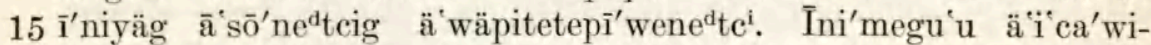

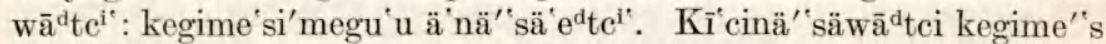

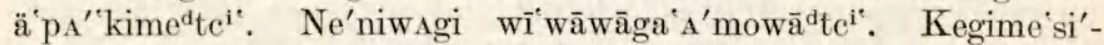

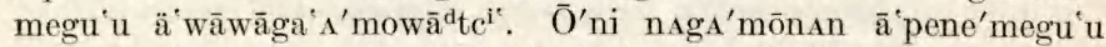

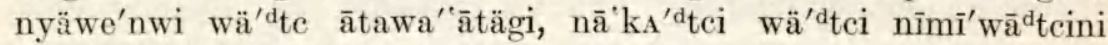
20 wāwāwāga $\mathrm{A}^{\prime} \mathrm{mowa}^{\mathrm{d}} \mathrm{tc}^{\mathrm{i}}$.

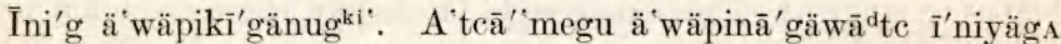

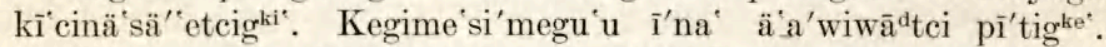
Ke'tena'megu'u ä'manetowäneta'mowădtci me'to säne'niwag $\bar{i}^{\prime}$ 'ni

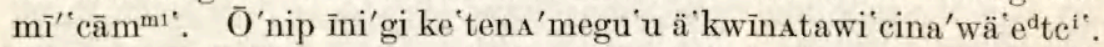

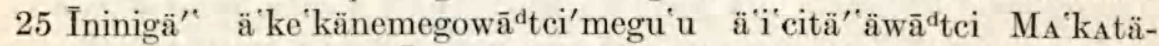

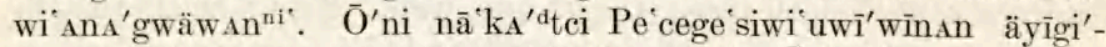
megu'u äke käneme'gowă ${ }^{d} t c$ äcitä ${ }^{\prime} a ̈ w \bar{a}^{d} t c^{i^{*}}$. Inigä' ip ä ${ }^{\prime} \Delta t A^{\prime} m a ̈-$ 'ed tci me'cku'pwä'ganan iñ̄' ${ }^{\mathrm{dki}}$ '.

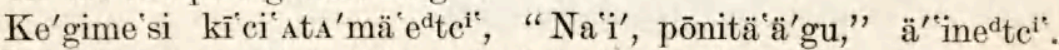

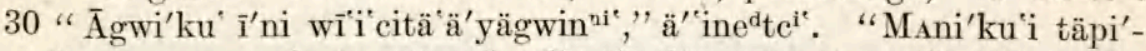

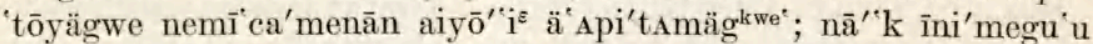

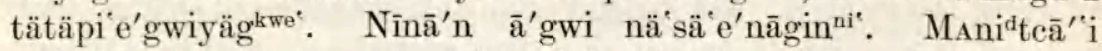
nä'sä 'e'gwiyägwe nanagutägi $\mathrm{mA}^{\prime} \mathrm{ni}^{\varepsilon}$ ä' tägi mī'cām ä 'pĩ'tcimane-

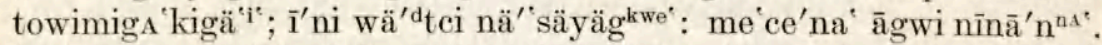

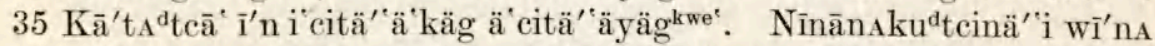
ma'netōw ä'kwinnatawinänemī'yame ${ }^{\mathrm{d}}$ tei wī' ${ }^{\mathrm{d}}$ tcimenwime 'to 'säne-

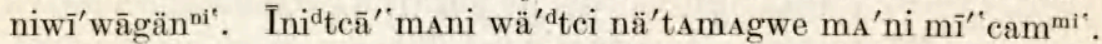
$\bar{A} g w i^{\varepsilon} A^{\prime} c^{\prime}$ megu u nätA'magwin ${ }^{n i^{*}}$. Wins'megu'u ke ${ }^{\prime}$ tcinäw aiyo ${ }^{\prime}{ }^{\prime}$

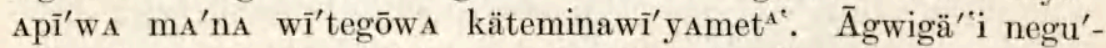
40 taiysg inänemīys'medtcini mānwaiyagi'megu. Netenäneme'gunāns

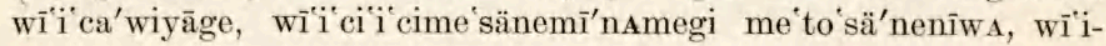


Then, it is said, when she finished her talk (she said), "You are to take them around in a circle four times, ${ }^{1}$ each alike, in the center of this wickiup here. After you have led them around in a circle four times then they are to hoot as owls," she said. "Then indeed you are to dismiss them; at that precise moment they are to go out," she said.

Then first those who were blind were taken around in a circle, and in a body, all those who could not see well. Then, it is said, after they were led around in a circle four times, all hooted like owls. At the time they started to go out they had most excellent eyesight. Moreover, eventually the eyes of those whose eyes were broken became as they had been. And, it is said, the same happened to those who had poor eyesight; they had good eyesight. And, moreover, those (spoken of) in the past who were carried in blankets who were unable to move began to be led around in a circle. The same happened to those who had various diseases. After they were led around in a circle four times they hooted like owls. Then, it is said, they were dismissed. They walked out. Then only those (mentioned) in the past who were supported began to be led around in a circle. The same happened to them: all were made well. After they were healed all were dismissed. The men were permitted to whoop. All whooped. And that is why the songs are repeated alike four times, and why they whoop when they dance.

Then, it is said, they began to hold a gens festival. Those who had been made well began to sing. All were there, inside (the wickiup). The people surely thought that the sacred pack (possessed) manitou (power). And, it is said, they were troubled in their hearts. And Black-Rainbow knew how they felt. And, moreover, DeerHorn also knew how they felt. Then, it is said, they were given the catlinite pipe to smoke.

After all had been made to smoke, they were told, "Come, cease to (be agitated in your) thoughts. You are not to feel thus," they were told. "Truly you will please our sacred pack here by occupying (the space) here $;^{2}$ and you will be gladdened by it. We did not make you well. Verily this made you well, the mystic power which is in this sacred pack in the space between the fires; that is why you are well; it was not we. Verily do not think as you have been thinking. For the manitou himself thought of us in a troubled manner so that we might live healthy lives. That is why we saw this sacred pack. We do not simply see it. He, this owl who took pity on us, is here in person. He did not think of one party of us (but) many. He planned what we were to do that the people might derive benefit from it, and that we might thus please them. To-day 


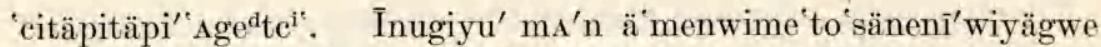

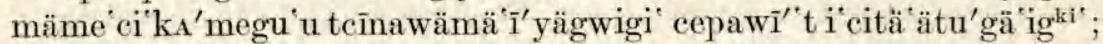

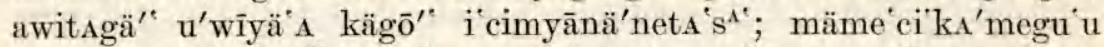

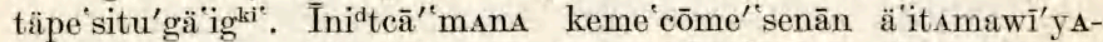

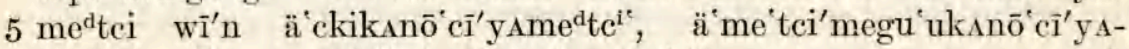

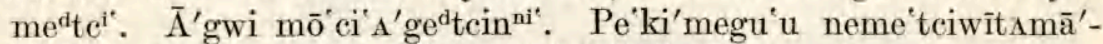

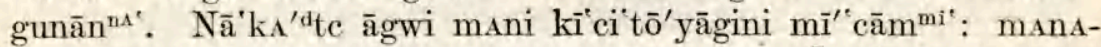

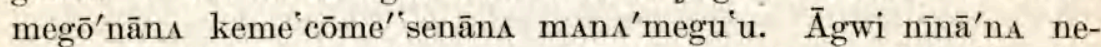

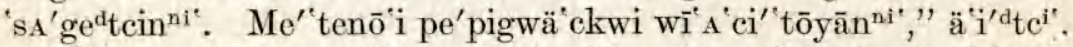

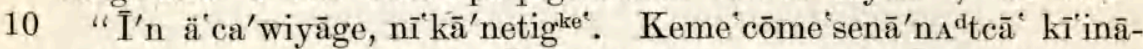

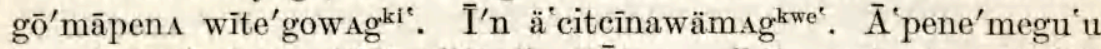

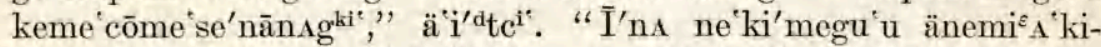

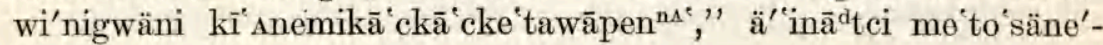
niwa ${ }^{{ }^{*}}$.

15 "Kā"cke'tawägwi'nidtcāi kĩsA'ka's'mawāpws wìte'gowagki',

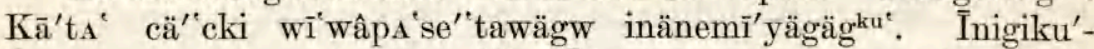

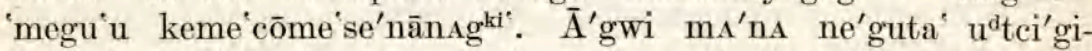

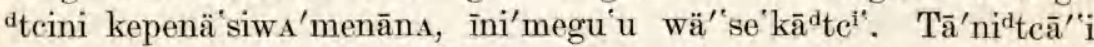

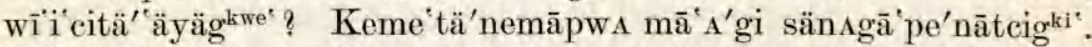

$20 \mathrm{Me}^{\prime}$ cena $^{\prime}$ megu'u nä'säwagki". Menwime to'sänenī'wiwa $\mathrm{g}^{\mathrm{ki} i^{\prime}}$. Mämä deigi'mā' ke'ckī'cegu'nānAni ketaiyō'pen ä'näwAgw ämenwime-

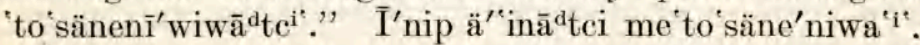

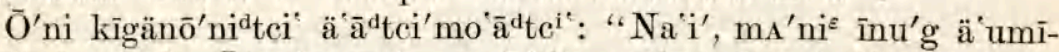

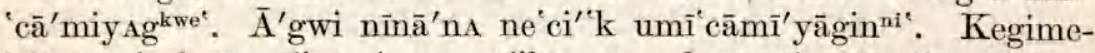

25 'si'megu u ketumī' cāmipwa nä' kīnwāwa ketepä'netāpwa'. 'Nī' kĩ-

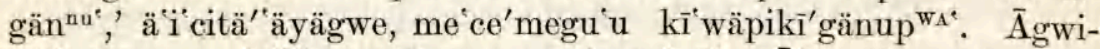

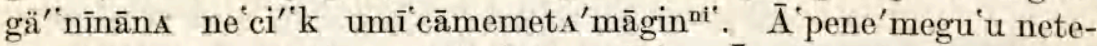

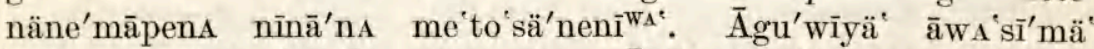

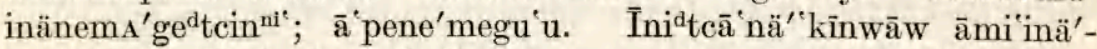

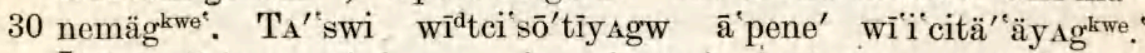
I'ni āmi cimenwa'wiyagw à pene'megu'u inä'nemagwe me'to'sä'neni $^{\mathrm{WA}^{*}}$,

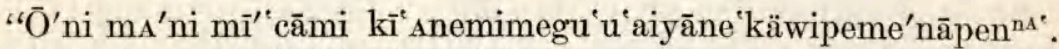

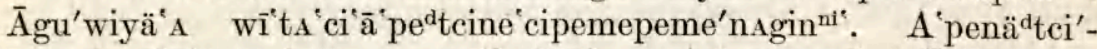

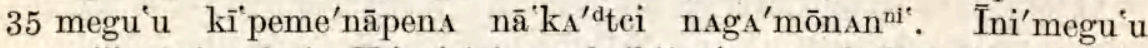

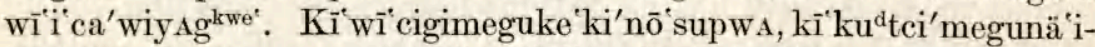
'íninitäpiwe'tōpena manA'k ä ${ }^{\prime}{ }^{\prime} \mathrm{kWA}^{\prime} \mathrm{kA}^{\prime} \operatorname{mig}^{\prime} \mathrm{k}^{\mathrm{i}}$. Mani'megu'u

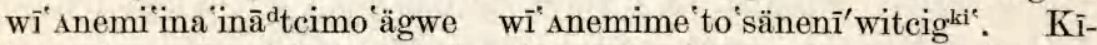

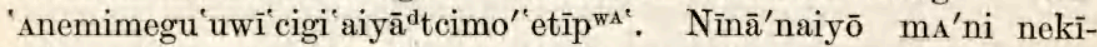

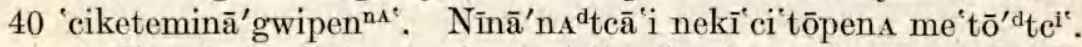

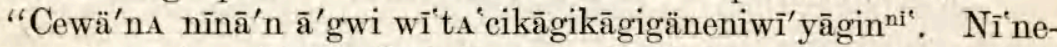

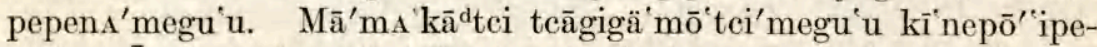

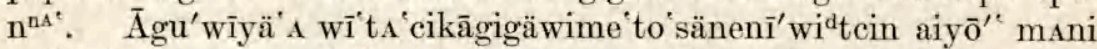

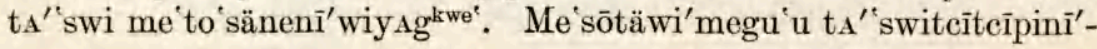


you who live in health here and your relatives probably surely think well of it; and no one would feel badly over it; surely they probably are pleased. This verily is what this grandfather of ours told us when he first spoke to us, when he actually spoke to us. We did not (merely) have a vision of him. He actually told us most openly. We did not make this sacred pack: it was this same grandfather of ours. We ourselves did not kill him. Only I was to make the flute," he said.

"That is what we did, my friends. We shall be related to owls as our grandfather. That is how we shall be related to them. (They will be) our grandfathers to all alike," he said. "As long as the world lasts we shall continue to hear them," he said to the people.

"Whenever you hear them you are to make an offering to the owls. Do not think of merely hearing them in jest. They are truly our grandfathers. This holy skin of ours did not come from simply any place, it came from the same place. What would you think? You have openly known these (people) to be afflicted with terrible diseases. And still they become well. They enjoy good health. Certainly we used our eyes when we saw them (regain) good health." That, it is said, is what he told the people.

And he related to those giving the gens festival: "Well, to-day we have a sacred pack. We (she and I) do not possess the sacred pack alone. You all possess the sacred pack and own it. If you think, 'I shall celebrate a gens festival,' you may celebrate a gens festival. We (she and I) do not own the sacred pack alone. We think of the people alike. We do not think of any one more (than another); (we think of you) alike. That is the way you should think of them. As many of us as are of the same gens are to think alike. In that we should contrive to be well, that is, if we think of the people alike.

"And we shall continue to take care of this pack one after another. No one is to take care of it there alone all the time. We shall (all) always take care of it and likewise the songs. That is what we shall do. You shall firmly remember them, for we are to take them to the end of the world. You are to continue to tell this to the future generations of the people. You shall continue to tell each other seriously. This has given us a blessing. It is the same as if we made it.

"But we shall not live here forever. We shall die. In fact we shall all die. No one of us who exist as mortals here, shall exist as a mortal forever. As many of us as blink have death, all of us who 
gwäysgwe kekege'sipe'na ne'poweni, kegime'simā'megu'u ta'swi-

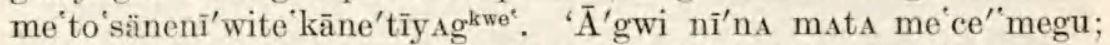

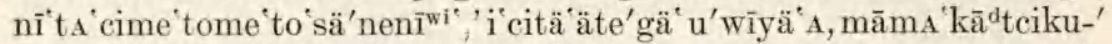

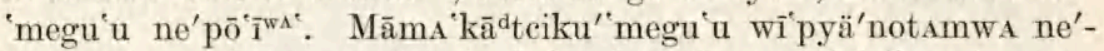

5 powen ${ }^{\mathrm{ni}}$. A'cemeguwì'nāni kekwaiyā 'ci'megu'ukī'ci'setā'gunānA wī'na ma'netōwa wĩ ita i'teyagkwe'.

"Wī'nA kī'cimamādtci” enAgw ä 'A 'sāmī'yätuge tca'kwā'kunAmō'nAgo `A keme'to 'säneniwī'wenenān ${ }^{\text {ni': }}$ I'niyätug ä'me'sōtäwi'dtcāi

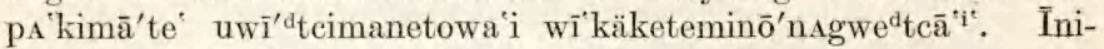

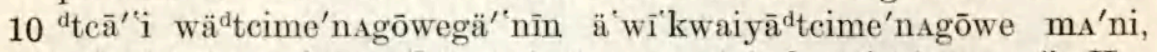
wī'wī'cigi'megu unene'käneta'mägwe ma'ni kemī'cā'menān ${ }^{n i}$. Ku-

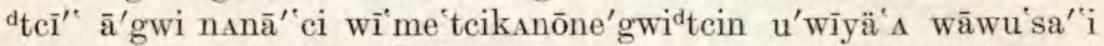
mō'tci tätäpi 'tō'te'. $\bar{A}^{\prime}$ gwi, 'o kīnsku'wī'na ketä'täpi i,' āgwi

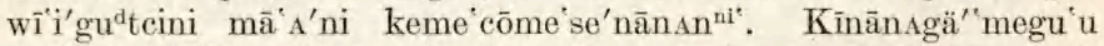

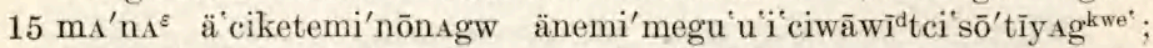

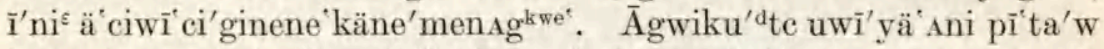

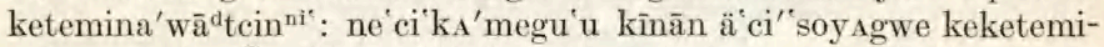
$n \bar{a}^{\prime}$ gunān ${ }^{\mathrm{n} \Lambda^{\prime}}$. Āgwi kägōo ${ }^{\prime \prime} i^{\prime}$ cinanā kaw inäneme'nAgwin ${ }^{n i^{*}}$; ä cimegumenwi'genig $\bar{i}^{\prime \prime} \mathrm{ni}^{\varepsilon}$ äneminäne'menagkwe'. Āgwinināna ne'ci' $\mathrm{k}$

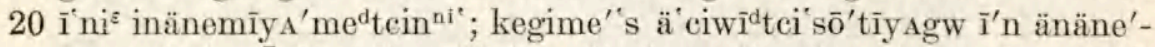

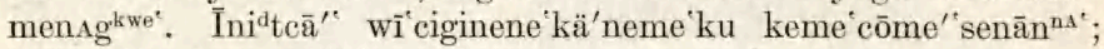
$\bar{I}^{\prime}$ ni wä'dte ine'nagōwe'.

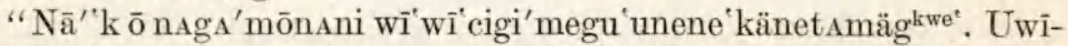

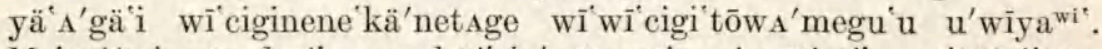

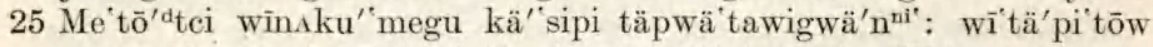

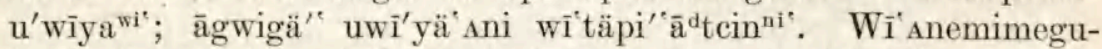

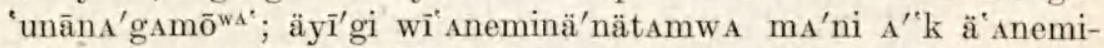
ku'kwäkāpatā'ninigki. Menō'kA'minig ä'Anemi 'A'ckipagāme'ki'se-

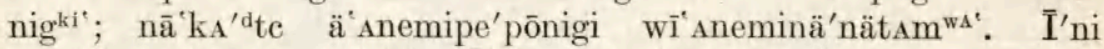
30 wï ciginene känetamu'gku'. I' I'ni wä'dte ine'nagōwee.

"Nā'ka dci mani'megu'u wĩ'wätā'säwi'e'gwiyägkwe". Nā̄kadtc à'gwi wī'Anemikyātamā'tīyägkwe'. Mämä 'tcigi'megu'u kĩ̀Anemipe-

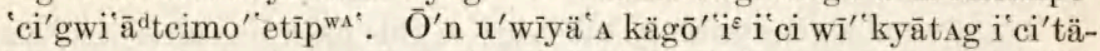

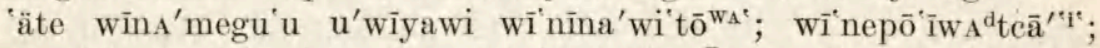

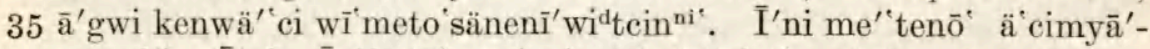

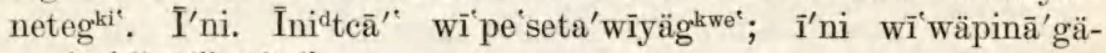
yagkwe'," ä' in $\bar{a}^{\mathrm{d}} \mathrm{tc}^{\mathrm{i} \text {. }}$.

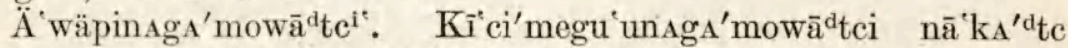

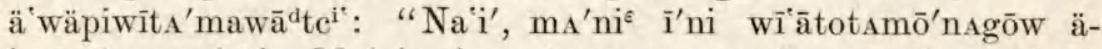
40 'naga'moyagkwe:. MA'ni ${ }^{\varepsilon}$ ä naga'moyagwe ma'netōwa keneno ${ }^{\prime} \bar{a}^{\prime}$ gunān ${ }^{\mathrm{nA}}$. Ke tenagä' megu'u keneno 'tā'gunāna ma'netō ${ }^{\mathrm{wA}}$ '. $\overline{\mathrm{A}}^{\prime}$ gwi

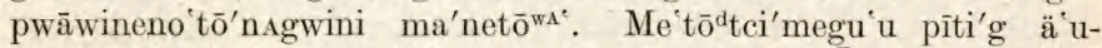

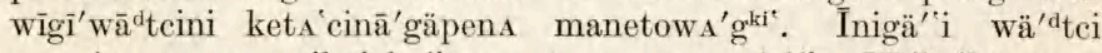

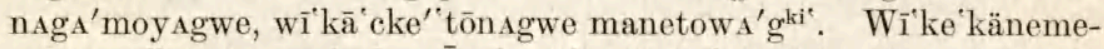

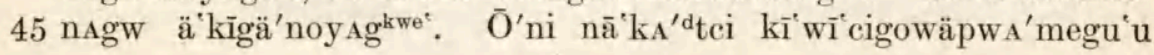


call each other mortals. If any one thinks, 'No, not I; I shall always exist as a mortal,' he surely dies. He surely comes to death. For he, the manitou, has fixed that which will happen to each one of us.

"He who made us move probably shortened our life too much. So he probably permitted all his fellow-manitous to bless us. That is why I tell you this, and already have told you, that you think seriously of this our sacred pack. Yet it will never actually speak to any one even if he 'pleases it. He will not be told by this grandfather of ours, 'you please me.' It is us and future generations of all the members of our gens whom he thus blesses; that is how seriously he thinks of us. For he does not bless any one else: he blesses our gens alone. He does not think of us in any way that is evil; it is in a good way that he will continue to think of us. It is not us alone whom he thinks of; he thinks of all of us who are of the same gens. So think seriously of our grandfather; that is why I tell you.

"And you must think seriously of the songs. And if any one thinks seriously of them, he will strengthen his own body. It is the same regarding whoever believes in me: he will make himself happy; he will not make any (other person) happy. He will continue to sing; also he will continue to see this earth as the seasons shall change. In the spring it will continue to be green; and he will continue to see the future winter. So think seriously over (this). That is why I tell you.

"Moreover, this will make you warriors. Moreover, you are not to hide it from each other. You will surely tell each other in an upright fashion. And if any one thinks of keeping it secret in any way he will weaken his own body; he will die; he will not live long. That is the only evil in it. That is all. Now you are to listen to me; now we are to begin to sing," he said to them.

Then they began singing. After they had sung he likewise began telling them: "Well, now I shall tell you about this which we sing. As we sing the manitou hears us. The manitou really hears us. The manitou will not fail to hear us. It is just as if we were singing within the manitous' dwellings. 'That is why we sing, namely, so the manitous will hear us. They will know when we celebrate a gens 


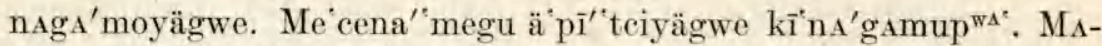
ni wä'de $\overline{1}^{\prime} n$ ine'nagōwe:

"A $\bar{A}^{\prime}$ gwi mî̀ cădtcināgä'yagwin ni". Me tōódtei kemai'yōpen änA-

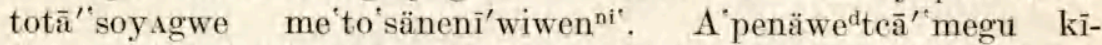

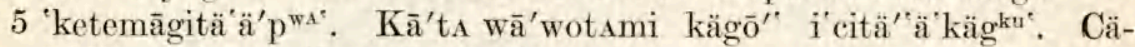
'cki'megu'u ma'kwā'dtei kĩ i'ci'tä äpwa pemiwäpināgä'yägwin ni". MA'nA nā' $k$ änwäwä' igāta pe'ki'megu wīwīeigipA'gAmäw $A^{\prime}-$

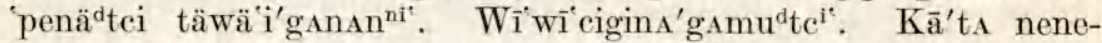

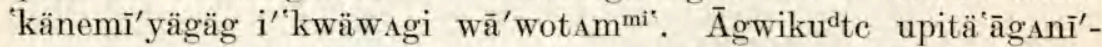

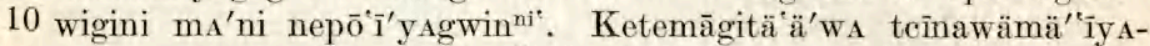
gwa pänāpame'nagwin ni'. Inid ${ }^{d} t c \bar{a}^{\prime}$ wädtcime'nagōwe, ' $m{ }^{d} k w \bar{a}^{\prime}-$

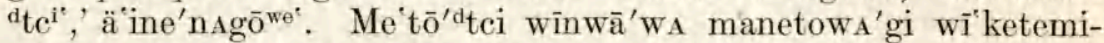

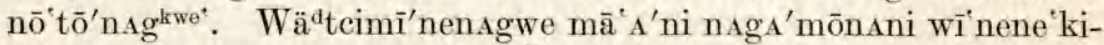
nawä'magwe manetowA'gki . Āgwigä'ci wĩ upina'wämagkwe'; wī-

15 'ketemāgäne'menagwe; wĩ'keteminō'nagwe ${ }^{d} t c a \bar{a}^{*} \bar{i}^{\prime} n i$ wädtci'mä Ani

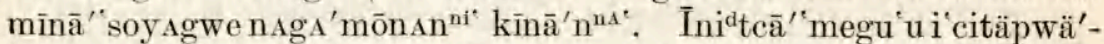
'tawigku"; ä'inenagōwe'megu'u i' cawigku'.

"A'penädtci'megu kî'wî̀cigināgäpws'megu'u. Nā'kA'dtci" cî̀cī'-

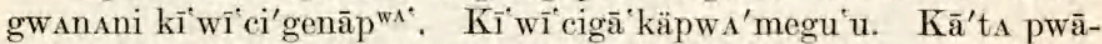

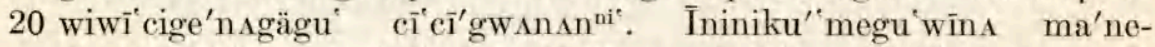
tōwa teā'gi pemipe se'tagin ä pī'twäwä'se'nigwäni' cī'cī'gwanan ${ }^{\text {ni }}$, Awita'megu'u u'wīyä'A wāwanänemenä' A kä cawend'mugwänA

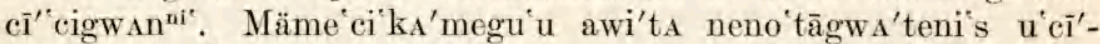
'cigwan ${ }^{n i}$. Innid tcā' wädtcime'nagōwe, 'wï'cige'namugu' cī'cī'gwA-

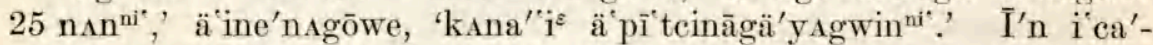
wiyägwe kītäpi i'pwa, nā'kA'dtci pwāwi'megu unegu'ta inā'piyägkwe', aiyänīwe'megu'u tanā'piyägwe, nā' ${ }^{\prime} A^{\prime d}$ tci pwāwi'megu'umāta' piyägw ä pî̀tcikīgä'noyagwe, î́n āmi ca'wiyägkwes. NAtawä-

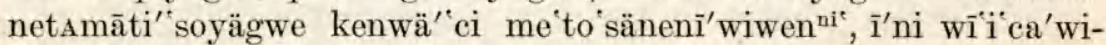
30 yägkwe?

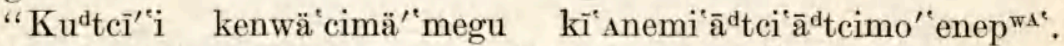

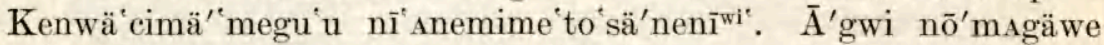

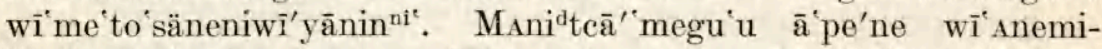
“ina inādtcimo e'nagōwe ne'ki'megu'u wī'Anemime to säneniwī'wā-

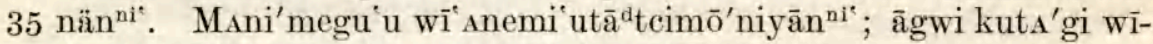

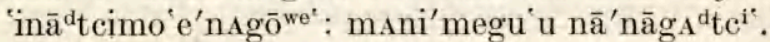

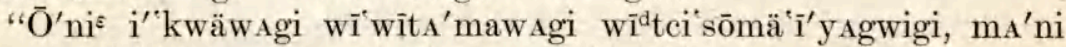

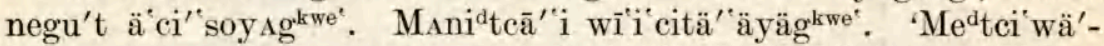

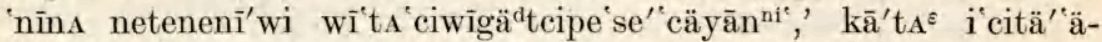

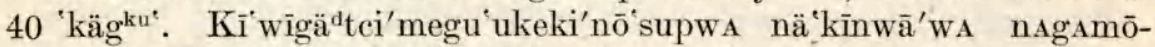

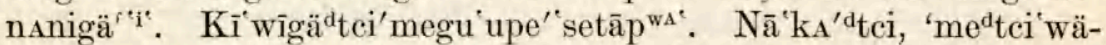

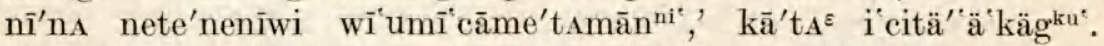
Kīnwāwaku'nä'mani'megu'u ä inäne'menāgwe ma'na keme cōme'-

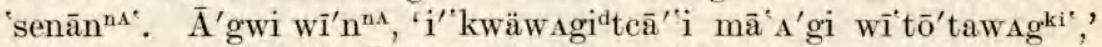
$45 \bar{a}^{\prime} g w$ i citä' ä ${ }^{d} \operatorname{cin}^{n i}$. Ini'megu'u änene känemenāgwe nä'kīnwāw 
festival. And you are to sing loudly when you sing. You shall sing as loud as you can. This is why I tell you.

"We are not singing sportive songs. It is as if we are weeping, asking for life. You are to think sadly all the time. Do not think of anything unnecessarily during that time. You are only to think quietly when you start singing. And as for this fellow, the drummer, he is to beat the drum vigorously. He is to sing loudly. Do not think of women unnecessarily (during this time). For there is no happy feeling when we die. Our relative feels sadly who sees us no more. That is why I said 'quiet' when I told you. It is just as if they, the manitous, will bless us for it. That we should be mindful of the manitous is why they gave us these songs. We shall not make them happy; that they have compassion on us; that they bless us is why we are given these songs. Therefore you shall believe me; do as I tell you.

"You are always to sing loudly. And you are to hold the gourds (rattles) firmly in your hands. You will rattle them loudly. Do not fail to hold the gourds firmly in your hands. The manitou himself listens to all of them and hears how the gourds sound. He would not fail to know any one who held the gourd loosely. Probably his gourd would not be heard. That is why I tell you, 'hold the gourds firmly in your hands while we sing.' If you do that you will please me, and if you do not look around aimlessly, if you look at one spot, and if you do not move your seat while we are celebrating a gens festival, if you contrive to do that. If you desire long life for yourselves, that is what you are to do.

"Of course for a long time I shall continue to instruct you. I shall continue to live for a long time. I shall not live for a little while. I shall continue to tell you this all alike as long as I shall continue to live. I shall continue to tell this; I shall not tell you another way: this will be always the one way.

"Now I will instruct the women of our gens, this one gens of ours. This truly is how you will think. Do not think, 'I am not a man, so that I should listen carefully.' You are to remember the songs carefully. You are to listen carefully. And do not think, 'if I were actually a man I would have (share in) the sacred pack.' This our grandfather thinks of you exactly as he thinks of us. He does not think, 'I shall not care for these women.' In whatever way he 


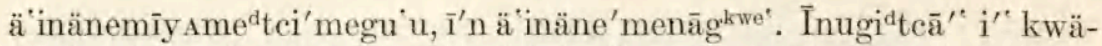

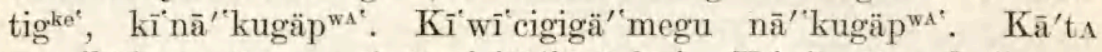

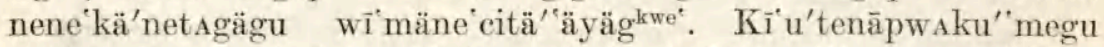

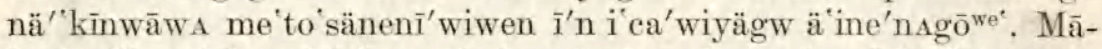

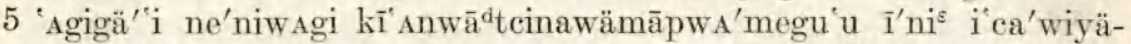

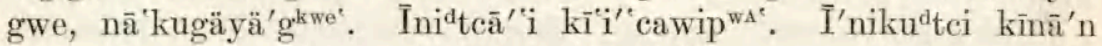

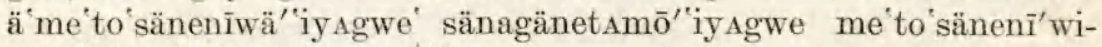
wen $^{\text {ni" }}, " \ddot{a}^{\prime}$ "inādte i' kwäwa'".

"Inidteā'i wädtcime'nagōwe, 'kā'ta mäne'citä"āgani nene'kä'-

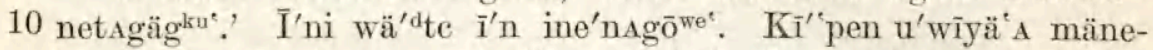
'ci'tä äte, wīnA'megu me tōo'dci wī'ā'tcine'kamā'ti'sōw upemāte'-

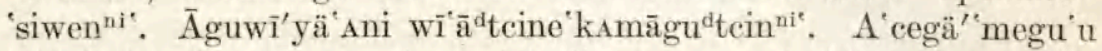
kĩi'citä'äna'wä'sipwa wĩ'mäne citä'äyägwe, me'tō'dtc ä'ss'nagA'ki

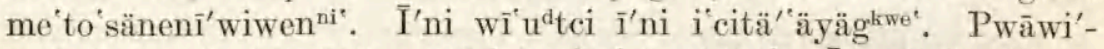

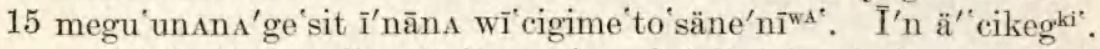

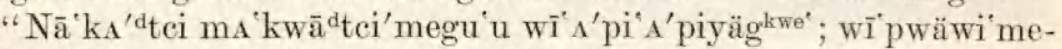

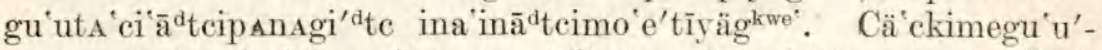

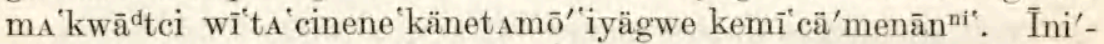

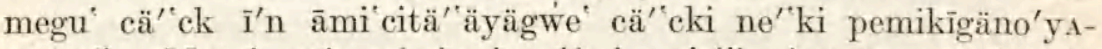

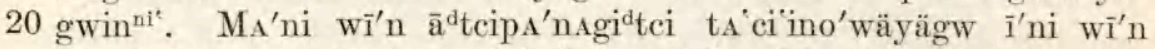

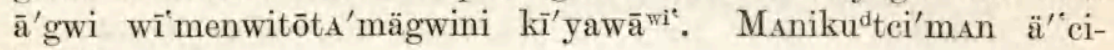
$\mathrm{kegki}^{\mathrm{ki}}$.

"Pemāte" siweni nīnaiyō'mani nīns'megu kä'sipi netıgāwātA'māti's ${ }^{u^{*}}$. Ini'megu ä'ca'wiyagkwes. Mō'tci mānä'tōyagwe nä'tA-

$25 \mathrm{magw}$ aiyāgwatä'gki', awi'tA täpänemo' 'kAgo'A wīpōni'Atāpe'nAmagwe wädtcinowa'tōig ä'stā'pe'namegki". I'ni āmi i ca'wiyagkwe:

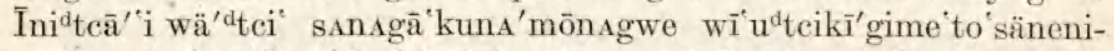

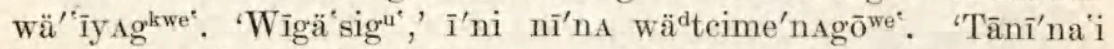
kenwä cimä"’ Aneminäwo'tīwāte wīitci sō'magigki', ä inäneme'nA-

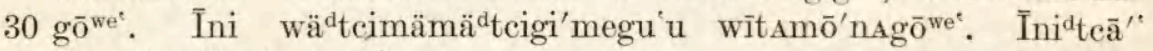

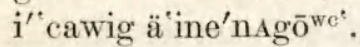

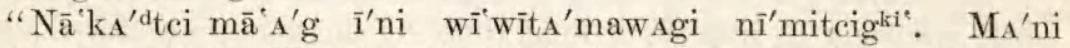

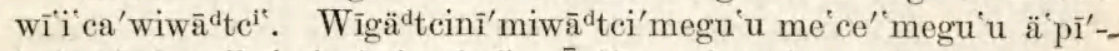

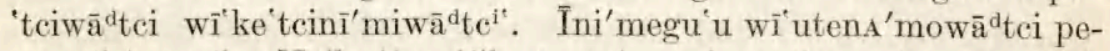

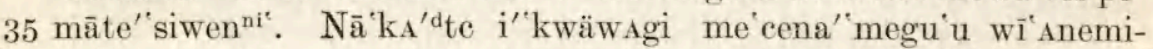
nā'kunā'ku'gäwagi me'cemegō'na' ä'citä' àtcigki'. 'Nīnā'ku'we',

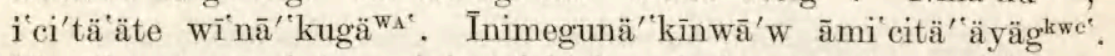
Nene känetagägo 'A'megu'u cä'cki keme to säneniwī'wenwāwi'. A-

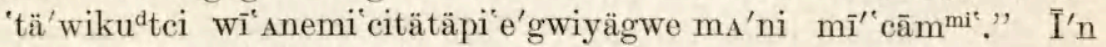
40 ä inā'tsteipi me to'säne'niwa ${ }^{\text {“'. }}$.

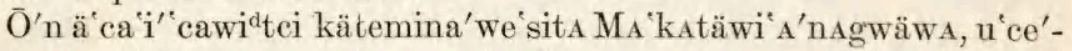
mī'Ani Pécege'siwuwī'wīnan ${ }^{\mathrm{ni}}$. Negute'nwi mā'ne äme"ce-

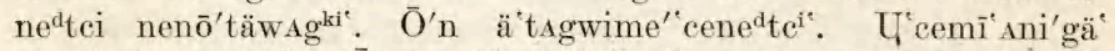

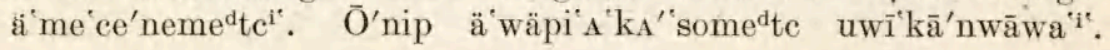


thinks of us he thinks of you. Verily, women, to-day you are to hum (the songs). You are to hum loudly. Do not think of being bashful. You will derive life from it if you do what I tell. You will make these men willing if you do that, that is, if you hum. Verily you are to do that. For life is what we who are mortals think hard," he said to the women.

"That is why I tell you, 'do not think bashful thoughts.' That is why I tell you. If, however, any one is bashful, it will be as if she shortens her own life. It is not shortened by any one (else). It will just come into your hearts to be bashful, because life is as if difficult. That is why you will think thus. The one who is not nervous has a strong life. That is how it is.

"And you are to remain seated quietly; you are not to tell all sorts of stories to each other. You are to only think quietly of our sacred pack there. That is all ycu are to think of during our gens festival. If now you tell all sorts of things there you will not do good to your body. This is how it is.

"I desire life for myself alone. That indeed is what we all do. Even if we had much of it and saw it, if it were in a large pile, we would not be satisfied in our minds so that we. would cease taking it if it were easy to take. That is what we would do. That is why he made it difficult for us to live perfectly strong. That is why I tell you, 'be careful.'. 'Would that the fellow members of my gens might continue to see each other for a long time,' is what I think of you. That is why I tell you truthfully. So do that which I say to you.

"And now I shall instruct those who dance. This is what they are to do. They are to dance carefully (but) violently while they dance. They will obtain life from that. And any women who so desire shall continue to hum (the songs while dancing). If she thinks, 'I shall hum,' let her hum. You shall think just the same. You shall think solcly of your life. For there is a time when this sacred pack will make you happy always." That is, it is said, what he told the people.

Now as to what happened to the one that was blessed, BlackRainbow, and his niece Deer-Horn. Once many of the Indians were captured. And he was captured with them. His niece, too, was captured. And it is said that their friends began to be burned. All 


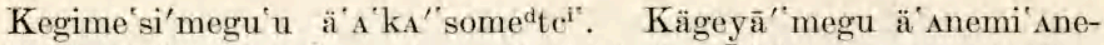

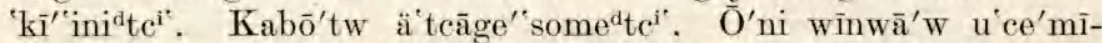

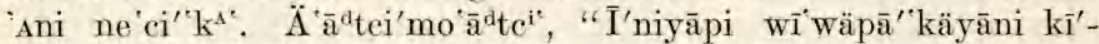

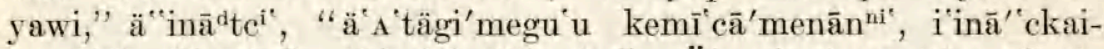

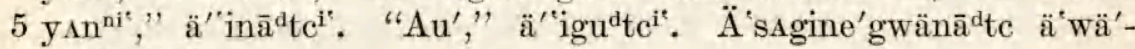
"pā'kädtcie

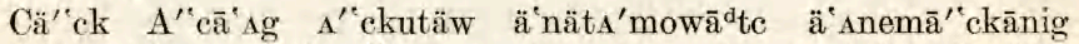

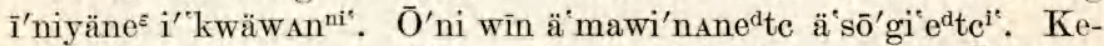

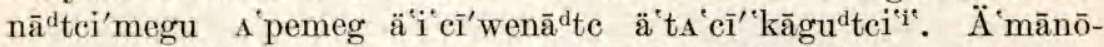

10 'kawudtcigä' $i$ cewä'n äpwāwi'megu'ukA'cki'sō'gi ${ }^{d}{ }^{d} c^{i}{ }^{i}$. A'peme-

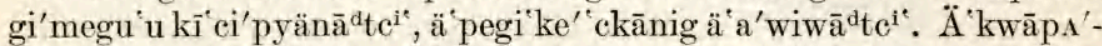

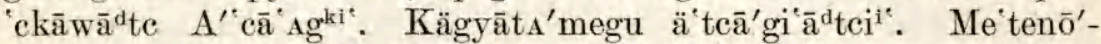

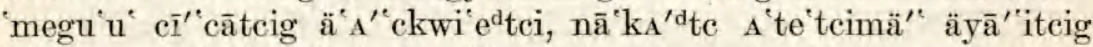

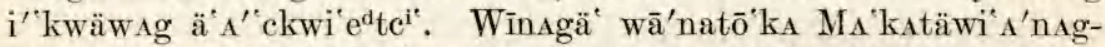

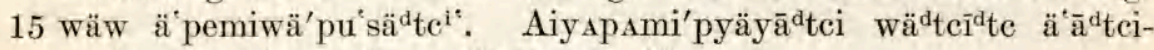
$\mathrm{mu}^{\mathrm{d}}$ tc ä tōta'wome ${ }^{\mathrm{d}}$ te uwī'kā'nwāwa ${ }^{\mathrm{e}^{\mathrm{i}}}$.

$\bar{O}^{\prime}$ nip änstwäwä $i^{\prime}$ gawādtc ${ }^{\mathrm{i}}$. Māne'megu'u ä'pyāwādte $A^{\prime}$ cā'Agki'. Kegime'si'megu'u ä'me'cened ${ }^{\mathrm{d}} \mathrm{e}^{\mathrm{i}}{ }^{\mathrm{c}}$. Ini'megu'u ä'tōta'wāwă $\bar{a}^{\mathrm{d}} \mathrm{e}^{\mathrm{i}^{*}}$. Wīnwā'wapīn 'ä'mai'yōwā ${ }^{\mathrm{d}} \mathrm{tc}^{\mathrm{i}^{*}}$. Kīgä'nawagi kegime'si'20 megu'u ä'mai'yōwā ${ }^{\mathrm{d}} \mathrm{cc}^{\mathrm{i}}$.

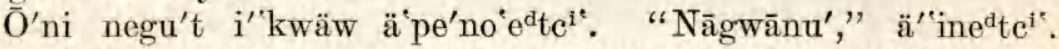

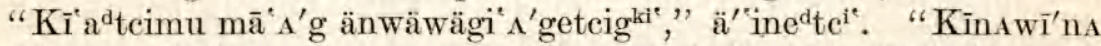

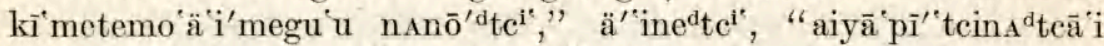

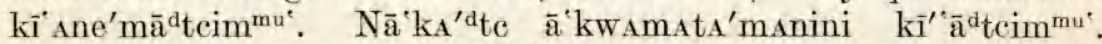

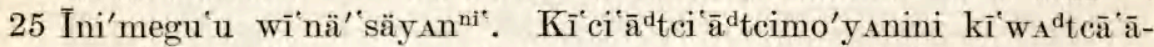

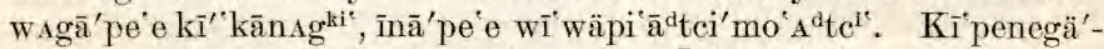

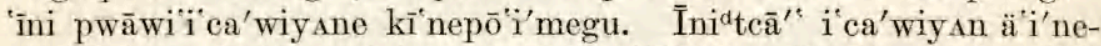

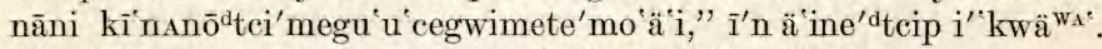

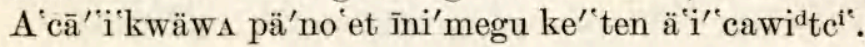

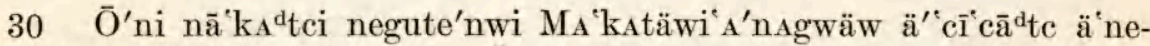

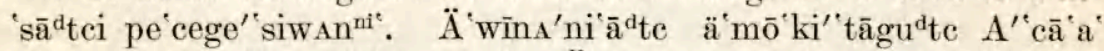

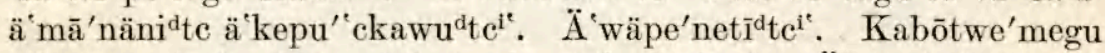

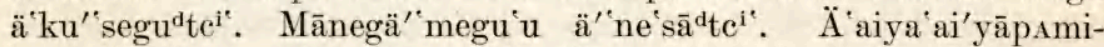

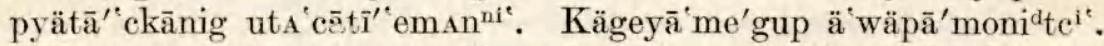

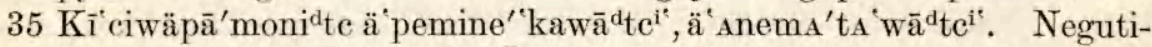

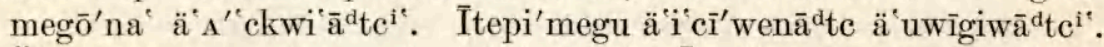

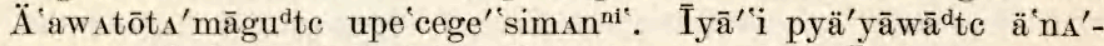

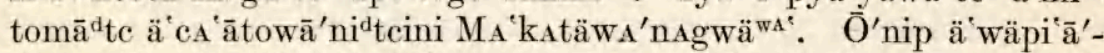

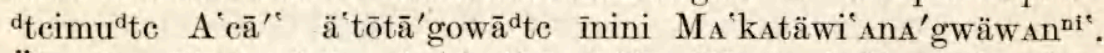

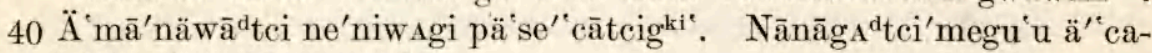
wide ä ${ }^{\mathrm{d}} \overline{\mathrm{a}}^{\mathrm{d}} \mathrm{tci} \mathrm{i}^{\prime} \mathrm{megu}^{\mathrm{d}} \mathrm{tc}^{\mathrm{i}}$.

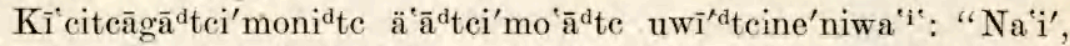

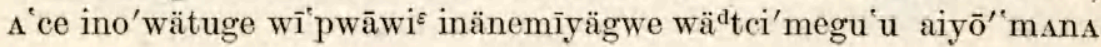


were burned. After a little while there were but few left. Soon all were burned. Then he and his niece were the only ones (left). Then he spoke to her, "Eventually I shall throw your body," he said to her, "you will fall where our sacred pack is," he said to her. "All right," he was told. He seized her by the arm and threw her.

The Sioux saw only fire going out of that woman. And they went to attack him and he was bound. Slowly he led those toward the sky by whom he was tied there. Although he was attacked by many yet they could not tie him. After he had brought them up in the sky, the (spot) where they were, broke to pieces. The Sioux scattered downward. He killed nearly all. Only the hunters were saved, and the women who were gone far off were saved. He himself, BlackRainbow, unconcernedly started to walk off. He arrived back whence he came and related how their friends had been treated.

Then, it is said, he made (the Sioux) come by beating his drum. Many Sioux came. All were captured. They treated them in exactly the same manner (as they had been treated). It is said that they themselves (the Sioux) wept. All the prisoners of war wept.

And one woman was sent home. "Depart," she was told. "Tell (your people) of these (prisoners) whom we made cry," she was told. "You will live to be an old woman," she was told, "you will continue to tell this story often during that time. And if you become sick, you are to tell the story. Straightway you will become well. After you tell the story you will cook for your friends, and you will then begin to tell them the story. If, however, you do not do this, you will indeed die. If you do as I tell you you will live to be a very, very old woman," is what the woman was told, it is said. The Sioux woman who was sent home did precisely that.

Then again at one time Black-Rainbow went hunting and killed a deer. As he was flaying it, many Sioux rushed on him and surrounded him. He began to fight them. Soon he was feared. He killed many. His arrows always flew back to him. Finally (the Sioux) began to flee. After they started to flee, he went in pursuit of them, striking them down in his course. He spared just one. He led him toward where (Black-Rainbow's people) lived. He made him carry his deer. When they arrived there, Black-Rainbow called for one who spoke Sioux. Then, it is said, the Sioux began telling how they were treated by Black-Rainbow. There were many men listening. The story of exactly what he had done was told.

After (the Sioux) had told the entire story, he himself related to his fellow men: "Well, that you may not think I am merely talking 
pyänA'gi, wīnnA wädtci $\bar{a}^{\prime d}$ tcimude ätōótawagi wī'nA, wä'dte $\bar{a}^{\prime}$ to-

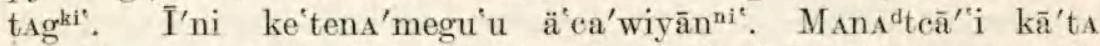

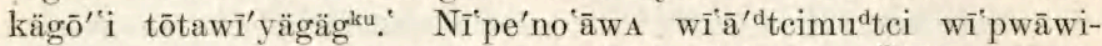

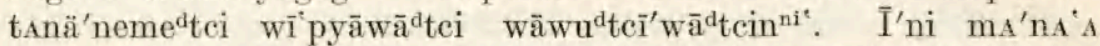

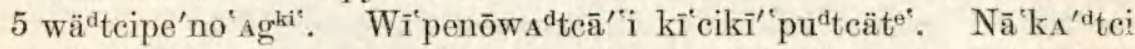

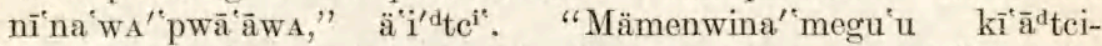

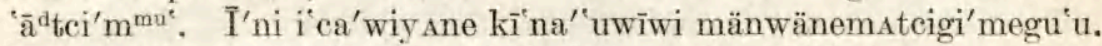
KïAnemi'uwī'wi'. Cewä'na kî'ku'ci'megu'u. Mō'tci'megu nä'wo-

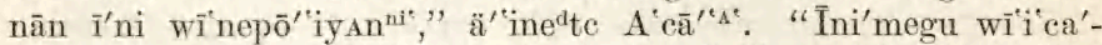

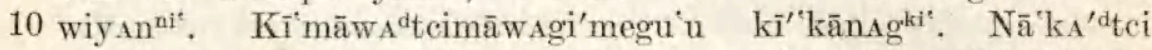

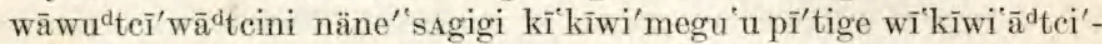

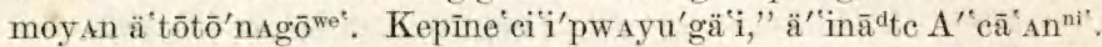

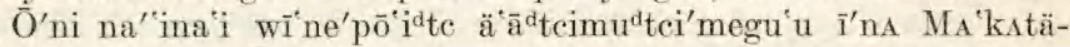
wi $A^{\prime} n$ ggwäwA'. Āgwigä'ipi wĩ'ā'kwA'matag ä'menwimegu ume-

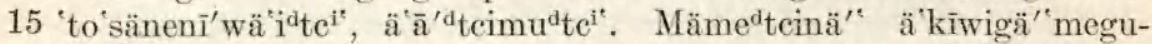

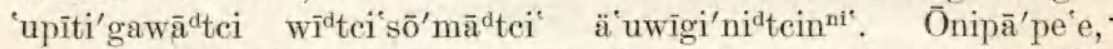
"Manīnina i wĩnagane'nagōwe, īna"megu'u wĩpe'noyānn"," ä i-

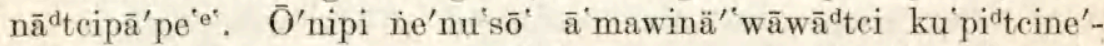
nu'sō'i'. I'nipi wīna MA'katäwi ${ }^{\prime}{ }^{\prime}$ 'nagwāwa māwa ${ }^{d}$ tcā'kowi'megu'u

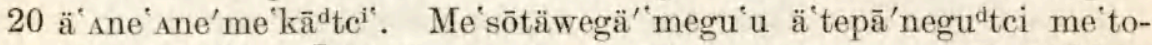
'säne'niwa ${ }^{\prime i}$. O'́nipi māne'megu ä Anemiwītä'megudtei u'ckina-

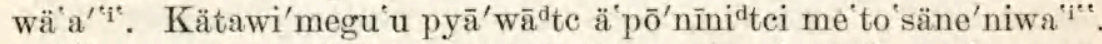

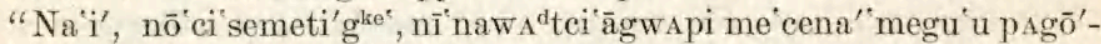

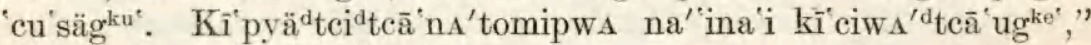

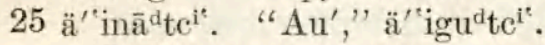

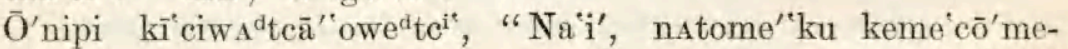

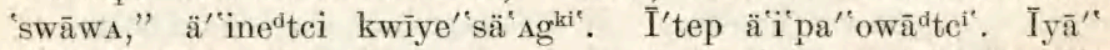

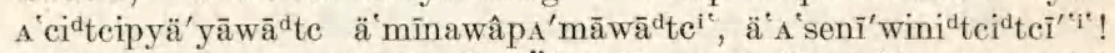

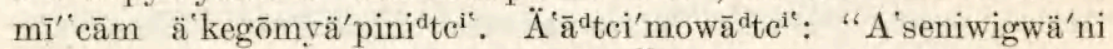

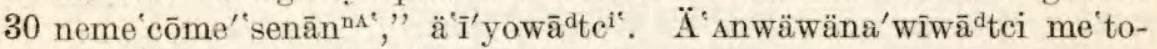
'säne'niwag ä'wī'ckwä'wägA'ki mä'yōtcigki.

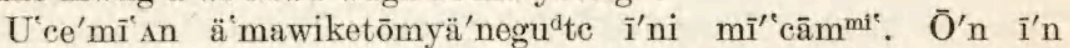

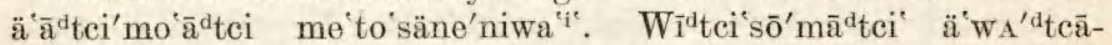

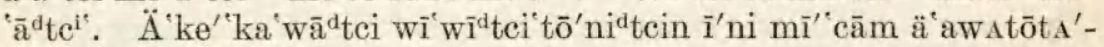

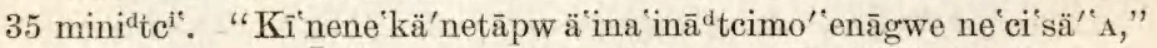
ä"inādte ${ }^{\mathrm{i}}$. "Ini'megu u i'cawi' kägo" ä ina inādtcimo'enāgwe

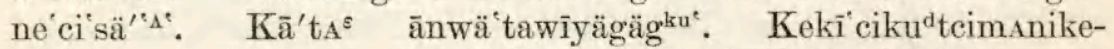

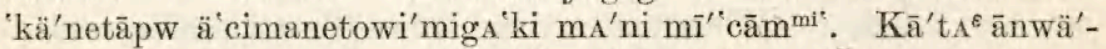

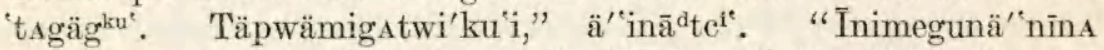

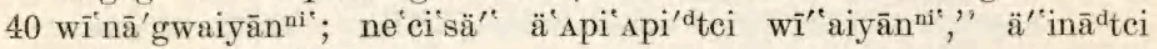

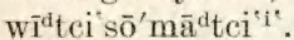

Ä'ānwigä'megukena 's'mawudtc änāgwādtci'megu'u. Ō'nip ittep

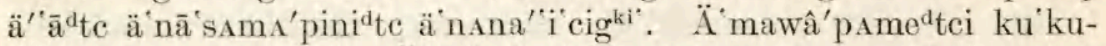

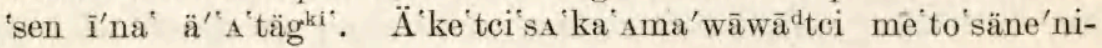


is why I brought this man here, and why he tells the story of how I treated him, and why I let him tell it. I surely did that. Do not do anything to this man. I shall send him home to tell the story so that they (the slain) shall not be expected to come back from where they came. That is why I send this man home. Verily he is to go home after his belly is filled. And I shall send food with him," he said. "You will of ten tell the story. If you do that you will be able to marry those you love. You will continue to marry. But you shall fear me. If I even see you, you will then die," the Sioux was told. "That is what you are to do. You will call your friends together and tell them. And you are to go around entering (the tents) from which those whom I killed came, telling how I treated you (pl.). You (pl.) attacked me first," he said to the Sioux.

Then Black-Rainbow told when he would die. He said that he would not be sick, as he had lived a good life. And he went around entering the dwellings of the fellow members of his gens for the last time. Then he would say to them, "This is the time when I shall leave you, when I shall go." Then, it is said, they went to see a herd of buffaloes. And, it is said, Black-Rainbow was walking in (their) rear. He was loved by all the people. And, it is said, he was accompanied by many young men. When the others had nearly come, the people camped. "Now, my grandchildren, I shall stop to rest here, and you are to go on. You will come to summon me when the cooking is done," he said to them. "All right," he was told.

Then, it is said, when the cooking was done, some small boys were told, "Well, summon your grandfather." They ran thither. When they came near and examined him, lo! he had turned to stone, sitting down with the sacred pack on his back. They reported: "Our grandfather must have turned to stone," thus they said among themselves. The people made a great stir and noise by crying and weeping.

His niece went and took the sacred pack from off his back. Then she instructed the people. She cooked for the fellow members of her gens. She named the person who was to live with the sacred pack when he took it away. "You are to think of what my uncle has told you from time to time," she said to them. "You should do exactly as my uncle has instructed you from time to time. Do not disbelieve him. You have already thoroughly learned that this sacred pack has the power of a manitou. Do not disbelieve it. Verily it is true," she said to them. "Now I shall depart; I shall go where my uncle is sitting," she said to the fellow members of her gens.

She disregarded their forbiddance and departed. Then, it is said, she went there and lay down in front of where (her uncle) was. When they went to see her, a granite stone was there. The people made $147567^{\circ}-21-5$ 


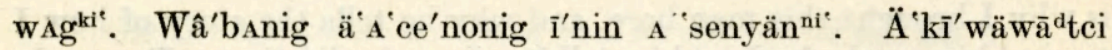

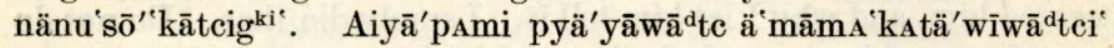
cä'cki wī ${ }^{\mathrm{d}}$ tci ${ }^{\prime} \overline{s o}^{\prime}$ mātcigki'.

Ä'wäpimenwipemenA'mowādtci mA'ni mī'cam ${ }^{\mathrm{mi}}{ }^{\mathrm{d}}$. NAgAmōna5 ni'gä īninimegō'nin ìni kegime ${ }^{\prime \prime}$ s äinādtci'megwa ki ma'ni mī''cāmmi'.

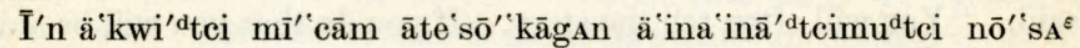
Ānawowāt $\mathrm{t}^{\mathrm{s}}$. 
a great offering to them. The next day the stones were gone. The buffalo hunters returned. When they arrived back (from where they came) they were fasting, that is, only those of their gens.

They began to take good care of this pack and the songs. Those songs are all exactly as has been narrated, and this sacred pack (also).

Thus, ends the story of the sacred pack as my uncle (father's brother) Anawat of ten tells it. 


\section{SOME LINGUISTIC NOTES ON THE TEXT}

The Fox text in the present volume is of considerable linguistic importance, as it differs in both content and form from any previously published Fox text. It is owing to these characteristics that we have a different vocabulary and that certain novel grammatical formations occur which are not discussed in the Fox sketch in the Handbook of American Indian Languages, Bulletin 40, B. A. E. The reader should thoroughly familiarize himself with Fox phonetic shifts before attempting to study the text, for with a knowledge of them much that is obscure will at once become transparent. ${ }^{1}$ It may be observed that such initial contractions as $\ddot{a}$ - for $\dddot{a}^{\prime} A$ - and $\ddot{a}^{\prime} i$ are quite common (e. g., $\ddot{a}^{\prime \prime} t \ddot{a} g i 52.33$ for $\ddot{a}^{\prime \prime}{ }_{A}{ }^{\prime} t \ddot{a} g i$ ). If the beginner keeps this in mind he will be greatly facilitated in consulting the list of stems.

The following grammatical notes are given as an aid to the comprehension of the Indian text. The paragraphs referred to are those of the grammatical sketch of Fox cited above.

$\S 8$. At $34.15-y$ - is used as glide between the stems ${ }_{a} g w \ddot{a}$ - "out of the water" and $\bar{a}$ cow $\bar{\imath}$ " "to cross," the final $\ddot{a}$ of $A g w \bar{a}-$ of course being changed to $a i$. It is also used as a glide at 32.38 between the stems $A$ "cä- "backward" and - $\ddot{a}$ - "to flee."

$\S 10$. Such contractions as metenō"megu'u $(40.32,40.33)$ for métenö imegu $u$ and aiy $\bar{o}^{\prime \prime} m e g u ' u(46.18,46.20)$ for aiyōimegu'u are common; uncontracted forms also occur.

$\S 12$. The $w$ of méto'sänenīw- (méto sänen $\bar{\imath}^{\prime} w_{\text {s }}$ "people") is lost before the instrumental particle $-m$ - in a verbal compound at 34.38 . See a close parallel in I. J. A. L. i, 50 (footnote 4).

$\S 28$. The effect of the formative element $-t u g^{k e}$ ( $\$ 14$ end) on the pronominal affixes is not touched on. In the text only a couple of difficult cases arise, namely, täpe $s i t u^{\prime} g \ddot{a}^{\prime} i g^{k i}$ " "they are probably pleased" (54.4) and kenene'käneme'götugke", "he has probably thought of you" (38.1).

$\S 29$. Both $\ddot{a}$ - and $w \bar{\imath}^{-}$- are used in the same verbal compound at 56.10. Previously (P. A. E. S. ix, 124) I pointed out the same thing in Kickapoo.

$\$ 30$. Certain forms in the text occur which contradict the table

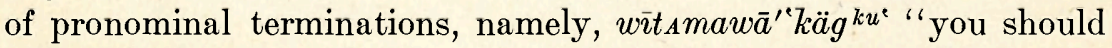
tell them (an.)," [at 44.17; potential mode], awit ${ }^{\varepsilon}$.... i ici kegeni-

${ }^{1}$ For such changes as aw to both $\bar{a}$ and $\bar{o}$ (due to the influence of adjacent sounds), $i$ to $e$ by vowel assimilation, etc., see p. 72 . 
$p y \bar{a}^{\prime \prime} k \ddot{a} g o^{\circ}$ " "you would not come quickly," awi'ta täpänemo'"KAgo ${ }_{A}$ "we should not be satisfied in our (incl.) minds" [potential subjunctives: see $\$ 35.6$; at 40.28 and 60.25 respectively], $k \bar{a}^{\prime} t_{A} \ldots$ inänemĩ'yägägku" "do not think of them (an.)," uwĩ'yawäwi $k \bar{a}^{\prime} t_{A}$ $k w \bar{n} n A t a^{\prime} w i$ cinawä' $\bar{\imath}^{\prime} y \ddot{a} g \ddot{a} g k u^{k}$ "do not try to trouble their body" [prohibitives; at 54.16 and 50.40, respectively].

\$33. A wholly anomalous intransitive inanimate plural in -gigi occurs at 32.7. The table contains a number of false forms which, however, are unimportant for this text. Other anomalous forms are mäyōwi'segini at 28.13 and mäyōwi'se'nigin at 28.28. At 18.3 a participial is found that begins with $\ddot{a}$ - which is proper to the conjunctive, not participial mode.

\$34. Amaw- appears as - $A$ mawo- before $-m e^{d} t c^{i}$, the third person animate of the conjunctive of the independent passive with obviatives as subjects, on which see I. J. A. L. i, 56: wäpi'sA $k a^{\prime}{ }_{A} m a^{\prime}$ wome $e^{d} t c^{i}$ " when the offering began to be made to him," 50.15 . See also 62.16 .

$-A m \bar{a}$ - occurs before the reflexive suffix $-t i{ }^{\prime}$ so-: see $58.29,42.42$. That this is an ancient formation is shown by the evidence of Algonkin, Ojibwa, and Montagnais: see Cuoq, Grammaire de la langue Algonquine, \$225; Baraga, Dictionary of the Otchipwe Language under wâbandamadis (nin); Lemoine, Grammaire Montagnaise, 53 bottom.

$-A m \bar{o} i$-, an anomalous formation though paralleled by $-A m \bar{u} h i-$ at Jones, Fox Texts 374.11 , is to be found at 60.7 .

$\$ 41$. There are a number of passive formations that occur in the text which have not been previously treated.

(a) Corresponding to $-m e^{d} t c^{i}$ of the conjunctive of the independent passive with obviatives as subjects, we have - mete $^{e^{*}}$ in the subjunctive: $k u^{\prime}$ "semete "if he were feared," 18.22 [with full-sounding terminal vowel].

(b) An independent passive in $-\bar{a}$ 'so- is found: minna $\bar{a}^{\prime}$ soyggwe "we (incl.) are given," 58.16. A similar formation is found in Shawnee. The posterior part certainly resembles the suffix -so- of the middle voice.

(c) A passive composed of the ordinary passive sign -gu- and immediately followed by a copula - $s i$ - for the animate, $-A t$-for the inanimate occurs: wï Aneminene'känetä'gu'sit "he is the one who will continue to be blessed," 40.43 ; āgwi wi Aneminene känetāgu" si${ }^{d} t c i n n i$ " "he will not continue to be blessed," 42.1; awi'tA neno'tägwA'teni's "it would not be heard," 58.23. Evidently the Kickapoo passive mentioned by me in Jones' Kickapoo Tales, 196, belongs here. Cree, Montagnais, Ojibwa, and Algonkin have a similar formation. It may be added that the $t$ of -At-disappears as usual 
before -'ki of the conjunctive: $\ddot{a}^{\prime} i n \bar{a}^{d} t c i^{\prime} m e g w A ' k i$ "as they (inan.) have been narrated," 66.5.

(d) An anomalous third person singular animate of the future tense conjunctive mode, independent passive, is to be found in wï $i$ cï $i$ cime sänemīnamegi " that he will thus be benefited," 52.41 . It was impossible to obtain a full series by questions based on this. Certainly -inamegi is related in some way to $-A m e g i$, the third person inanimate singular, conjunctive mode of the indefinite passive.

(e) A novel interrogative mode of the indefinite passive is $w \bar{\imath}$ 'Anemï̈̈cigän nīnapeme'ñ̄gänni' " whether I shall continue to be taken care of," 46.1. It was possible to obtain a fragmentary series based on $-\bar{\imath} g \ddot{a} n^{n i}$.

(f) The third person of a potential subjunctive of the indefinite passive is found a few times. The characteristic ending seems to be $-n \ddot{a}^{\prime} A^{\prime}$, but I do not fully understand the formation. See 32.17, $32.35,34.13,58.22$. The same forms occur in some of my unpublished texts obtained years ago, but they are extremely isolated.

(g) A novel indefinite passive -äweniwi- occurs a couple of times: änäwe'niwita "the one mentioned," 42.13; wĩanemipemepemenäweniwä $\ddot{a}^{\prime} \bar{\imath} y n^{n i}$ " [with $-w \ddot{a} \bar{\imath}$ - rhetorically for $-w \bar{\imath}-$ ] "I shall continue to be taken care of," 46.2. The same formation occurs in an unpublished text of mine: ${ }_{A}$ 'kawâpawen $\bar{\imath}^{\prime} w i w \bar{a}{ }^{d} t c^{i}$ " "they (an.) were watched."

(h) Examples of participials of the indefinite passive are to be found at $26.35,26.38$. They bear the same relation to the conjunctive mode of the indefinite passive as the ordinary participial to the ordinary conjunctive.

$\S 44$. The independent pronoun of the first person singular, $n \bar{\imath} n_{A}$, in combination with -megōni (see below) means "my very own": see 46.20 .

(a) A new demonstrative pronoun, $\bar{a}^{\prime} w a^{\circ} \bar{\imath} m(A)$, is found at 36.35. With this pronoun a person's name must be given. "So-and-so" is an approximate translation.

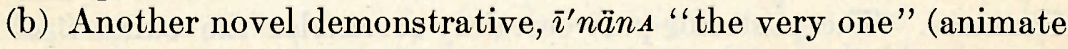
singular) occurs at $42.2,44.31$, etc.

(c) The combination ininimeg $\vec{o}^{\prime}$ nin (i) "the very same" (inan. pl.) is met at 66.5. Observe both members of the compound are inflected. The animate plural, inigimegōnigi, does not chance to occur in the text. With the posterior member of the compound compare nīnAmegōni: see above.

(d) An isolated word wīnānig(i), at 36.39, "her (his) people" evidently in some way belongs to the demonstratives as shown by the animate plural ending -igi, not nominal $-A g i$. It is a contraction of $w \bar{\imath} n_{A}$ and $\bar{\imath} n i g i$. 
We now come to a few points where reference to the grammatical sketch is impracticable.

I have treated loose verbal composition in the International Journal of American Linguistics, i, 50; hence it is quite sufficient to merely cite a few examples occurring in the text. See 38.22, 46.3, $50.27,50.28,54.33,58.26,58.35,64.42$. A peculiar free nominal compound is $k \bar{\imath}^{\prime} c i^{d} t c \bar{a}^{\prime} i k \bar{\imath} g \ddot{a}^{\prime} n u g i n i, 44.32$, a locative inanimate plural, "when gens festivals are finished," with the inclusion of the particle ${ }^{d} t c \bar{a}^{i}{ }^{i}$. The type of compound treated in the International Journal, i, 52 , occurs at 50.29 .

Transitive verbal forms with inanimate subject or subjects are not treated in the sketch save for the participial and possessed noun of the third person $(\$ \S 33,34)$. I regret to report that the table for the participial is very faulty in this respect as it is in others, nor is the treatment of the possessed inanimate noun entirely right. The Indian text in this volume shows that intransitive verbal forms with inanimate subject or subjects and animate object or objects, -gwi- immediately follows the instrumental particle and the ordinary animate intransitive verbal pronouns affixed, thus, winene"käne'megwits" (42.2) "the one of whom it will think," win nä sä $e^{\prime}$ gwiwädtci (50.35) "it will heal them," wri"wätä'säwi $e^{\prime} g w i y a ̈ g k w e^{*}$ (56.31) "it will make you warriors."

There is a peculiar construction with $-w e^{d} t c i$ for the conjunctive, -wete for the subjunctive which is to be found in the text, e. g.,

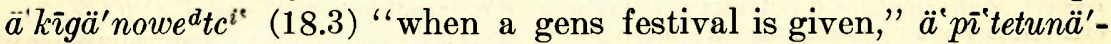

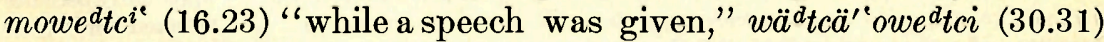

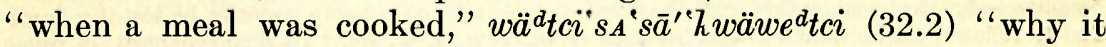
was against their religion," $i c a^{\prime}$ wiwet $^{e^{*}}(32.43)$ "if it were done." Obviously the $w$ is an instrumental particle and the terminations are the same as those for the third person animate, conjunctive and subjunctive of the indefinite passive.

The use of the formative element $-i$ - which occurs a number of times in the Indian text is quite baffling. The most I could get from informants by direct questions was that in at least some cases it made the word "sound sadder." Examples may be found at 28.15, 40.27, 46.27 .

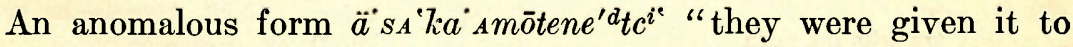
burn as an offering," is to be found at 50.17. Additional forms secured by interrogation failed to elucidate the medial $-t e-$. 


\section{LIST OF S'TEMS}

The following is a practically exhaustive list of all verbal stems which occur in the preceding text. As a matter of course I have included what must be regarded as verbal stems from the Fox point of view, whether or not they are from the English standpoint. A few nominal stems are included for convenience. The reader should be familiar with Fox phonetic shifts ${ }^{1}$ before attempting to use this list, for a stem is ordinarily only given in its original form, so far as this can be determined. It should be borne in mind that in some cases the material contained in the text is not sufficient to determine a given stem with absolute certainty. ${ }^{2}$ In such cases I have relied on

1 For convenience I give succinctly (not in detail) the most important phonetic shifts which are not in the grammatical sketch of Fox contained in the Handbook of American Indian Languages (Bull. 40, B. A. E.): $i$ becomes $e$ if the preceding syllable of a different morphological unit contains $e$; it becomes $e$ if the following syllable of a different morphological unit contains $\ddot{a}$; it becomes $e$ if the preceding or following syllable of a different morphological unit contains $u$; it becomes $e$ when immediately followed by the instrumental particles - $n$ - "by the hand," -ckaw- -ck- "by the foot," -cw- - $c$ - "with something sharp," - $s w--' s-$ "by heat," even when they are conventional in meaning, as well as by the copula -'si-; $i$ becomes $\imath$ when accented if followed by $y$ or $w$ as well as on the penult when followed by $w$; it becomes $\bar{\imath}$ before the instrumental particle - $k a w-$ - $^{\prime} k-;$ it probably becomes $e$ before the instrumental particle - $t a w--t$-; the combination -iwä-, where the $\ddot{a}$ is not in the same unit as the $i$ becomes -ow $\ddot{a}-$; the combination $-w i$ - between consonants becomes $-u$ - (- $\bar{o}-$ also $?)$ under the conditions whereby $i$ normally becomes $e$; o becomes $u$ before -pw-and -gw-; o becomes $\bar{o}$ before $-w A$; in the combinaticn of stems $-\ddot{a} \bar{a}-$ becomes $-\ddot{a} y \bar{a}-$; similarly $-\ddot{a} A$ - becomes $-\bar{a}-$; under the same conditions $-\bar{o} A$ - becomes $-\bar{o}-$; it is not certain whether under like conditions $-\ddot{a} e$ - becomes $-\ddot{a}$ - or $-e-$; under what conditions $i$ apparently becomes $\boldsymbol{a}$ is not known; $-w A$ - between consonants becomes $\bar{o}$ for the most part; $-y_{A}$ - between consonants becomes $-y \ddot{a}-$; the combination -ew $\bar{\imath}^{t}$ - becomes $-\bar{\imath}^{\prime}-;-w$ - after consonants seems to be lost if $u$ immediately follows; the combination - $a w$ - becomes $-\bar{o}$ - before $n, y, w, a t c, t$ (in final syllables), $-\bar{a}$ - before $g$ and $t$ (normally), terminally $-u^{*} ; n$ becomes - $c$ - before $i$ which is a new morphological unit; under like conditions $t$ and $s$ become $d t c$ and " $c$ respectively; the combination of $n y$ when not in the same unit seems to become $n$.

${ }^{2}$ It should be borne in mind that every transitive, middle, and passive Fox verb (with a few exceptions) requires an instrumental particle, whether these have retained their original meanings or have become purely conventional in use. As these are inadequately treated in the above-mentioned sketch, I give here the principal ones; the meanings are given when the particles have not become conventional. The arrangement in columns as presented here is novel.

\author{
With logical animate object \\ $m$ with the mouth \\ m \\ $\mathrm{w}$ \\ 'w \\ 'pw with the teeth \\ $\mathrm{n}$ with the hand \\ n \\ 'cw with something sharp \\ "sw by heat \\ "ckaw with the foot \\ "ckaw \\ naw \\ taw \\ 'taw \\ 'kaw \\ gaw \\ 's
}

With logical inanimate object. 
my general knowledge of Fox, some grammatical notes on the text ${ }^{1}$ obtained from Edward Davenport and Harry Lincoln, the evidence contained in Jones' Fox Texts, and the published Cree, Ojibwa, and Algonkin material. As a result the number of uncertain stems has been reduced to a minimum. ${ }^{2}$ In every case a few references are given to the text by page and line to further facilitate its study.

Stems which can not occur in initial positions are given with a hyphen before and after them. The list shows how much more numerous the stems which occur in initial positions are than those which can not. It also shows that copulas are far more frequent than is indicated in the Handbook of American Indian Languages, Bull. 40, B. A. E. It should be constantly kept in mind that these copulas can not be used indifferently with any given verbal stem, but, on the contrary, are restricted in use; so that their actual usage must be learned by rote.

It has been a matter of some difficulty to assign the meanings given the stems on account of their weak, almost colorless, meanings by themselves. It is only when stems are combined with each other or with instrumental particles, and according to the context of the sentence in which they occur, that very definite senses can be assigned to whole combinations. The beginner may be cautioned that a few homonyms occur. Stems occurring solely in the songs are not included.

The following alphabetic order has been adopted: a, a, s, â, ä, e, i,

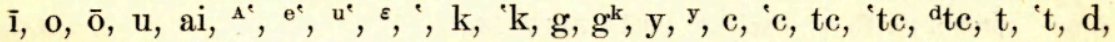
$\mathrm{s}$, 's, n, n, p, p, b, m, m, w, w. For a tabular view of the phonetic elements of Fox as I conceived them, see pages 12 and 13 .

awA- fetch, carry. ${ }^{3} \quad 30.34,32.18,48.25,50.21,62.37,64.34$.

awi- be, dwell (not the copula, nor anxiliary). 18.2, 18.32, 36.10, 36.39, 38.6, 38.33, $42.10,46.11,50.41,52.22,62.11$

$\bar{a}$ - use (-w- inst. with an. obj.; -t- inst. with inan. obj.). $14.16,30.39$

ä-, ä- go. 20.9, 32.36, 36.31 (twice), 36.32 (twice), 38.33, 38.45, 40.9, 40.21, 40.24, 44.42

-ā- be (inanimate copula). $34.7,34.11,40.26,40.35$

-ā- flee. $32.19,32.38,32.39,62.35$

-ā'kä- throw. $58.19,62.3,62.6$

$\bar{a}$ 'kowi- rear. $34.8,34.10,64.19$

-ā'ku- meaning? 32.35 (twice), $34.3,34.9,56.7,60.27$

$\overline{\mathrm{a}}^{\mathrm{k}} \mathrm{kw}$ - weapon, arm. ${ }^{4} 32.37$

$\bar{a}^{\prime}$ 'kwamA- be sick (in Fox a transitive verb). 30.34, 30.41, 50.20, 64.14

$\bar{a}^{\prime} k w a ̈-$ be angry. 18.22

$\bar{a}^{\prime} k w \bar{i}-$ error for A'kwi-? 34.11

-āgi- meaning? (used with ketemi-) 50.37, 58.5, 58.10. (Used in Cree, Algonkin,

Ojibwa with correspondents to ketemi-; Kickapoo also.)

-āgō- be related to. ${ }^{5} 44.25,54.11$

1 See footnote, p. 9.

2 Where the stems do not agree with those given by me previously, the latter are to be superseded.

3 Jones awA-.

1 A few nominal stems are included in this list for convenience.

- Evidently -aggo-is related to wägō-as-äpA-is to wâpA-. 
āgwA- pile. $32.42,44.20,44.23,48.7,48.42,50.1,60.25,64.23$

$\bar{a}^{\text {'ci- }}$ teach. 34.40

$\overline{\mathrm{a}}$ 'cowi- cross. $34.7,34.9,34.11$ (twice), $34.16,40.27,40.30$ (reduced in the last two cases).

ā'ckā-, ā'ckä- fall. 62.4, 62.7, 62.34

$\overline{\mathrm{a}}^{\mathrm{d}} \mathrm{tci}-\mathrm{anew}$, change, move. $14.12,44.12,60.11,60.12$

$\overline{\mathbf{a}}^{\mathrm{d}}$ tci- tell of. $24.6,30.35,36.27,36.35,38.3,38.13,38.32,40.1,48.10,48.30,48.31$,

$54.23,60.17,62.3,62.15,62.22,64.1,64.15$

$\bar{a}^{\mathrm{d}}$ tcipanAgi ${ }^{\mathrm{d}} \mathrm{tci}-\mathrm{all}$ sorts of ways. $52.12,60.20$

-āte- live. 44.35, 44.36, 60.11

ātawa'ā- repeat. 52.19

āto- relate, speak. $34.41,56.39,64.1$

ātowā-, ātowä- speak an alien language. 62.38

$\overline{\mathrm{a}}$ 'sō- support. $50.23,52.15$

ānawi- inability. $32.24,50.20,52.11$

ānagi- accustomed to. $28.36,46.34,46.45,48.1$

āne'käwi- in succession. 54.33

āne'kō- lengthen. 30.18

ānwä- disbelieve (with -'taw- -'t- instr.). $38.18,64.37,64.38$

ānemi- overpower. 18.21

ānwi- fail, be unable. 64.42

-āniwi-1 ${ }^{1}$ meaning? last, endure? 46.25

-āps- see $^{2}$ (derived from wâpA; Cree and Ojibwa similarly). 58.11, 64.28

-āps- dawn, derived from wâps-; same ultimately as -āps- see. $20.34,46.31,46.34$ āpi- untie. $16.32,32.27,44.20$ (twice).

-āpi- see, look at (-âpi- after w). 50.30, 52.6, 52.8, 52.10, 58.26

-āpowA- food. 30.34

-āpyä- extend; with pemi- flow (of water). 40.25

a'pa'wā-, à'pa'wä- dream. 36.41

$\bar{a}$ 'pe- forever (with -t-, ${ }^{\mathrm{A}} \mathrm{tci}$-). ${ }^{3} \quad 20.14,34.37,54.34$

ā'penā-, à'penä- be diseased. $44.30,52.12,54.19$

$\bar{a}$ 'pene- alike. $42.24,58.33$

$\bar{a}$ 'pì- extent, duration (with -'t-, - 'tci-). ${ }^{4} \quad 16.23,30.39,44.44,46.27,58.1,58.21,58.25$, $58.28,60.33$

-āme'ki- earth. ${ }^{5} \quad 42.45,48.36,48.37,56.28$

1 The text in the current syllabary and the text restored phonetically by dictation support the form; but from Jones's Fox Texts at 378.6 it would appear that at $46.25-\bar{a}$ winigwänn ${ }^{i^{*}}$, not -ānìwigwän ${ }^{\mathbf{a}^{*}}$, should be read. The stem then would be -âwi-.

2 -âpa-after w.

3 As I have shown on another occasion, the so-called "intervocalics" are an illusion. What we really have are post-verbal extensions. At the present time it is not known under what conditions these are used. These "extensions" run in sets: -t- -dtci-, -'t- - tci-, -n- -ci-. Strictly speaking, it is probable that the "extensions" should be given as -t-, - $t-,-n-$, for $t$ ' $\mathrm{n}$ respectively become dtc " $t c$ 'c before $i$ which is a new morphological element, and -t- - $t$ - - n- are used, and not -dtci- -'tci- 'ci-, before e in positions where $i$ would be converted into e (for example, if the following syllable of a different morphological unit contains ä), as well as in cases where iwä becomes owä, and also where an $\mathrm{i}$ is lost before -wäwä-. That is to say, the - $i$-is also a morphological element. Insofar as -e-is used to prevent consonantic clusters foreign to the Fox language, a certain amount of doubt is thrown on the above reasoning. Theoretically a list of Fox verbal stems should show what verbal stems can be combined (for synthesis of stems does not universally hold true), and in the case of copulas the sets which go together, what pair of "extensions" go with any given stem and how they are used, what instrumental particles go with any stem (in some cases several), and in what position the stems occur. But an enormous mass of text-material would be needed to show this. So far as the writer knows Sauk, Fox, Kickapoo, Cree, and Ojibwa agree entirely as regards these points. Hence it may be presumed that at least all Central Algonquian languages do.

4 In texts dictated by Harry Lincoln recorded as $A^{\prime}$ pi-; the evidence of Cree favors $A^{\prime}$ pi- as being the original Fox form. (Note A'pi- at 34.27.)

s In another text the same author has used -āme'kwi- consistently. 
āmi- contrive. $18.34,30.10,32.13,32.27,32.42,44.4,44.14,54.29,58.28,60.37$

āmi- move. 34.14

āwA'si- more. 34.27

āwi- own (?) 18.22

A- be (placed), happen (with inanimate auxiliary -'tä-). $30.20,48.11,60.38,62.4$, 64.44

A- own, possess ${ }^{1}$ (-'s- inst. for an. obj.; - 'taw- inst. for inan. obj.) $16.12,16.33,30.2 \mathrm{I}$

(twice), $30.23,32.37,42.41,50.27$

-A- eat. 32.20

A'kA- burn. 18.9, 18.10, 18.11, 60.44

-A'kami- land (substantival). 54.37

A'kwi- tired, exhausted. $32.40,32.42$

$\mathrm{A}^{\prime} \mathrm{kwi}-$ as far as. $54.37,66.7$

-A'kwä- course (of sun). $18.16,28.32,34.30$

Agāwā- desire, want (with -n- -t- inst. part.). $\quad 60.23$

Agwâ- out of the water. $34.15,34.19$

Agwapi- bandage. 30.23

A $^{\circ} \mathrm{CA}^{-}$feed. $32.3,32.4,36.13,36.27$

A cä- backward. $32.38,32.39$

A'ceno- disappear, be absent. $34.38,46.1,48.9,66.1$

A'ci- make. $38.28,40.27,48.12$

-A'ckā- downward, probably same as ā'ckä-, ā'ckā- fall. $\quad 62.12$

$A^{\circ}$ cki- raw. 46.24

A'cki- first. 14.7, 16.17, 36.12, 38.21, 44.16, 54.5

A'ckipagi- green. 56.28

A'ckwi- save. $42.41,42.42,62.13,62.14,62.36$

-At- be (an inanimate auxiliary). 32.37

Atā'p- pick up. $32.29,60.25,60.26$

-AtA- whip. 62.35

AtAmā-, Atamä- smoke. $14.16,14.17,14.20,16.22,16.23,16.32,26.10,30.38,44.29$, $44.30,44.34,52.27$

-Atä- width. 34.1

Atenāwi- less. $34.28,42.22$

Atō- exact meaning? 14.24

A sāmi- too much. $36.43,38.7,56.7$

A'semi- help. 44.6, 50.38

A'sipō- group. 14.24

A'so- support (error for à'sō-?). $\quad 28.30$

-An- inan. copula. 46.22

Anāgwi- evening. $28.33,28.35,36.6$

Ane'ki'i- little. $32.20,62.2$

Anemi- continue. $18.8,18.10,18.15,32.18,32.25,32.36,32.38,34.6,40.9,42.44$,

46.19 (twice), 48.26, 56.26, 56.27 (twice), 56.28, 56.29, 62.1, 62.7, 62.35, 64.20, 64.21 Ano'kā-, Ano'kä- order, send. ${ }^{2} 48.31$

Anwā- willing; with post-verbal -t-, - ${ }^{\mathrm{d}}$ tci-. 60.5

Anwäwä- sound (transitive) (a fossilized compound). 14.6, 16.33, 18.15, 18.17, 18.23,

$20.32,20.33,20.34,20.41,20.42,24.1,24.2,26.8,26.34,28.14$ (twice), 28.19

Api- sit, stay, be (not copula). 16.24, 18.28, 18.29, 28.27, 28.31, 44.8, 48.3, 52.31, $52.39,64.43$

A'pi- upon; with -äne- (q. v.) depend upon, put trust in. 50.34

Ami- be set, placed. $20.2,30.4,64.43$

1 Probably same in origin as A- be (placed).

2 In texts dictated by Harry Lincoln, Anō'kä-. The literal translation is "that he should give orders," but the idiomatic meaning is "that he should give orders for them to hunt for game." 
-ägi- hide (nominal). 30.22

-äne- think (with -m- -t- instr.). 42.21, 42.25, 42.26, 42.28, 44.15, 44.41, 46.13, 50.12,

$54.3,54.16,54.29,54.31,56.16,56.19$

-änī- copula? 46.24

-äno- meaning (?) probably not a true stem. 40.37

-e- inan. copula going with -et-. 46.26

-e- copula used in iterative numerals; goes with -en- (e. g. negutenwi "once"). $24.34,28.13$

-e'kā-, -e'kä- make tracks. ${ }^{1} \quad 64.20$

-egä-, -egā- dance. 14.35, 20.41

-et- an inanimate copula. $40.8,56.36$

-en- copula used in iteratives of numerals. 20.34, 42.8

i- say, name (-n- -t- instr.) $34.32,34.33,34.39,34.41,36.17,36.30,36.35,36.36$, $36.43,38.4$ (twice), 38.14, 38.39, 44.3 (twice), 48.14, 56.22, 58.2

i- thither. $32.36,40.24,44.42,64.27$

-i- copula, auxiliary. $14.34,16.37,30.1,32.32,32.34,44.5(?), 54.25$

-igā-, -igä- an auxiliary. ${ }^{2} \quad 48.31,58.7$

i'cawi- do, happen. 18.24, 32.11, 32.27, 32.42, 32.43, 34.17, 38.1, 40.23, 44.2, $46.32,48.24,54.10,58.17,58.29,60.5,60.6,60.26,60.31,62.29,64.2$.

i'ci- toward. $20.34,30.11,46.31,62.9$

i'ci- thus. 14.1 (twice), 16.34, 18.40, 20.36, 24.7, 26.37 (twice), 28.25 (twice), $28.29,30.28,32.8,32.29,36.22,40.8,40.24,42.24,44.7,44.14,44.24,44.38,46.13$, $48.17,50.42,52.24,52.25,52.35,54.3,54.30,54.31,60.39$

-itä- feel (mentally). 32.29, 36.23, 44.5, 44.7, 44.18, 46.23, 48.18, 52.35, 56.3, $58.5,58.10,58.39,58.45$

ite- happen to. 56.6

i'sō- name. 14.1 (twice), $18.40,34.25$ (twice), $56.17,58.38$

in- thus, goes with i'ci-. $36.41,38.19,42.21,42.22,42.24$ (twice), 46.45, 48.1, 50.12, $52.40,54.10,54.28,54.29$ (twice), $54.31,56.19,56.20$

in- direction toward; goes with $\mathrm{i}^{\prime} \mathrm{ci}$ - (same meaning). $30.4,46.34$

inät- be absent. $18.31,18.38$

inowä- tell, say, boast (in origin a compound of in- thus and -wä- sound; see p. 72). $60.20,62.43$

igi- dwell. 16.12, 38.7, $46.7,62.36$

-igwā-, -igwä- eye (substantival). 50.24 (twice), 52.9

iw- marry (strictly only the nominal stem iw- wife). $44.25,64.8$

-ō'i- suffix or stem? meaning? rhetorical device? 14.31, 26.12, 26.35, 30.16, 32.4

-ō- carry on the back (cf. nō-). $64.29,64.32$

u- whence (with -t-, - ${ }^{\mathrm{d}}$ tc-). 18.12 (twice), 18.26, 20.14, 20.16, 20.34 (twice), 20.35 (twice), 28.30 (twice), 44.4, 46.25, 46.31, 46.32, 46.33, 48.27, 54.17, 58.13, 58.24, 60.3, $60.27,64.11$

-u- meaning? used with kep- (similarly in Cree and Algonkin). 62.32

utami- hinder (from u- and -Ami-?). 40.25 (twice)

-u'sä- walk. $32.6,48.38,62.15$

upi- glad. $58.9,58.14$

aiyāpami- back. $62.15,62.33,66.2$

aiyigwāmi- endeavor, do one's best. $44.11,44.37$

aiyō- use. (Does not employ an instrumental particle). 18.34, 20.32, 20.39, 22.28, $26.34,30.12,30.32$

-`ā-, - -ä- auxiliary. 16.38, 16.40, 32.29, 36.23, 44.7, 44.18, 46.23, 48.18, 50.42, 56.3, $58.5,58.6,58.39,60.19,60.36,60.37$

kā'kī'kī- scratch. 32.15 (twice)

1 Apparently connected with -gā-, -gä-; but there are phonetic difficulties.

2 Formerly given as -"kā-, -'kä-; e'ckā., -e'kä- probably correct. 
kāgigä- forever. $54.41,54.43$

kāta- start (of songs). 20.42

kā'cki- discover; with -'taw- inst. hear. $32.23,48.41,54.13$

-kA- leave. ${ }^{1} 44.43$

kA cki- ability. $30.18,62.10$

katawi- nearly. 16.6, 30.41, 34.26, 50.29, 64.22

kAnaw-, kAnō- speak (-n- -t- instr.). 14.35, 16.37, 36.42, 50.14, 50.15, 50.25

-kanä- bone ${ }^{2}$ (substantival). 28.39, 28.41, 32.10 (twice)

-kami- expanse, latitude. 40.30

-kamigi- household. 50.19

-ke- an inanimate copula (goes with -ken-). $44.13,44.36,46.6,46.40,52.9,60.22$

ke'ka- select (probably modification of ke'ki-). $28.42,48.2,48.31$

ke'ki- know. $28.38,46.13,52.25,52.27,54.36,58.40$

ke'kyā-, ke'kyä- very old. 18.28, 18.30

ke'kye tenāmi- certainly, convincingly. ${ }^{3} \quad 38.10,38.19$

kegeni- quickly. 40.28

kegi- be with, have. $30.11,44.30$ (twice), 56.1, 64.29

kegyäp- blind. 50.24

ke'cawi- loose. 58.22

ke'cipi- itch. $30.42,30.43$

ke'tci- intensity (really ke- with post-verbal -'t-, -'tci-). 36.36, 38.6, 64.44

ket- take off, lift off. $16.27,64.32$

ketemi- wretched, piteous; with instrumental particle -naw- take pity on, bless.

$34.24,34.26$, 40.18 (twice), 42.44, 44.3, 44.4, 48.19, 48.43, 50.7, 50.26, 50.37, 52.39,

$58.15,60.41$

keto- hoot. $36.2,36.6,48.40$

ke't- old (a derived meaning; see ke'tci-). 16.14, 48.30

ke'si- cold. 18.12, 20.35

kena- forbid, hinder. 64.42

kenā- slowly, softly (with -t-, -dtci-). 42.17, 44.21, 62.9

kenwi- long. 40.29

kepi- inclose, surround. 62.32

-ki- grow? same as -gi-? 40.35

kī- ail. $30.18,32.8$

kïgäno- give a gens festival. $16.30,16.36,18.9,30.24,44.23,56.45$

kigi- strong (of animals and human beings only). 60.27

kïcāgu- as much as possible (with -t-, - ${ }^{\mathrm{d}}$ tci-). $36.11,52.8$

kïci- completion. $14.9,16.5,16.6,20.42,28.34,36.22$ (twice), 36.38, 38.21, 38.25,

$38.32,38.40,38.43,50.33$

kī'cki- cut. $32.12,32.25$

kï'sā- wound. $30.3,30.36$

kīsā- attach. 42.30

kini- sharpen. 18.7

kïpu- be filled (with food). 64.5

kimi- secretly. 36.13

kīwānī- be lost. 46.36

kiwä- return. 66.1

kiwi- go around. 18.22, 32.42, 44.30, 64.11, 64.15

kō- center? (true stem?). 52.2

ku- fear (with -'s- -'t- instrumental particle). 18.22, 62.33, 64.8

1 -"kA- in texts dictated by Harry Lincoln.

2 Exact phonetics uncertain; perhaps -ganä-; another text favors -kanä-.

${ }^{3}$ Evidently derived from ke'tenna' surely, truly. 
ku'ki- change. 56.28

kudtci- try, ought. 54.36

kyā- hide, keep secret. $46.15,56.32,56.33$

kwāgōō- cry at the top of one's voice. $50.2,50.6$

kwāpi- scatter. 62.11

kwinatawi- sorrowful. $50.40,52.24,52.36$

kwaiyā- already (with -'ci-). $56.5,56.10$

-'kā-, -'kä- do, perform; nouns lose a part of their noun-forming elements before this. $34.18,40.11(?), 40.30,44.29,46.21$

-'kamā-, -'kamä- smoke (of tobacco). 16.22, 44.4

-'ke'ckā- in pieces (?). 62.11

-'kyä- an auxiliary. 48.31

-'kwä- head (substantival). 14.12, 28.31

-gā-, -gä- animate auxiliary. $34.35,50.18$ (twice), 60.2 (twice), 60.36

-gāpā- stand. 20.2, 20.40, 30.4, 30.11, 32.34

-gA- an inanimate copula; goes with -gAt- $54.37,60.13,64.31$

-gA kwanä- leg, shin bone. 32.7

-gat- inan. copula; see -gA-. $18.20,30.16,30.26,32.4$

-ge- inan. copula; goes with -gen-. $18.20,30.18,30.19,32.9,34.1,40.8,50.39$

-gi- mature, grow. $14.9,34.27$ (twice), $36.18,36.22,36.34,38.21,38.31,38.35,38.36$,

54.17

-guna- day (derived from -guni- by vocalic harmony). $28.36,30.26$

-guni- day (see-guna-). 28.34, 30.37, 48.31

-gumä- projection from a base, point, nose (idiomatically). 18.7

-gwA- an auxiliary, used in inan. indef. passive; goes with -gwat-. 66.5

-gwat- auxiliary, used in indef. passive inanimate. 58.23

-gwä- face (nominal). $34.31,46.31,46.33$

-(y) $\bar{a}^{\prime} k w i \quad$ slanting. ${ }^{1} \quad 28.30$

yā- go. $16.27,40.22,40.24,62.15$

yā- meaning? 50.18

yāwi'ci- one after the other (?). 26.35

yä- still? (temporal); collateral form of yä'ci-? 20.14

yä'ci- still (temporal). 38.28

"cā-, -"cä- ear. $38.8,42.5,58.39,62.40$

cāgwa- chew. 32.22

cä'cki- not put on (idiomatically refers to not putting charcoal on the face). 34.31 cegi- lie down. $28.20,38.23$

cegwi- very (?) (obsolete). 62.28

cī'cā-; cī'cä- hunt. $34.21,48.28,62.13,62.30$

-ci- place (transitive), lie (see -'cin-). 14.12, 18.26, 28.30, 28.31, 46.31, 46.33, 64.43

-cin- lie; almost as if animate copula; animate subject only. 44.12

-cki- sort, kind. $30.22,34.2$

-ckwi- meaning? used in combination with āpi-; similarly Cree, Ojibwa, and Algonkin. $32.27,44.20$

tcapōgi- motion into water. 34.13

tcāgi- all. $34.10,48.39,50.19,62.2,62.12$

tcA 'kwi- short. $34.7,40.26,56.7$

tcagi- small, little. $42.12,42.17$

tcäw- both (cf. tcäwīcwi both). 34.27

tcigi- edge. 34.16

Is the $y$ merely a glide? 
tcit- on? (used only with Api- sit). 28.21

tcinawä- be related to. $54.11,58.10$

tcipi- move (of eyes). 54.4

$-{ }^{\mathrm{d}}$ tcä- belly. 64.5

-dtcäpika- root. 32.44

-t- an inanimate copula (-et-?). 42.14

tā'tāpō- lengthwise. 18.26

tagwi- together. $30.19,32.20,38.12,40.35$

tA ${ }$ ci- there, then. ${ }^{1} 18.22,38.16,46.21,50.18$

tA'swi- as many as. $30.24,30.37,44.23$

tan- then, there; goes with tA ${ }^{\prime}$ ci-. $14.12,16.25,28.31,36.7,36.41,38.5,38.9,58.27$, 64.4

tan- activity, engage in (idiomatically sometimes "fight"). 20.16

-tä- inanimate copula; used also in indefinite passive or middle. ${ }^{2} 32.7,36.16,40.42$, $46.26,46.27,46.29,48.40,52.2,52.33$

täpi- please, satisfy. $40.11,40.13,40.37,48.16,50.41,54.37,56.13$ (twice)

täpwä- true; with - 'taw- instrumental, believe. $34.36,40.42,40.44,56.25,58.17$

-te'kā- call, name. ${ }^{3} \quad 40.4,40.42,56.2$

tetepi- circle. $52.5,52.11,52.13,52.15$

tep- own, be master of (with -äne-). 54.25

tepā- be fond of, love. $44.25,64.20$

-tepā-, -tepä- head (of body). 16.15

-temi- depth. $34.7,34.11,40.26,40.30$

tote- improperly cooked (raw, or burned). 46.22

tō- treat (with -taw- -t- instrumental). $60.21,62.16,62.39,64.1,64.3,64.12$

-tunä- mouth, point, speak. $16.1,16.23,23.25,28.37,46.34,48.1,48.6$

-'tä- an inanimate auxiliary. $30.20,30.21,46.22,48.11,60.39,62.4,64.44$

sā'kwä- against custom, rules, religion (always reduplicated sA'sā-). 16.7, 16.16, 32.2,

34.18

sāgi- forth, exposed to view, grow (idiomatically), outside (idiomatic). $18.33,46.40$

-sA- sudden. 32.27

-'sA- meaning? 16.35, 28.14, 28.19

sA "ka- burn (as an offering). 50.6, 50.8, 50.10, 50.15 (twice), 50.17, 64.44

sagi- seize. 62.5

sanagi- difficult. $34.32,54.19,60.13,60.27$

-'se- collateral form of -'sen-, inan. copula, place; sometimes, with -n- instrumental,

has an animate object. $20.43,28.13,28.28,46.30,46.34,56.28,58.21$

se'swa- spit on. $32.12,32.13,32.17$

siga- pour, serve (probably derived from siggi-). 14.26

si's- graze (barely touch). 32.14

-'se'kā-, -'se'kä- motion. 54.18

-'senyä- eat (seems in some way related to wi'seni-). 36.13

-'si- be (animate copula). 16.27, 20.14, 60.15

-'sigā-, -'sigä- cook. ${ }^{4} 30.33$

sōgi- bind, tie, hold. $20.3,30.21,32.36,62.10$

na'i- know how, practice. $16.8,28.36,44.13$ ?, 64.7

nawa ${ }^{\text {dtci- }}$ stop to. $20.36,24.3,34.20$

na'wA'pwā- provision for travel. 64.6

\footnotetext{
1 Another stem tA'ci-in some way is connected with tA'swi-number, as many as.

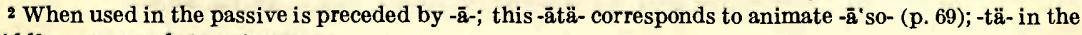
middle corresponds to animate -so-.

3 The exact form of this stem is not easy to determine; the form given is quite provisional. Similar difficulties occur in cognate Algonquian languages.

1 Converts preceding i to e, and wi to u; nemenu'sigku', I cook well.
} 
-nawä- thereby. $38.15,48.15,48.16,50.40,52.24,60.13$

nā- fetch. 50.22

nā'kani- entire (of time). $16.9,16.29,28.16$

nā'ku- hum. ${ }^{1} \quad 16.39,16.40,28.26,60.2,60.6,60.36$ (three times), 60.37

-nāgä- sing. 16.6, 16.34, 20.4, 24.7

nāgwā-, nāgwä- depart. $20.5,20.9,38.41,48.30,64.40,64.42$

nātA'swi- several. 30.15

nā's- toward. $30.4,36.10,64.43$

nāwi- middle. $18.16,28.32,34.30$

nA- attack. 62.8

$\mathrm{nA}^{\prime} \mathrm{ku}-$ assist in singing. 20.9

nAgA- sing. $16.30,26.13,56.38,56.40$

nAgA- leave. 64.17

nataw- desire. $46.9,50.36,58.28$

nato- ask, seek. $16.3,46.13,50.10,58.3,4,62.7,8,64.26$

natupani- war (verb). 18.14, 20.1, 32.11

nana i- ready, comfortably. $20.40,30.33,40.16,42.45,48.42$

nanā'kawi- evil. 56.18

nanagi- nervous. 60.15

nanagu- space between the fires of a wickiup. $48.40,52.33$

-nAme'ckä- skin. $30.1,32.16,32.31,32.33,38.44$

nä- see (with -w- -t- instrumental). $46.37,46.39,46.42,48.7,60.24,62.7$

-nä- meaning? same as nä-? combined with nato- means seek (with 'instrumental). 40.26

nä'sā-, nä'sä- be cured. $30.26,30.39,50.35$ (twice), 52.16

ne- kill (with -'s- inst.). $46.9,54.8,62.30,62.33$

ne- recognize (with -naw- -n- instrumental). $40.2,40.4$

-ne- pursue, drive (with -'kaw- -'k- instr.). $32.41,60.11,60.12,62.35$

-ne'kä- hand (substantival). 32.8

ne'ki- set (of sun). $16.8,18.17$

-negwä- arm (substantival). 62.5

ne'ci- alone (see ne's- alone). $48.3,48.27,54.34$

ne'ciwi- dangerous; in transitive verb, endanger, overpower. 18.19

ne cki- scold (with -m- instr.), hate (with -naw- -n- instr.); forbid is a derived mean-

ing. $30.42,36.26,36.28,44.17,44.23$

-ne ${ }^{d}$ tcä- hand (palm and fingers only). 30.11

ne's- alone (see ne'ci-). $18.28,18.29,18.30,18.39,20.3$

nene'ki- mindful. $38.24,38.29,56,16,58.45$

neno- understand, hear (with -'taw -'t -inst). $36.1,36.2,36.4,42.12,56.42,58.23$

nenyäpi- nervous. 18.25

nep (ō)- die. $28.15,28.18,30.16,50.29,54.42$

nepā-, nepä- sleep. $28.20,28.22,28.23$

nepwā'kā- be intelligent. 48.15

nemA- stand. 48.34

nịgāni- in front, head. $14.32,20.40,34.6,48.26,50.4$

ni's- dismiss. 52.14

ninawi- weaken. 56.34

nimA- fasten in the hair. $14.7,14.10$

nimi- dance. 14.7, 14.9, 20.40

-no- termination, destination (?); with -taw- -t- instr. $44.2,44.42,56.4$

-nowA- get (?). 60.26

nowi- go out. $16.9,16.26,18.33,52.7$

1 For reasons unknown to me, nä'ku-, with "change" as if from nA'ku-, occurs. 
nō- hear (with -taw- -t- instr.). $\quad 44.14,50.33$

nō- carry on the back (with -m- -t- instr.) 20.1, 20.4, 34.3

nō'k- soft, fresh (idiomatically). 46.27, 48.36, 48.37

-pa'o- run. $32.39,64.27$

pā'kā'ku- dismiss. 34.21

pā'tā- injure, wound. 28.41

pāmi- indefinite motion. 52.14

-pa- sort, kind (inan.). See -pan-. 14.30

pA ${ }^{\circ} \mathrm{ki}$ - dismiss, permit. $52.17,56.9$

$\mathrm{pA}^{\prime} \mathrm{ki}$ - separate (probably same as $\mathrm{pA}^{\circ} \mathrm{ki}$ - dismiss). $\quad 32.5$

- pA'kwi- remove. 16.22

pag- arrive at termination (?). 34.7 .

pAg A- strike. $20.36,58.7$

pagi- fall down; with -ci-, go down (of sun). 20.35

pagi- throw. $40.19,52.4$

pagōci- ahead. 64.24

pA'ci- even (not even will I save, etc.). 42.6, 42.42

pA'cki- break, part. 52.8.

pA 'tA ka- spear (verbal). $18.7,18.8,18.9$

pA's- swift contact. 42.5

pan- lose, miss. 58.11

-pan- sort, kind (inanimate) (see -pA-). 14.31, 26.11, 26.35

panā- ruin, spoil; with the extensions -t-, - dtci-. 18.21

pe'ki- especially, very (same as the adverb). $26.38,26.39$

pe'ku- night. 28.23

pe'kwi- thick, "bunched" (slang sense). $32.9,32.10,48.7$

pegi- break. 62.11

pe'cigwi- upright (literal and metaphorical). $48.4,56.33$

pe'tci- accidentally, inadvertently (really pe-; note pe't- also is found). 48.20

peta'sagi- go wrong with. $40.23,40.29$

pe's- listen. $38.8,44.15,58.39,62.40$

peninawi- take off (clothing). 16.27

peno- go home. $16.12,16.16,20.11,36.30,48.25,62.29,64.5$

pepō- be winter. $18.2,18.10,56.29$

pem- take care of. ${ }^{1} \quad 34.30,36.24,46.2,54.34,66.4$

pemi- along, begin, during. $30.41,46.8,52.5,52.7,60.11,62.35$

pemw- shoot. $32.1,32.41$

-pi- sit; really Api- if the combination -A A- becomes -A-. $44.23,64.23$

pigä- exhausted, tired out. 32.40

pitA- bury; with 'w instrumental. 28.32, 28.33, 28.34 (twice)

piti- enter. $16.15,50.18,64.16$

pï'si- small, tiny, fine. 32.4

pine cì- attack, "start something" (slang sense). 64.12

pō'kwi- break. 18.24, 28.41, 32.7

pōtā'kwā- place in a kettle (to cook). 48.39

pōni- cease, stop. $38.9,38.10,50.30$

pönī- camp. 18.18, 34.15

päwi- light, little (metaphorically). 44.15

pyā-, pyä- motion hitherward, come. $16.27,20.12$ (twice), 36.33, 38.43, 38.45, 40.22, $40.23,40.28,64.1$

-pyä- quality, condition, water (idiomatically). 34.16

1 Possibly pemi- with $\mathrm{n}$ instrumental.

$147567^{\circ}-21-6$ 
pwāwi- fail, not; only rarely a pure verbal stem; usually used as a mere modal nega-

tive: see I. J. A. L., i, 54. 58.20

ma- (shortened form of mawi-) go. used only when the following stem begins with w.

64.43 (unless the combination mawâps is for mawi-āpA-)

mawi- go. ${ }^{1} 18.11,18.32,62.8,64.18,64.32$

mawi- wail over. 28.18

mä- move, chase, pursue; with -t-, ${ }^{\mathrm{d}}$ tci-. $\quad 32.40,32.42,42.26,56.7$

māto- worship, pray to. $16.29,24.4,40.32$

mānä- many. $20.10,32.16,42.14,60.24,60.42,62.32,62.33,62.40,64.21$

mānwi- many (evidently related to mānä). $52.40,62.9$

māwA- gather; with post-verbal extensions -t-, - dtci-. 28.44, 64.10

mA 'kAtäwi- black; fast (idiomatically). $34.32,36.12,38.11,38.24,66.2$

$\mathrm{mA}{ }^{\prime} \mathrm{kwā}-$ quiet; with -t-, - ${ }^{\mathrm{a}}$ tci- $16.24,38.20,44.18$

magi- big. $34.1,40.30$

mäne'ci- be ashamed. $60.3,60.9,60.11,60.13$

mane'sä- cut wood. 34.23

me'kwi- remember, recollect. $38.15,48.15,48.16$

me'c- capture. $60.42,60.43$

me'ci- large. 14.23

me'cki- open (of hands only); spread out (of objects). 30.11

me'cku- red. $14.12,32.35$

me'cw- shoot. $28.39,42.4$

me- bare, plain, open; with post-verbal -'t-, -'tci-. $30.1,32.31,32.33,38.43,48.7$,

$50.8,54.5,54.6,54.19$

me's- derive benefit from. 52.41

me'sōtäwi- all. $26.8,56.8$

mena- drink; in some way related to meno-. 32.2

meno- drink. $32.1,32.5$

menō'kami- spring (season). $14.7,36.12,56.28$

menwi- pleasant, good. $30.17,34.14,46.29,52.10,54.1,60.21,64.14$

-migA- an inanimate copula; goes with -migat-. $14.1,40.9$

-migat- an inanimate copula. 14.2, 18.40, 64.39

mī- give. 44.6, 58.13, 58.16

mi'ke ${ }^{\mathrm{d}}$ tci- doctor. $28.38,28.39,30.29,30.31,30.34$

mīgā- fight. 18.18, 20.12, 32.11, 42.3

mïcā- proud, glad, fine; with -t-, - ${ }^{\mathrm{d}}{ }^{\mathrm{t}} \mathrm{ci}$-. $\quad 16.27,28.31,42.24,58.3$

mïckawi- power (mystic). 30.39

mĩ tci- eat (with inan. object; or intrans.). $14.23,14.25,26.11,26.35,30.29,30.30$

minawi- attentive. 64.28

mō'ki- rush on, come out of suddenly. $32.27,62.31$

mōci have a vision of. 34.34

maiyō- weep, cry. $28.13,{ }^{2} 30.14,30.15,30.16,58.3,62.19,62.20$

myā- evil; with -n-, -'ci- (used with copulas -'si-, -et-). 40.8, 44.33, 44.34, 50.24, $52.9,54.3,56.35$

myā'ki- crippled. 20.14 (twice), $32.6,40.31$

-myä- back (substantival). $64.29,64.32$

wäga- whoop. $52.17,52.18$

wāt- beckon. 20.2

wā'sä- daylight. 14.4

WA ${ }^{d}$ tcā- cook for, prepare a meal for. $28.35,30.30,62.25,64.24,64.26$

wane'ckā- bad, immoral. 38.21, 38.22

1 Jones's mawi-.

2 Participial with "change.", 
wani- lose, fail. $36.43,46.6,58.22$

wapi- wrap. 48.9

wầgi- crooked. 32.9

wâ'si- cone (?). 18.7

wâpA- look at (with -m- -t- instr.). 38.35, 48.43, 64.43 (unless -âpA-; the case can not be settled with absolute certainty)

wâpA 'ci- funny (see wâpA's-). 44.16

wâps's- funny (see wâps'ci-). 42.4, 54.16.

wâpi- white. $16.15,34.2$

-wä- sound. $36.7,56.45$

wä'cī- paint. $14.12,14.15,14.20,14.21$

wädtci- easy (really wä- with -t-, - - ${ }^{\mathrm{d}}$ tci-). 60.26

wäpi- begin. $14.20,14.35,16.1,16.38,24.7,26.11,32.5,36.1,48.42,50.25,56.38$, $60.44,62.3,62.6,62.32,62.34,62.35,62.38$

-wäwä- sound ${ }^{1}$ (cf. -wä-) (with -'w- -'t- instr.). 20.37, 42.16, 58.21, 64.31

wäwen- (used with copulas -'si-, -et-) beautiful, fine. 46.26

we- lead, carry. $52.12,52.13,52.15,54.37,62.36$

-wi- an inanimate copula (rarely animate, but only apparently). 34.14, 54.13,

$58.10,64.28,64.29$

wi- with (with post-verbal -t-, $-{ }^{\mathrm{d}}$ tci-). $\quad 18.29,18.30,26.36,38.42,38.45,64.2164 .34$

wi- tell. $46.4,54.6,56.39$

wīkwä- bundle, wrap in blankets. $50.23,52.11$

wigi- excellent, good (of taste). 46.22

wigä- careful; with -t-, - ${ }^{\mathrm{d}}$ tci-. $44.21,58.39,58.40,58.41$

wi'cawi- terribly. 30.42

wīcāpenä- be hungry. 36.11

wïcigi- strongly, firmly. $38.11,42.15,42.43,56.18,58.19$ (twice), 58.20

wïck- meaning? hubbub? idiomatically always followed by -wäwä-. 64.31

wi'cku- sweet. $14.30,14.31,26.11,26.35$

wi'seni- eat, dine. $14.22,28.28,28.35,34.30$

winani- flay. 62.31

wi'pu- eat with (strictly wi- with -'pu- by the teeth). $26.36,26.37$ (twice)

1 A preceding i of a different morphological unit disappears before -wäwä-. 


\section{EXPLANATION OF PLATE 2}

1. The owl.

2. The pipe.

3 . The snapping turtle.

4. The tortoise.

5. The flute.

6. Earth.

7. Stone tongue.

8. The stone (used) when fire is made.

9. Those shot are cleaned where they were hit. [Appurtenance?]

10. Those celebrating the gens festival.

11. The speaker.

12. The drummer.

13. A singer.

14. Those celebrating the gens festival.

15. Old women.

16. Women.

17. Dancers.

18. A man.

19. A woman.

20. A man.

21. The sacred pack.

22. Fire.

23. Dancers. 


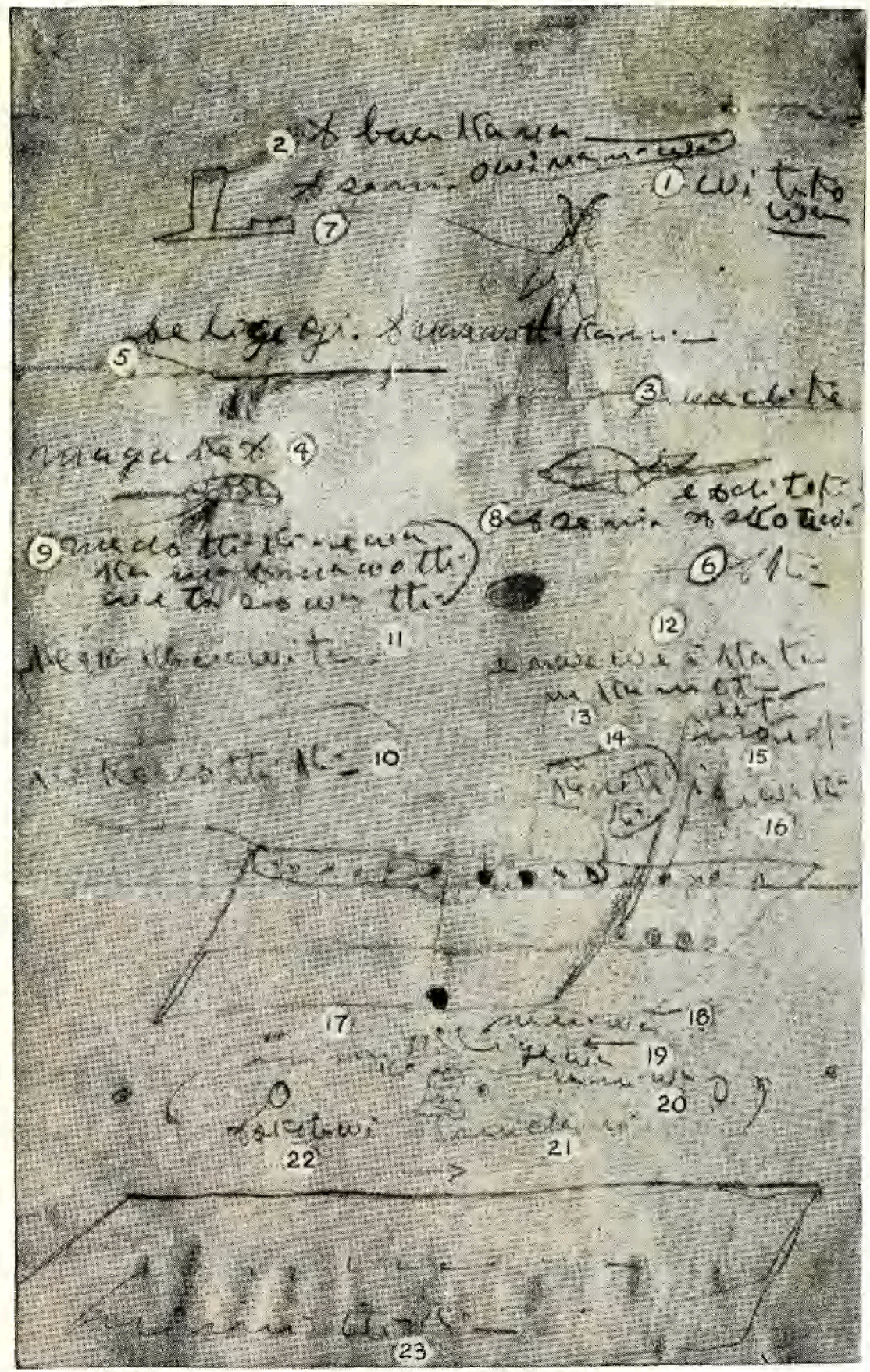

DIAGRAM SHOWING PERFORMANCE OF DANCE. DRAWN BY ALFRED KIYANA

The upper portion represents the contents of the Owl Sacrerl Pack. The lower portion is a diagram showing how the summer gons festival appurtenant 10. the Owl Sacred Pack is conducter in a bark house. 


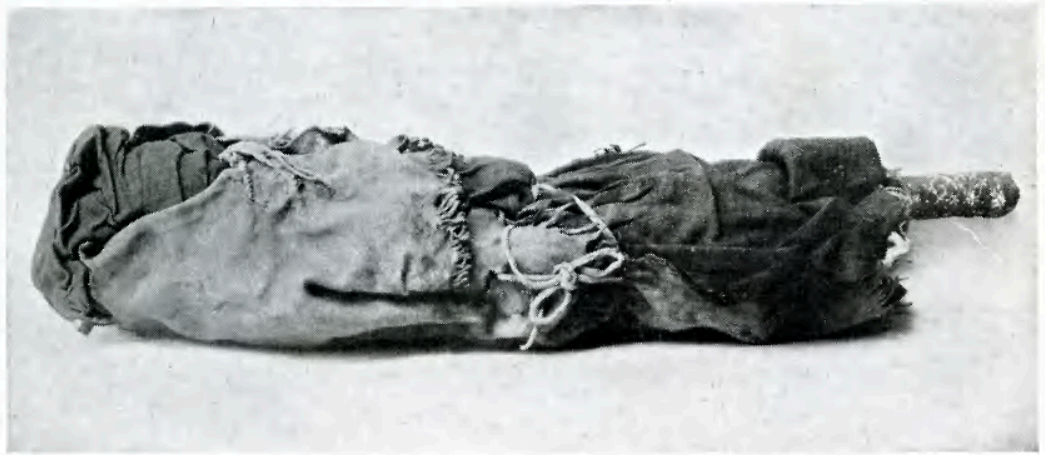

a. THE OWL SACRED PACK WITH THE OUTER WRAPPING OFF

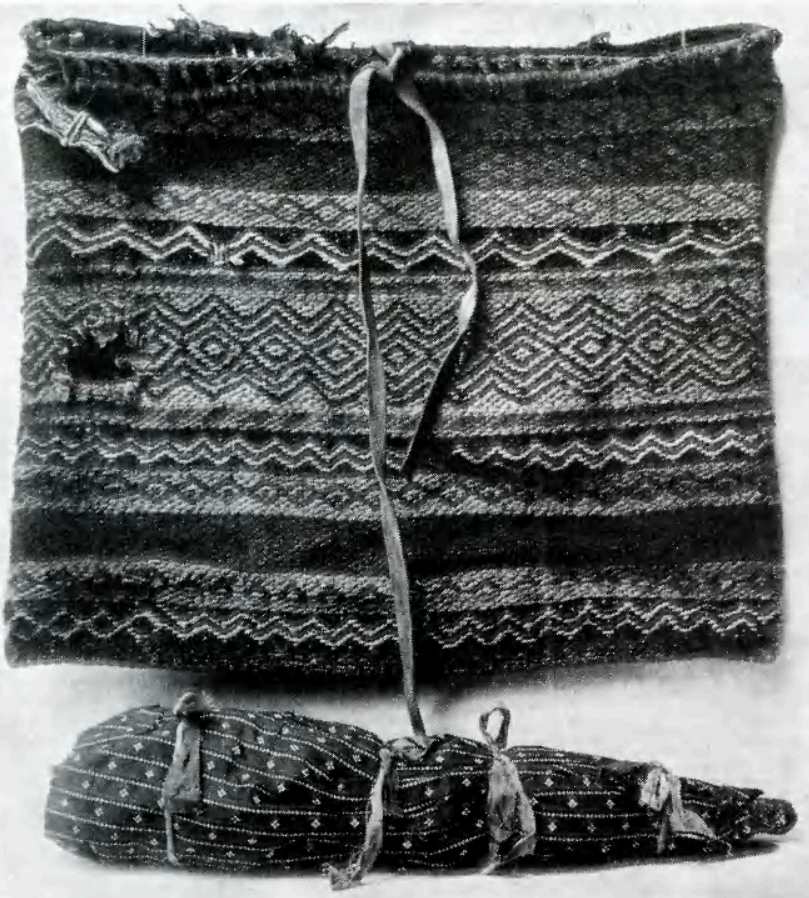

b. FIBER BAG IN WHICH THE OWL SACRED PACK WAS KEPT WRAPPINGS OF THE OWL SACRED PACK 

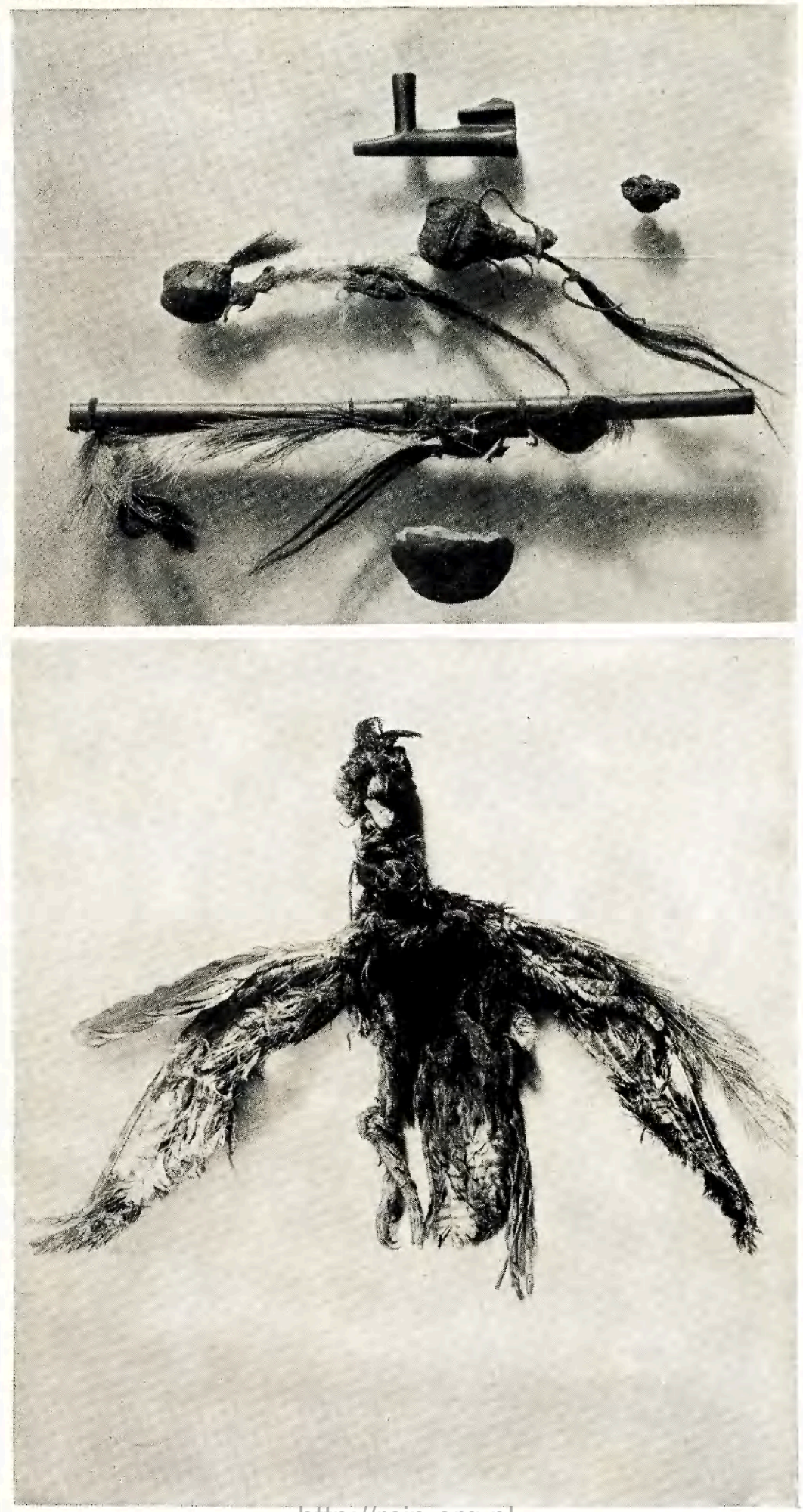


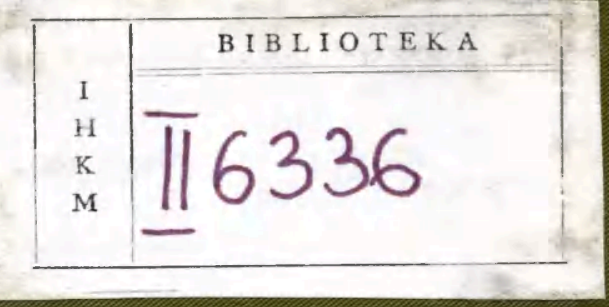

